Canadian Science Publishing

Canadian Journal of Earth Sciences Revue canadienne des sciences de la Terre

\title{
A missing link in the Peri-Gondwanan terrane collage: the Precambrian basement of the Moroccan Meseta and its lower Paleozoic cover
}

\begin{tabular}{|r|l|}
\hline Journal: & Canadian Journal of Earth Sciences \\
\hline Manuscript ID & cjes-2017-0086.R2 \\
\hline Danuscript Type: & Article \\
\hline $\begin{array}{r}\text { Complete List of Authors: } \\
\text { Is the invited manuscript for } \\
\text { consideration in a Special } \\
\text { Issue? : }\end{array}$ & $\begin{array}{l}\text { Letsch, Dominik; Institute for Geochemistry and Petrology, Earth Sciences } \\
\text { El Houicha, Mohamed; Université Chouaib Doukkali, El Jadida, Morocco } \\
\text { Winkler, Wilfried; Department of Earth Sciences ETH Zurich }\end{array}$ \\
\hline Keyword: & \\
\hline &
\end{tabular}

SCHOLARONE ${ }^{m}$

Manuscripts 
3

4

5

6

7

8

9

10

11

12

13

14

15

16

17

18

19

20 Institute of Geochemistry and Petrology, Department of Earth Sciences, ETH-Zentrum,

21 Clausiusstrasse 25, CH-8092 Zurich, Switzerland.

$22{ }^{2}$ Département de Géologie, Faculté des Sciences, Université Chouaib Doukkali, El Jadida, 23 Morocco.

$24{ }^{3}$ Geological Institute, Department of Earth Sciences, ETH-Zentrum, Sonneggstrasse 5, 8092

25 Zurich, Switzerland.

$26 \quad{ }^{4}$ Corresponding author: dletsch@ethz.ch

Clean version

\section{A missing link in the Peri-Gondwanan terrane collage: the Precambrian basement of the Moroccan Meseta and its lower Paleozoic cover}

Dominik Letsch ${ }^{1,4}$, Mohamed El Houicha ${ }^{2}$, Albrecht von Quadt ${ }^{1}$, Wilfried Winkler ${ }^{3}$ Final re-submission to the Canadian Journal of Earth Sciences 
27 Abstract

28 This article provides stratigraphic and geochronological data from a central part of 29 Gondwana's northern margin - the Moroccan Meseta Domain. This region, located to the 30 north of the Anti-Atlas area with extensive outcrops of Precambrian and lower Paleozoic 31 rocks, has hitherto not received much attention with regard to its Precambrian geology. 32 Detrital and volcanic zircon ages have been used to constrain sedimentary depositional ages 33 and crustal affinities of sedimentary source rocks in stratigraphic key sections. Based on this, 34 a four-step paleotectonic evolution of the Meseta Domain from the Ediacaran until the Early 35 Ordovician is proposed. This evolution documents the transition from a terrestrial volcanic 36 setting during the Ediacaran, to a short-lived carbonate platform setting during the early 37 Cambrian. The latter then evolved into a rifted margin with deposition of thick siliciclastic 38 successions in graben structures during the middle to late Cambrian. The detritus in these 39 basins was of local origin and a contribution from a broader source area (encompassing parts 40 of the West African Craton) can only be demonstrated for post-rifting i.e. laterally extensive 41 sandstone bodies that seal the former graben. In a broader paleotectonic context, it is 42 suggested that this Cambrian rifting is linked to the opening of the Rheic ocean, and that 43 several peri-Gondwanan terranes (Meguma and Cadomia/Iberia) may have been close to the 44 Meseta Domain before drifting, albeit some of them seem to have been constituted by a 45 distinctly different basement.

Key words: paleogeography - West African Craton - Peri-Gondwanan terrane - detrital 50 zircons - Cambrian 


\section{Introduction}

53

54

Shortly after the acceptance of the plate tectonics theory by the majority of geoscientists all over the world, the Canadian geologist Paul E. Schenk published a sweeping and thoughtprovoking paper in the Canadian Journal of Earth Sciences on the application of new global tectonics to the Precambrian and Paleozoic geological evolution of Northwest Africa and Atlantic Canada (Schenk 1971). Schenk's paper was based on Wilson's (1966) proposal that ocean basins may have opened and closed several times in Earth's history along similar lines and that the Atlantic Ocean might thus have had several precursors. Starting from the late Paleozoic Bullard-Choubert fit (see Kornprobst 2017 for a justification of that term) of the circum-Atlantic continents with North Africa (mainly Morocco) and Atlantic Canada (Newfoundland, Nova Scotia) and the northeastern USA adjacent to each other, Schenk suggested a high degree of tectonic mobility of small continental blocks (tectonic terranes avant la lettre) over several ocean-spreading-and-closing (Wilson) cycles. The eventual outcome of this prolonged history of spreading and collision was that "Africa has progressively lost increments of continental crust to North America.” (Schenk 1971, p. 1218). Interestingly, Schenk's reasoning had already been partially anticipated by Choubert (1935) who ascribed an "African" (i.e. Gondwanan) origin to parts of present-day northern America (namely Florida, see Letsch 2017).

Even though Schenk's approach was very schematic and geologically not particularly well founded (at least as far as Africa was concerned), and consequently not well received by geologists working in Morocco (Hollard and Schaer 1973), at least parts of his general message have been confirmed by later work. Reworked basement and cover relics, which are widely distributed over western Europe and eastern North America, preserve the traces of a common or at least very similar geological history during the Neoproterozoic and the early 
76 Cambrian (Murphy and Nance 1989, see Fig. 1). This history is generally linked to an

77 elongated and long-lasting subduction zone at the periphery of West Gondwana (West

78 African and Amazonian cratons), and the continental fragments which were later detached 79 from this active margin are variously referred to as Avalonian-Cadomian or peri-Gondwanan 80 terranes (e.g. Nance and Murphy 1994; Keppie et al. 2003; von Raumer et al. 2003;

81 Linnemann et al. 2008, or Garfunkel 2015). In pronounced contrast to the quickly growing 82 geochronologic database for many peri-Gondwanan terranes and the northern margin of the 83 West African Craton (i.e. the likely place of origin of these terranes), a small but central part 84 of the peri-Gondwanan collage - the Moroccan Meseta (Fig. 2) - has not received much 85 attention from a geochronological point of view until today (Dostal et al. 2005, Pereira et al. 86 2015, Ouabid et al. 2017). This is despite the fact, that a rich regional geologic history of the area is available in the literature (see e.g. Gigout 1951, Michard 1976, Piqué 2001, Hoepffner et al. 2005, Michard et al. 2008, 2010 for regional monographs and summary papers). It is the primary aim of the present paper to discuss the late Precambrian and early Paleozoic history of this missing link to which we will refer to as the Meseta Domain. This discussion is based on the interpretation of stratigraphic key sections and detrital and volcanic $\mathrm{U} / \mathrm{Pb}$ zircon ages. These are used for both constraining the depositional age of sedimentary successions and the crustal affinities of the rocks in the source areas providing the sedimentary detritus.

From a global paleogeographic perspective, the Meseta Domain is often viewed as the most external or peripheral part of Gondwana. It has supposedly not been detached as a periGondwanan terrane (but see e.g. Feinberg et al. 1990, von Raumer et al. 2003, Burkhard et al.

97 2006, or Stampfli et al. 2013 for a different view, assuming a highly mobile Meseta Domain 98 during parts of the Paleozoic) but was originally very close or even adjacent to these terranes. 99 Accordingly, it is supposed to have experienced a similar Neoproterozoic and Cambrian 100 geologic evolution (e.g. Linnemann et al. 2008, Waldron et al. 2009, Landing and 
101 MacGabhann 2010, or Nance et al. 2012). On the other hand, from the Northwest African

102 point of view, the Meseta Domain plays the role of a "northern continental block" for

103 Neoproterozoic ("Pan-African") plate reconstructions of the Anti-Atlas orogenic belt. In this

104 context, it supposedly collided in late Cryogenian times with the northern margin of the West

105 African Craton (Leblanc and Lancelot 1980) thereby closing an oceanic basin whose remains

106 are preserved in the Bou Azzer ophiolite (Leblanc 1976). The second aim of the paper is to

107 discuss the question whether the Meseta Domain represents a detached sliver of the West

108 African Craton (thus exhibiting Cadomian isotopic characteristics), or rather a basement block

109 (or blocks) of Avalonian affinity i.e. juvenile continental crust with mantle extraction and

110 magmatic crystallization ages of about $1000 \mathrm{Ma}$ (e.g. Nance et al. 2008). The latter has been

111 advocated by Pouclet et al. (2007) but contested by Landing (1996, Landing and MacGabhann

112 2010) and Dostal et al. (2005). Better knowledge of the late Proterozoic and early Palaeozoic

113 history of the Moroccan Meseta could furthermore shed new light on the question of the

114 paleogeographic provenance of the Meguma terrane of Nova Scotia. Schenk (1997) has

115 proposed tight stratigraphic connections between these two zones for Cambrian until

116 Devonian times (see also Stampfli et al. 2013). The new geochronological and stratigraphic

117 data presented in this article will allow to test proposed correlations among the Moroccan

118 Meseta, the Anti-Atlas, Cadomia, Avalonia and Meguma.

\section{Regional geological setting}

120 The Meseta Domain is divided from the Anti-Atlas Domain by a composite fault zone -

121 recently referred to as the South Meseta Fault Zone (SMFZ, Michard et al. 2010, Fig. 2) -

122 which runs across the High Atlas Belt, and is itself a much younger (Mesozoic to Cenozoic)

123 feature juxtaposed to an older geological structural fabric (see also Ouanaimi et al. 2016).

124 Nevertheless, the SMFZ approximately delineates the southern margin of a zone that

125 experienced intense late Paleozoic (Variscan) tectonic deformation and metamorphism 
126 coupled with abundant granitic intrusions (Mattauer et al. 1972, Hoepffner et al. 2005,

127 Michard et al. 2010). Due to this deformation and metamorphism, the original pre-Variscan

128 connections to the northern margin of the West African Craton (WAC), well preserved in the

129 Anti-Atlas belt, have been obscured. There is some debate on the relative positions of these

130 two tectonic provinces relative to each other during different periods of time. The continuity

131 of a glacial depositional systems is well-documented for the Ordovician (Le Heron et al.

132 2007) and thus excludes any later continental-scale movements between the two domains

133 (such as the ones proposed by von Raumer et al. 2003 or Stampfli et al. 2013). However, a

134 maximum of some $200 \mathrm{~km}$ of lateral displacement has been suggested e.g. by Mattauer et al.

135 (1972) but questioned by later workers on stratigraphic and structural grounds (Binot et al.

1361986 or Bernardin et al. 1988). In any case, the situation is different for the Neoproterozoic

137 and Cambrian. The Bou Azzer ophiolite of the Anti-Atlas (Leblanc 1976) and the relics of at

138 least one intraoceanic arc (Blein et al. 2014, Triantafyllou et al. 2016) along the Anti-Atlas

139 Major Fault (Fig. 2, the "Bou Azzer suture" on Fig. 1a), render it very plausible to assume at

140 least a small marginal ocean basin between the WAC (encompassing also most of the Anti-

141 Atlas) and the Meseta Domain (including the northern part of the Cenozoic High Atlas

142 Domain) during parts of the Cryogenian (e.g. Soulaimani et al. 2006, Bousquet et al. 2008).

143 However, there is also increasing evidence that the basement of the Meseta Domain

144 comprises ca. 2000 Ma basement of WAC affinity (Dostal et al. 2005, Pereira et al. 2015) and

145 consequently, the existence of a major ocean basin during the Neoproterozoic seems unlikely.

146 The situation might rather resemble an Alpine-type one with a narrow and rather short-lived

147 oceanic basin between two essentially similar continental areas. During the early and middle

148 Cambrian, both the Meseta and parts of the Anti-Atlas domains experienced strong rifting and

149 crustal thinning that lead to sediment-filled graben structures (Bernardin et al. 1988, see Fig.

150 2). In the northernmost part of the Anti-Atlas Domain (the Ouzellagh Massif, being located in

151 the present-day High Atlas), a serpentinized peridotite sliver smeared out along a younger 
152 fault and ophicalcite-pebble bearing conglomerate units (Pouclet et al. 2007) might

153 furthermore indicate strong crustal thinning and even mantle denudation (a hyper-extended

154 rifted margin, see e.g. Masini et al. 2013). Alternatively, they could also mark the

155 continuation of the Bou Azzer suture, otherwise covered by younger rocks, below the

156 Mesozoic to Cenozoic High Atlas Belt (implying an alternative placing of this suture as the

157 one suggested on Fig. 2 along the poorly understood Anti-Atlas Major Fault), or a

158 combination of both explanations might apply best. However, there is no field evidence for

159 any drifting between the Meseta Domain and the WAC during the early Paleozoic. On the

160 other hand, two (admittedly not so well constrained) apparent polar wander paths for the

161 Paleozoic of both the Meseta Domain and the northern margin of the WAC (including the

162 Anti-Atlas) seem to indicate a latitudinal difference of some $30^{\circ}$ between these domains

163 during the early Paleozoic (Feinberg et al., 1990). However, the findings of Feinberg et al.

164 (1990) were later contested by new paleomagnetic data from the Meseta Domain (Khattach et

165 al. 1995), that suggest that the two domains had been attached to each other since a least the

166 middle Cambrian.

167 Given the lack of good outcrops and the absence or sparseness of datable fossils in the few

168 Precambrian outcrops of the Meseta Domain, the late Precambrian and Cambrian stratigraphy

169 of the Anti-Atlas has traditionally been taken as a template to organize the scattered

170 observations in the former area (e.g. Gigout 1951, Michard 1976). However, there is still not

171 much geochronologic or paleontologic evidence available to corroborate these correlations

172 (Baudin et al. 2003, El Houicha et al. 2002), whereas there is increasing evidence for the

173 existence of a Paleoproterozoic basement beneath the Meseta Doman with WAC affinity

174 (Dostal et al. 2005, Michard et al. 2010, Pereira et al. 2015).

175 The Meseta Domain is divided into the Western and the Eastern Meseta which are 176 separated from each other by the Middle Atlas Belt (Fig. 2). For the present study, we have 
177 concentrated our efforts on the Western Meseta because Precambrian rocks are lacking in the

178 Eastern Meseta (but see Hoepffner et al. (2006) and Ouanaimi et al. (2016) for some

179 information on the early Paleozoic history of that area). The Western Meseta is divided into -

180 from East to West - the Nappe Zone (with gravitational sedimentary nappes of Variscan age),

181 the Central Zone, and the Coastal Block (Fig. 2). These zones have been affected to variable

182 degrees by late Paleozoic (Variscan) deformation, metamorphism and felsic intrusions with

183 the Coastal Block being the least affected. Interestingly, off-shore West Morocco,

184 orthopyroxene-bearing granodiorites (charnokites) have been dredged from the continental

185 rise (the Mazagan or El Jadida escarpment, Fig. 2), and have yielded whole rock and 186 quartz/feldspar fraction K/Ar ages of 900 to $1000 \mathrm{Ma}$ (Ruellan 1985). These ages, if they

187 indeed reveal real crystallization ages, would stand in contrast to the basement of the WAC

188 where such ages are absent, and hence could be taken as indication for basement relics of a 189 different provenance (Laurussia or Avalonia?) offshore the Meseta Domain. Notably, Tahiri 190 et al. (2010) suggested that the Sehoul Block just north of the Central Massif (Fig. 2) might

191 represent a fragment of Avalonia that became attached to the Meseta during a Late Devonian

192 to early Carboniferous collision following subduction of the Rheic ocean. In such a scenario,

193 the Mazagan escarpment might represent the lateral continuation of the Sehoul Block.

194 However, detrital zircon data from Cambrian sediments from the Sehoul Block do not support

195 an Avalonian origin (Pérez-Caceres et al. 2017), and the different degrees of metamorphic

196 overprint of both areas are further indications against such a correlation (Michard et al. 2010).

197 Basement outcrops and their immediate sedimentary cover in the Meseta Domain

198 There are only few locations in the Moroccan Meseta where basement can be safely 199 attributed to the Precambrian. Biostratigraphically meaningful fossils are lacking except for

200 some poorly preserved (and questionable) archaeocyathids mentioned by Morin (1962a).

201 Hence, early Cambrian and late Neoproterozoic ages have been inferred for these basement 
202 outliers and their immediate sedimentary cover through indirect arguments such as overlying 203 strata of supposedly Cambro-Ordovician age and comparison with the well-known 204 stratigraphy of the Anti-Atlas.

Precambrian outcrops in the Central Massif of the Central and Nappe zones (Fig. 2) occur as small basement inliers in the core of a large SW-NE trending anticlinorium of Variscan age 208 - the Zaïan anticlinorium - in the SE corner of the Central Massif (e.g. Morin 1960, 1962d, Michard 1976, Hoepffner et al. 2005, Michard et al. 2010). The metamorphic overprint is weak (upper greenschist facies at the highest, Bouabdelli 1994) and tectonic deformation is

211 concentrated within discrete zones. We have studied two sections in the southernmost tip of 212 the Central Massif close to the border to the Middle Atlas (between the cities of Khenifra and 213 Kasba Tadla, Figs. 4 and 5). For information on two other well-exposed sections nearby (Bou 214 Acila and Goaida), displaying a similar stratigraphy, we refer to Morin (1960, 1962c,d), 215 Michard (1976), Bouabdelli (1994), Michard et al.(2008). Recent petrographic, geochemical 216 and geochronological investigations have allowed Ouabid et al. (2017) to distinguish tree 217 distinct granitic rocks suites in the Goaida area. LA-ICP-MS dating of zircons from all three 218 suites yielded Ediacaran ages (625 $\pm 9 \mathrm{Ma}, 600 \pm 10 \mathrm{Ma}$, and $552 \pm 10 \mathrm{Ma})$.

The Jbel Hadid section starts with greenish-grayish schists displaying intense crenulation with some intercalated fine-grained magmatic rocks (unit 1 on Fig. 4a). Microscopically, some of the schists are made up of a fine-grained matrix composed of quartz, feldspar, sericite, and white mica with abundant angular grains of plagioclase and some quartz (Fig. 5c). They may partly represent deformed metarhyolites. Without any tectonic contact visible 224 in the field, these crenulated schists are followed by a unit comprising massive rhyolites, thick 225 breccia layers, and some subordinate mafic flows (unit 2, Fig. 4, 5d). Contrary to the 226 preceding unit, the rhyolites and sedimentary rocks of unit 2 display heterogeneous 
227 deformation with almost undeformed domains separated by mylonitic bands of some $10 \mathrm{~m}$ 228 thickness (see Bouabdelli 1994 for more details). Towards the top, the rhyolites decrease in 229 abundance and get eventually completely replaced by breccias. The latter range from coarse 230 to medium grained and contain pinkish-reddish rhyolite and feldspar/quartz fragments 231 floating in a dark green quartz-feldspar-sericite matrix. Locally, the top of this unit is 232 accompanied by lenses of quartz sandstone and intercalated deformed carbonate layers (unit 233 3, Fig. 4). The section is completed by a thick pile of grey shales with intercalations of 234 greywackes, basic flows and some quartz sandstone units (unit 4). Morin (1962b-d) correlated 235 the massive rhyolites and breccias of unit 2 with the "Précambrien III" (PIII) of the Anti-Atlas 236 (i.e. the Ediacaran Ouarzazate Group or Supergroup of the modern nomenclature, e.g. Thomas 237 et al. 2002) and the overlying shales with the middle Cambrian ("Paradoxides Shales").

238 The second section is located some $15 \mathrm{~km} \mathrm{SW}$ of the Jbel Hadid on a wide plain known as 239 Bou Ibenrhar (Figs. 2, 4b). It resembles the former section but tectonic repetitions cannot be 240 excluded based on local folding and faulting. We shall refer to the same lithostratigraphic 241 units as for the preceding section without thereby implying strict stratigraphic 242 correspondence. The base consists of phyllites and rhyolites (unit 2) that describe an upright 243 antiform whose southern limb is not preserved, but instead occupied by a steep tectonic fault 244 against crenulated phyllites of supposed Cambrian or Ordovician age (unit 5). The northern 245 limb exhibits a profile with basic to intermediate flows, breccias (Fig. 3d), and phyllites at the 246 base that are followed by a carbonate zone (unit 3) and again massive breccias. The 247 carbonates are mostly finely layered or even laminated, totally recrystallized and displaying 248 kink folding (Fig. 3a). However, there is a thin dolomite lens of some $50 \mathrm{~cm}$ thickness and 249 restricted lateral extent (at least some $10 \mathrm{~m}$ ) that preserves original textures and structures 250 such as e.g. symmetric ripple marks (Fig. 3b, sample 15DL3). Microscopically, the rock is a 251 grain- or packstone with abundant coated grains and carbonate intraclasts displaying a 
252 variable degree of recrystallization (Fig. 6). Different kinds of coated grains can be discerned 253 with sizes mostly ranging between 0.25 and $1 \mathrm{~mm}$, even though some grains can be much 254 larger (up to several $\mathrm{mm}$ ). Most common are spherical to slightly elliptical grains with 255 irregular, diffuse, and wrinkly laminations, which often form composite lumps of several 256 individual grains with irregular shapes (Fig. 6a). With increasing degree of recrystallization, 257 these grains pass to completely recrystallized elliptical grains composed of equant dolomite 258 crystals. Ooids with regular concentric lamination are rare. A second carbonate zone of 259 similarly deformed marbles, but without any preserved original textures, occurs above the 260 thick breccia unit. It is not clear whether one has to assume a tectonic contact between the two 261 units. The marble is covered by green metabasites with partly well-developed pillow 262 structures (Fig. 3c). The section ends with a thick stack of grey sandy shales with 263 intercalations of greywackes, some basic and intermediate lava flows, and very fine-grained 264 laminites of questionable volcanic origin (sample 15DL5). In its upper part, this unit contains 265 several quartz sandstone intercalations.

266 The western margin of the Central Zone provides even more restricted insights into the 267 Precambrian basement than the Central Massif. Tiny basement outcrops occur in the central 268 Rehamna Massif (Corsini et al. 1988, Baudin et al. 2003), where both tectonic deformation 269 and polyphase, partly intrusion-related, metamorphism are stronger, with the latter reaching 270 the amphibolite facies (Michard 1976, Hoepfner et al. 2005, Michard et al. 2008, 2010, 271 Chopin et al. 2014). Even though the local Paleozoic stratigraphy is still controversial, its 272 general outlines are fairly well established (Corsini et al. 1988, Baudin et al. 2003). In the 273 Sidi-Ali region (Fig. 2), a strongly tectonized fine-grained granite or rhyolite forms the core 274 of a small tectonic culmination - the Sidi Ali dome. It is covered by mica-rich 275 metaconglomerates/metabreccias (containing - among others - pebbles of fine-grained, 276 quartz-rich magmatic rocks with abundant tourmaline, Fig. 5e) and metarhyolites, which are 
277 capped by often laminated and recrystallized sandy carbonates. They are in turn covered by a 278 thick pile of grey shales with greywacke intercalations. The metarhyolite at the base has 279 yielded an U/Pb zircon SIMS (SHRIMP) age of $593 \mathrm{Ma}$ (Baudin et al. 2003).

The westernmost part of the Meseta Domain consists of a gently deformed and low-grade metamorphic block west of the highly deformed Central Zone. A rhyolite from the eastern margin of the coastal block (Sebt Brikyine, PP on Fig. 2) has yielded a Paleoproterozoic U/Pb zircon SIMS (SHRIMP) age (2045.1 $\pm 6.6 \mathrm{Ma}$, Pereira et al. 2015). Coastal outcrops next to the city of El Jadida (Gigout 1951), display a basal rhyolite of supposedly Neoproterozoic age which is covered by massive, gently folded, dolomites with breccia and sandstone intercalations at the base. The dolomites contain in their upper part several m-scale lenses of ooid/oncoid packstones (Fig. 3f). The latter are composed of variably shaped (although mostly circular to slightly ellipsoid) coated grains ranging from simple ooids, over multiple and broken ooids/oncoids to completely recrystallized microspar grains all embedded in a 291 microsparite to sparite matrix/cement (Fig. 6c,d). These grains range in size from less than 1 $292 \mathrm{~mm}$ to $3 \mathrm{~mm}$ diameter with the majority ranging between 2 and $3 \mathrm{~mm}$ and all grains display a 293 variable degree of recrystallization by randomly oriented dolomite crystals. This dolomite sequence is covered discordantly at El Jadida by Cretaceous carbonates. More towards the SE, in the nicely folded area around the water reservoir of Imfout, the supposed continuation of 296 the El Jadida section is represented by at least $3000 \mathrm{~m}$ of greenish-grey schists with sandstone 297 intercalations, which have yielded some trilobites (including Paradoxides, Gigout 1951). 298 These "Paradoxides Shales" grade upwards gradually into a 50 to $100 \mathrm{~m}$ thick sandstone 299 (partly feldspar-bearing) unit with two prominent, quartz-rich, marker horizons that can be 300 traced all over the Western Meseta and are referred to as the "El Hank Quartzite" or the "El 301 Hank Sandstone” (Michard 1976, Bernardin et al. 1988, Piqué 2001, Oukassou et al. 2017). It 
302 is often massive, but does frequently display cross bedding and even herringbone cross

303 stratification and hence points towards deposition in a shallow marine environment (André et

304 al. 1987, Oukkassou et al. 2017). Viewed under the microscope, the sandstone is very densely

305 packed, fine grained, and predominantly composed of rounded quartz grains with subordinate

306 microcline and some zircon grains. The quartz grains frequently exhibit sutured contacts (Fig.

307 5f).

$308 \mathbf{U} / \mathbf{P b}$ age dating

309 Methods and samples

310 The objective of the $\mathrm{U} / \mathrm{Pb}$ zircon age dating for the present study was twofold. Volcanic or

311 volcaniclastic rocks have been sampled in order to obtain approximate depositional ages of

312 their host rocks (see Supplementary Material 1 for sample localities). Clastic sedimentary

313 rocks have been sampled for detrital zircon age distributions. They reflect to a certain degree

314 the provenance of sedimentary detritus and the crustal affinity of the source areas.

315 Furthermore, the youngest detrital zircons define the maximum depositional age of a given

316 sample and can thus be used as older age brackets. Since individual zircon ages obtained by

317 low-precision in-situ $\mathrm{U} / \mathrm{Pb}$ age dating techniques can be misleading (Condon and Bowring

318 2011), we used the youngest graphical age peak of zircon age distributions as robust

319 maximum depositional ages (Dickinson and Gehrels 2009).

320 Rock samples ${ }^{1}$ of approximately $3 \mathrm{~kg}$ were fragmented using a high-voltage crushing

321 device (Selfrag $\mathrm{Lab}^{\mathrm{TM}}$ ). Zircons have been separated from the crushed rocks by means of

322 standard separation techniques and mounted in epoxy pellets. The internal structures of the

323 zircons have been imaged by cathodoluminescence (CL) and back-scattered electron (BSE)

324 methods using a TESCAN scanning electron microscope at the Department of Materials at

\footnotetext{
${ }^{1}$ Exact locations of sampling sites can be found in Supplementary Data 1. Supplementary data are available with the article through the journal web site at...
} 
325 ETH Zurich. Based on this information, suitable spots for $\mathrm{U} / \mathrm{Pb}$ dating were chosen. $\mathrm{U} / \mathrm{Pb}$ 326 geochronology was conducted by laser ablation inductively coupled plasma mass 327 spectrometry (LA-ICPMS) at the Institute of Geochemistry and Petrology, ETH Zurich. 328 Measuring and data reduction followed the ETH standard lab procedures described in detail 329 by e.g. Guillong et al. (2014). Analytical data are found in Supplementary Data 2. Only ages 330 with a degree of concordance, defined as $\left({ }^{206} \mathrm{~Pb}^{238} \mathrm{U}\right.$ age ${ }^{207} \mathrm{~Pb}-{ }^{235} \mathrm{U}$ age $) * 100$, between $95 \%$ 331 and $105 \%$ ) have been used for detrital zircon age spectra and volcanic age calculations. In the 332 case of volcanic rocks, supposed eruption ages have been calculated using the weighted mean 333 of ${ }^{206} \mathrm{~Pb} /{ }^{238} \mathrm{U}$ ages from certain zircon populations. Errors are reported to the $2 \sigma$ uncertainty 334 level.

335 Results

336 Sample 15DL1, taken from a rhyolite at the base of the Bou Ibenrhar succession (Fig. 4b) 337 only contained few zircons. From a total of 4 dated crystals, 3 concordant ages could be 338 obtained whose ${ }^{206} \mathrm{~Pb} /{ }^{238} \mathrm{U}$ ages overlap within error yielding a weighted mean age of $569.6 \pm$ $3393.8 \mathrm{Ma}(\mathrm{MSWD}=1$, see Supplementary Data 2 for graphic representations of data). Given the 340 small number of dated zircons and potential sources of inaccuracy and low precision inherent 341 in in-situ $\mathrm{U} / \mathrm{Pb}$ dating $(\mathrm{Pb}$ loss, moderate inheritance, even though CL-pictures did neither

342 reveal inherited cores nor where ages discordant), one should not attach too much significance 343 to this exact number; however, we think that it represents a general indication for the 344 emplacement age of this rhyolite and hence, also for the depositional age of the lower part of 345 the Bou Ibenrhar succession.

346 Sample 15DL6, an immature silty sandstone (greywacke) from the uppermost part of the 347 Bou Ibenrhar section (Fig. 4b) yielded 151 concordant ages with an extremely narrow 348 unimodal age distribution centering around $488 \mathrm{Ma}$ (Fig. 9). 
Sample 15DL9 represents a massive rhyolite from the central part of the Jbel Hadid section. From a total of 52 concordant ages (13 ages proved to be discordant) from 52 351 different grains (Fig. 8), 4 and 6 ages have been discarded from the beginning as being either 352 too young as judged from the overall geologic situation (presumably due to $\mathrm{Pb}$ loss) or too old (presumably xenocrysts or detrital zircons taken up by the ascending magma or later by the pyroclastic cloud or flow producing the rhyolite, respectively). The remaining 42 ages display considerable scatter and no clear age populations can be discerned. Based on visual inspection, we divided the "central" ages into two populations, that resulted in two weighted mean ${ }^{206} \mathrm{~Pb} /{ }^{238} \mathrm{U}$ ages $(563.8 \pm 3.6 \mathrm{Ma}$ and $597.4 \pm 2.7 \mathrm{Ma})$ with rather high MSWD values. Based on the better overlap of ages (reflected in a lower MSWD value) we interpret the second (older) value as being closer to the true crystallization age of this rhyolite and the younger age reflecting $\mathrm{Pb}$ loss. This inference is also borne out by other evidence as the zircons constituting the two age populations did neither differ in terms of crystal morphology 362 nor CL characteristics. Finally, the age of $597.4 \pm 2.7 \mathrm{Ma}$ fits well with the recently published $363 \mathrm{U} / \mathrm{Pb}$ zircon age of a granite form the nearby Goaida area (600 $\pm 10 \mathrm{Ma}$, Ouabid et al. 2017) 364 and both rocks might have had a common magmatic source.

Sample 15DL11 was taken from the matrix of a tourmaline-bearing metaconglomerate 366 from the Sidi Ali section (Fig. 5e). Somewhat similar to sample 15DL9, the few zircons 367 producing concordant ages (13 in total, with 5 ages being discordant, see Supplementary Data 3682 for graphic representations of data) display a diagonal age distribution on a weighted 369 average plot with few overlapping ages $\left({ }^{206} \mathrm{~Pb} /{ }^{238} \mathrm{U}\right.$ age range between ca. 548 and $\left.624 \mathrm{Ma}\right)$.

370 Our data alone does not allow to judge whether or not this age scatter is real and hence of 371 geological nature (as might be well the case for a clastic sediment), or simply due to analytical 372 uncertainty (similar grain morphologies and CL characteristics seem to point more likely to 373 the second possibility). However, granites ranging in age between 625 and 552 Ma have 
374 recently been reported from the Mesetan Central Massif (Ouabid et al. 2017) and hence we

375 propose these ages to be real and to indicate the existence of volcanic or magmatic rocks of

376 that age in the source area of the tourmaline-bearing metaconglomerate. By implication, the

377 latter's age would be younger than $548 \pm 6.4 \mathrm{Ma}$, but given the low number of analyzed

378 zircons we hesitate to attach too much weight to this maximum depositional age.

379 Sample 15DL12, a texturally mature quartz sandstone from the Imfout section yielded a 380 bimodal detrital zircon age distribution curve (Fig. 9). Apart from a rather narrow 381 Neoproterozoic peak (596 Ma), a smaller and broader Paleoproterozoic peak (2005 Ma) can 382 be discerned. Three isolated ages range between 900 and $1100 \mathrm{Ma}$.

\section{Discussion}

\section{Ediacaran and Cambrian evolution of the Meseta Domain}

Combining our new geochronologic data with the lithostratigraphic framework of the

387 Central and Western Meseta, we propose four evolutionary steps that are reflected by four 388 informal lithostratigraphic groups (Figs. 7 and 10).

389 Above a poorly known basement with affinities to the northern WAC (Pereira et al. 2015),

390 a widespread cover of continental clastic deposits with abundant interbedded silicic and 391 subordinate intermediate to basic volcanic rocks (Group I) was deposited during the 392 Ediacaran. Our $\mathrm{U} / \mathrm{Pb}$ zircon ages from two rhyolites $(597.4 \pm 2.6$ and $569.6 \pm 3.8 \mathrm{Ma})$ are in 393 general agreement with a similar rhyolite in the Rehamna (593 Ma, Baudin et al. 2003) and 394 tow recently dated granites in the Mesetan Central Massif $(600 \pm 10 \mathrm{Ma}$ and $552 \pm 10 \mathrm{Ma}$,

395 Ouabid et al. 2017). Abrupt lateral facies and thickness variations, sedimentary facies (locally 396 derived immature clastics), and the many rhyolite flows and ignimbrites are reasonably 
397 explained by a continental setting with pronounced topography and substantial paleotectonic 398 activity. A major time gap (ca. $1.5 \mathrm{Ga}$ ) between the Paleoproterozoic basement and the 399 Ediacaran terrestrial clastic and volcanic rocks can only be proved directly in the Central 400 Zone (Rehamna, Pereira et al. 2015). Elsewhere, the oldest exposed units are of 401 Neoproterozoic age or they could hitherto not be dated. The maximum depositional age of the 402 topmost part of Group I in the Rehamna area is poorly constrained by one zircon grain from 403 the matrix of a metaconglomerate yielding an $\mathrm{U} / \mathrm{Pb}$ age of $548 \pm 6.4 \mathrm{Ma}$.

404 Group I grades progressively upwards into a carbonate-dominated unit (Group II) which 405 can reach thicknesses of several hundred meters (Rehamna, Corsini et al. 1988). Due to 406 tectonic deformation and recrystallization, the original fabric of these carbonates is mostly 407 obliterated with the two exceptions in the El Jadida and Bou Ibenrhar sections (Fig. 6). The 408 grain/packstone microfacies of these rocks point towards deposition in agitated, shallow 409 water. The widespread distribution of Group II and the consistency of facies are best 410 explained by assuming a shallow continental platform setting. The lack of any fossils at the 411 localities studied hints towards a late Ediacaran or early Cambrian age which is in general 412 agreement with the late Ediacaran maximum depositional age of the top of the underlying 413 Group I.

414 The carbonates of Group II gradually develop into a thick clastic sequence dominated by 415 grey sandy shales with interbedded greywackes and abundant basic flows (the latter often 416 exhibiting pillow structures, Fig. 3c). This Group III, also referred to as "Schistes à 417 Paradoxides" (Paradoxides Shales) in the older literature (e.g. Gigout 1951), displays extreme 418 lateral thickness variations with the thickest parts being restricted to NNE-SSE trending 419 graben structures (Fig. 2, Bernardin et al. 1988) and it contains signs of basic volcanism at 420 many places (El Attari et al. 1997, Ouali et al. 2003, El Hadi et al. 2006). Hitherto considered 421 as being mostly of middle Cambrian (Gigout 1951), or early late Cambrian age (based on 
422 paleontologic evidence, Mergl et al. 1998), our new detrital zircon ages (Fig. 9a) rather 423 suggests a youngest Cambrian or even Early Ordovician age (at least in the southeastern 424 Central Massif). It should be mentioned here that this younger age assignment is in conflict 425 with existing paleontologic data from the overlying El Hank quartz sandstone in the area of 426 the Coastal Block pointing to a late Cambrian age for the latter. A possible solution to this 427 contradiction would be to assume that the lower part of the El Hank sandstone in the Coastal 428 Block area wedges out towards the east and is thus coeval with parts of the "Paradoxides 429 Shales" in the Central Zone of the Meseta (as indicated on Fig. 10). Be it as it may, the 430 extremely narrow zircon age distribution centering around $488 \mathrm{Ma}$ without any Precambrian 431 zircons has two important implications. First, there must have been a nearby source of 432 intermediate to felsic, youngest Cambrian volcanic rocks that are currently unknown in the 433 Moroccan Meseta Domain. This volcanism was likely related to the already well-known basic 434 volcanism associated with Group III and we propose that also the latter might be rather of late 435 than middle Cambrian age. Secondly, Group III sedimentary basins of the Mesetan Central 436 Massif were shielded at that time from any sedimentary detritus derived from older units of 437 the Meseta or from the Anti-Atlas area and the northern margin of the WAC. In accordance 438 with previous authors (e.g. Piqué 2001, 2003) we interpret the diverse graben structures that 439 received enormous amounts of locally derived detritus as the relics of a rifted continental 440 margin with an ocean finally developing west (with reference to present-day geography) of 441 the Meseta Domain. Shielding from sedimentary sources other than the immediate hinterland 442 of the rift basins may have been achieved by uplifted rift shoulders, a phenomenon which is 443 well-documented for e.g. the Mesozoic passive margins of Africa (Burke and Gunnell 2008).

444 A major paleogeographic shift is implied by the next higher Group IV, built of mature 445 quartz sandstones (with subordinate arkose sandstones) that blanket wide areas of the Meseta 446 with a remarkably constant thickness (the El Hank sandstone, e.g. André et al. 1987, Piqué 
447 2001). The El Hank sandstone is part of a much wider distributed composite basin that 448 developed during the Cambro-Ordovician all over present-day North Africa and the Middle 449 East (Burke et al. 2003), due to thermal subsidence of previously rifted continental 450 lithosphere. This inference is further corroborated by the detrital zircon age spectrum of 451 Group IV sandstones from the western margin of the Central Zone (sample 15DL12, Fig. 9b). 452 In strong contrast to the presumably only slightly older sample from the underlying rift453 related greywackes (Fig. 9a) the age spectrum displays a bimodal age distribution with a 454 major Ediacaran (596 Ma) and a minor Paleoproterozoic (ca. $2000 \mathrm{Ma}$ ) peak. This distribution 455 pattern is in general agreement with those of many other contemporaneous mature sandstones 456 from western North Africa and adjacent areas (e.g. Avigad et al. 2012, Meinhold et al. 2013) 457 and may thus be regarded as an integrated age signal of an extended source area. This does 458 likely not only encompass the Meseta Domain itself (where both age peaks could be identified 459 in the Precambrian basement, Pereira et al. 2015 and this paper) but also the peripheral areas 460 of the WAC (outcropping in the Anti-Atlas) where voluminous Neoproterozoic magmatism 461 and volcanism is well documented (e.g. Hefferan et al. 2014). It is noteworthy that the age 462 distribution of the El Hank sandstone is also very similar to that reported by Pérez-Caceres et 463 al. (2017) from the middle (?) Cambrian sandstones from the Sehoul Block in the northern 464 part of the Meseta Domain (Fig. 2).

The Meseta Domain and the Anti-Atlas

As pointed out previously, the Anti-Atlas area is a natural candidate for a comparison with 467 the Meseta Domain. However, it should be noted that a direct comparison between the Meseta 468 Domain and the Anti-Atlas is severely hampered by the very different quality of Precambrian 469 and early Paleozoic outcrops in the two areas. Whereas in the former only tiny inliers allow a 470 very restricted view of the whole story, rocks of that age form marvelous outcrops of wide 471 extent in the latter. Despite these shortcomings, many striking similarities can be seen. The 
472 Proterozoic basement (dominated by voluminous ca. $2000 \mathrm{Ma}$ intrusions) is observed in both

473 regions. However, the complicated pre-Ediacaran geological record of the Anti-Atlas (with

474 extensive Proterozoic quartz sandstones, greywackes, ophiolites, or intraoceanic arc relics)

475 has no present-day counterpart in the Meseta Domain. The widespread Ediacaran terrestrial

476 clastic and volcanic rocks (our Group I), on the other hand, correlates very well both in terms

477 of facies and age with the Ouarzazate Supergroup (Thomas et al. 2002, corresponding to PIII

478 of older authors) of the Anti-Atlas (as already suspected by e.g. Morin 1962). Less straight

479 forward is the correlation between the Meseta carbonate rocks (our Group II) and the

480 carbonate-dominated late Neoproterozoic to early Cambrian Taroudant and Tata Groups of 481 the Anti-Atlas (e.g. Geyer and Landing 1995, Alvaro et al. 2014). The classically evoked 482 correlation with the Adoudou Formation (the base of the Taroudant Group) would explain the 483 lack of fossils in our Group II, but the sedimentary facies of the two are quite different. 484 Grainstones of the type encountered at El Jadida and Bou Ibenrhar are lacking in the Adoudou 485 dolomites and the stromatolites so abundant in the latter seem to be missing in the Meseta 486 Domain. In the Anti-Atlas, similar grainstones only occur in the upper part of the early 487 Cambrian (Igoudine and Amouslek formations) together with first larger shelly fossils 488 (trilobites and archaeocyathids). Despite the lack of the latter in the Meseta (with the 489 exception of the Jebilet in its southern part, see e.g. Michard 1976), we tentatively assume a 490 late early Cambrian age for our Group II (see also El Houicha et al. 2002). The overlying 491 sandy shales with greywackes (our Group III) have traditionally been correlated with the 492 trilobite-rich "Schistes à Paradoxides" of the Anti-Atlas (the Jbel Wawrmast Formation of 493 Geyer and Landing 1995). Based on our new detrital zircon age dating with a narrow age peak 494 around $488 \mathrm{Ma}$ (i.e. youngest Cambrian) we discard this correlation at least for this parts of 495 Group III which has been looked at for the present study. The Wawrmast Formation, on the 496 other hand, which has been ascribed an early Tissafinian age (middle Cambrian, around 511 497 Ma according to Landing et al. 1998) based on fossils, contains K-bentonites and mafic flows 
498 in the High Atlas and parts of the Anti-Atlas (Geyer and Landing 1995) that have so far not 499 been dated radiometrically. The capping sandstones constituting our Group IV (El Hank 500 Sandstone) can feasibly be correlated with the arenitic upper Cambrian Tabanite Group 501 (Geyer and Landing 1995) of the Anti-Atlas, that exhibits similar, though not identical, 502 detrital zircon age distribution patterns (Avigad et al. 2012). The Tabanite Group in the 503 eastern Anti-Atlas area contains and is covered by basic to intermediate volcanics (Baidder et 504 al. 2008), which could potentially be the expression of the same magmatic activity as the one 505 recorded in the Meseta Domain. Finally, the occurrence of Early Ordovician red-beds, filling 506 graben structures, in the northernmost Anti-Atlas Domain (Ouanaimi et al. 2016) deserves 507 attention. Given our new age data, a temporal correlation between these red beds and the 508 upper part of the "Schistes à Paradoxides" of the Central Massif seems not unreasonable.

In terms of paleotectonic considerations, the foregoing discussion can be summarized as

510 follows. Both the Meseta Domain and the Anti-Atlas include a Paleoproterozoic basement 511 with strong affinities to the WAC. The Meseta Domain and Anti-Atlas records appear 512 different for the Cryogenian because the Meseta does not contain the lithologies and 513 deformations evident in the Anti-Atlas for this time period. However, both records preserve 514 evidence for a tectonically active intracontinental setting with abundant, mostly acidic, 515 magmatic activity. The Meseta Domain and Anti-Atlas document a similar Cambrian history 516 with large-scale rifting which is also, albeit not so prominently, seen in the Anti-Atlas (Piqué 517 2001, El Archi et al. 2004). These interpretations are consistent with recent paleotectonic 518 models, which assume collision between the WAC's northern margin (Anti-Atlas), an intra519 oceanic arc and finally a northern continental block (the Meseta) during the late Cryogenian 520 with subsequent post-collisional intra-continental rifting and/or strike-slip deformation (e.g. 521 Hefferan et al. 2014). 
Schenk (1971) proposed that the Meseta Domain had great lateral mobility during the early

524 Paleozoic (see also Feinberg et al. 1990, von Raumer et al. 2003, Burkhard et al. 2006, or

525 Stampfli et al. 2013). Despite the fact that a one-to-one correlation between the Anti-Atlas

526 and the Meseta Domain is not always possible (which is not surprising if one takes into

527 consideration the lateral distance between the two areas and the facies changes observed

528 within the two units), the general similarities of their late Neoproterozoic and Cambrian

529 geologic histories is striking but explainable by assuming a Cryogeneian collision between the

530 two blocks (see above). The lack of pre-Ediacaran marine strata in the Meseta Domain might

531 be rationalized by hypothesizing that the Meseta Domain was in an upper plate position.

532 However, a correlation, or even an identification between the Meseta Domain and the

533 Avalonian terrane (as e.g. suggested by Pouclet et al. 2007, Gasquet et al. 2008) seems

534 difficult for several reasons:

535

536

537

538

539

540

541

542

543

544

- Sedimentary facies. Whereas Avalonia's Neoproterozoic to early Paleozoic record is practically devoid of any shallow-water carbonates (Landing 1996), Cambrian carbonates (partly still preserving grainstone facies) are a common feature of the Moroccan Meseta. Furthermore, contrary to the Avalonian terrane (e.g. Keppie et al. 1991, Landing 1996, Murphy et al. 2013), no Ediacaran or older marine sedimentary rocks (rich in volcanic detritus) have yet been identified in the Meseta Domain.

- No Neoproterozoic volcanic arc. The Meseta Domain does not contain any direct or indirect (as e.g. detrital zircons) evidence for the development of an oceanic or a continental arc during the Cryogenian or the Ediacaran (unless one would interpret our Group I as the expression of Ediacaran arc magmatism in an Andean-type setting, as it has indeed been proposed by Tahiri et al. (2010) for the northern Meseta, or Walsh et al. (2012) for the similar Ouarzazate Supergroup of the Anti- 
Atlas). This is in contrast to the Avalonian Terrane, where volcanic arc volcanism and are-related sedimentation is well-documented (e.g. Murphy et al. 2013).

- Basement. Whereas for Avalon a juvenile ca. $1000 \mathrm{Ma}$ basement is well-established (Nance et al. 2002), no basement relics of that age have so far been found in the Meseta Domain with the exception of the questionable occurrence in the offshore Mazagan escarpment (see Fig. 2) whose direct link to the Meseta is not wellestablished.

- Detrital zircons. Our detrital zircon age data display a prominent lack of Mesoproterozoic ages (1200 to $1700 \mathrm{Ma}$ ). This feature has been identified by Garfunkel (2015) as being quite typical for sedimentary rocks from Cadomiaderived blocks but not for Avalonia-derived blocks.

Hence, a correlation between the Meseta Domain and Avalonia has many difficulties (see also Khattach et al. 1995 for paleomagnetic arguments) and also a correlation with Cadomia (see e.g. Fig. 10) cannot be achieved in a straight-forward manner due to different sedimentary facies and the absence of any arc-related rocks in the Meseta (even though both terranes display similar basement and detrital zircon ages). The terrane configuration suggested in Fig. 1 can principally account for these differences, because both Cadomia and Avalonia are in a more proximal position with regard to the suggested late Neoproterozoic subduction zone and arc magmatism may not have reached as far as to the Meseta Domain (schematically depicted in Fig. 10a).

However, whereas these differences mainly center on the Neoproterozoic and early Cambrian development, there is some agreement between the geological evolution of the Meseta Domain, the Meguma terrane of Nova Scotia, and certain supposedly Gondwanaderived fragments in Western Europe during the later Cambrian and Early Ordovician. Starting with Meguma, both areas (Meguma and Meseta Domain) document late Cambrian 
573 rifting with thick siliciclastic graben fills and locally derived detrital zircons (Keppie et al.

574 1991, Schenk 1996). Published detrital zircon records from Meguma (Waldron et al. 2009)

575 resemble our new data (Fig. 9) in several respects: (i) a Mesoproterozoic gap or at least a

576 rarity of ages, (ii) important Ediacaran peaks, (iii) few Cryogenian ages, and (iv) a ca. 2000

577 Ma contribution (not in all samples). However, the important, albeit, according to present

578 knowledge, geographically restricted, late Cambrian contribution (488 Ma) does not exist in

579 Meguma. Thus it seems rather likely to assume a certain proximity between the Meguma

580 terrane and the Meseta Domain, at least during the late Cambrian and Early Ordovician (as

581 already suspected by Schenk 1971).

582 Seen from a broader paleotectonic perspective, this common Meguma and Meseta history

583 fits well with the opening of the Rheic ocean in the late Cambrian and Early Ordovician

584 (Nance et al. 2012) and perhaps the Meseta Domain, and the Meguma terrane tell the same

585 story albeit from the two different sides of the evolving Rheic ocean (see also Marzoli et al.

586 2017). Such a proximity of the Meseta Domain and Meguma is also suggested by the plate

587 reconstruction of von Raumer et al. (2003). However, given the supposed close connections

588 between Meguma and Avalonia during the entire Paleozoic (Murphy et al. 2004), such a

589 conjecture creates new difficulties for the early Paleozoic position of Avalonia since Landing

590 (1996, see also Landing and MacGabhann 2010) has provided convincing evidence for an

591 isolated position of the latter terrane at the end of the Ediacaran. It is beyond the scope of the

592 present paper to discuss these matters further, but we suggest that the Meseta Domain might

593 provide a missing link between Gondwana (the West African Craton) and Meguma, which

594 would strengthen the link between the latter two domains (advocated by Schenk 1971, 1996).

595 With regard to European basement fragments of supposed Gondwana-origin, we point out that

596 late Cambrian to Early Ordovician felsic magmatism (hitherto unknown from Morocco but

597 suggested by zircon ages from our sample 15DL6, Fig. 9a) is a well-known feature in several 
598 areas of Cadomian and Iberian origin. Striking examples are provided by the pre-Mesozoic

599 basement of the Alps (von Raumer et al. 2013), or the Tras-os-Montes Zone of central and

600 NW Iberia (Talavera et al. 2013). In analogy with Meguma, this coincidence in late

601 Cambrian/Early Ordovician magmatism could be explained by assuming that both Cadomia

602 and Iberia were close to the Meseta Domain at that time and later detached from this part of

603 Gondwana's margin as a consequence of the opening of the Rheic ocean.

604

605 Conclusions

606 - The Moroccan Meseta Domain shares many similarities with the much better

607 known Anti-Atlas area with regard to basement (2000 Ma) and post-Cryogenian

608 geologic development implying that the two areas have been closely together ever

609 since at least the early Ediacaran.

610 - Differences with the Anti-Atlas area with regard to the Cryogenian geological

611 evolution can be explained by invoking an intervening oceanic basin developing

612 during the Cryogenian with subsequent closure and collision between the two

613 blocks. This ocean shielded the Meseta Domain from receiving abundant sandy

614 detritus from the WAC prior to the dawn of the Phanerozoic, which explains the

615 absence of massive and thick Proterozoic quartz sandstone bodies that are typical of

616 the Anti-Atlas area.

617 - Correlations between the Meseta Domain and several peri-Gondwanan terranes

618 (Avalonia, Cadomia) are difficult, due to different sedimentary facies and the lack

619 of convincing evidence for a Neoproterozoic volcanic arc in the Meseta Domain.

620 This is probably due to a more distal position of the Meseta Domain with regard to

621 the laterally very extended Neoproterozoic subduction zone invoked for many peri- 
Gondwanan terranes. However, despite these differences a proximity among these different terranes does not seem implausible, and a possible Ediacaran setting is suggested in Fig. 10a.

- During the late Cambrian and Early Ordovician, the western Meseta Domain developed to a rifted margin presumably bordering the evolving Rheic ocean. Close stratigraphic resemblances and similar detrital zircon age distributions suggest that the Canadian Meguma terrane, Cadomia, and Iberia might have been in close proximity to the Meseta Domain during the late Cambrian albeit, on the other side of the evolving Rheic ocean and comprising partly different basement. The geology of the Meseta Domain, however, does not allow us to conclude whether or not this proximity was exclusively an early Paleozoic feature (caused e.g. by a collision between Cadomia/Meguma and the Meseta) or was already established during the Neoproterozoic.

\section{Acknowledgements}

The authors thank Mohamed Kanite for invaluable help in the field and Mohamed Ait Bahassou and Brahim Ait Moussa for organizing the logistics of our fieldwork in Morocco. Furthermore, we acknowledge Katja Rutz for her help with mineral separation and producing CL images, Marcel Guillong and Oscar Laurent for help with the laser ablation work, Remy Lüchinger for preparing thin sections, and Peter Nievergelt for his constant advice on thin section interpretation. Constructive comments by André Michard, an anonymous reviewer, and associate editor Luke Beranek helped substantially to improve an earlier version of this publication. This study has been made possible by Swiss National Science Foundation grant 156244. 
646

647

648

649

650

651

652

653

654

655

656

657

658

659

660

661

662

663

664

665

666

667

\section{References cited}

Alvaro, J.J., Benziane F., Thomas, R., Walsh, G.J., Yazidi, A. 2014. Neoproterozoic-

$$
\text { Cambrian stratigraphic framework of the Anti-Atlas and Ouzellagh promontory (High }
$$

Atlas), Morocco. Journal of African Earth Sciences, 98: 19-33.

André, J.-P., Boissin, J.-P., Corsini, M., and Renard, J.-P. 1987. Sur le Cambrien de la région de Casablanca (Maroc): la série de Dar Bou Azza. Bulletin Société géologique de France, III/6: 1161-1170.

Avigad, D., Gerdes, A., Morag, N., Bechstädt, T. 2012. Coupled U-Pb-Hf of detrital zircons of Cambrian sandstones from Morocco and Sardinia: implications for provenance and Precambrian crustal evolution of North Africa. Gondwana Research, 21: 690-703.

Baidder, L., Raddi, Y., Tahiri, M., Michard, A. 2008. Devonian extension of the Pan-African crust north of the West African craton, and its bearing on the Variscan foreland deformation: evidence from eastern Anti-Atlas (Morocco). Geological Society, London, Special Publications, 297: 453-465.

Baudin, T., Chévrement P., Razin, P., Youbi, N., Andries, D., Hoepffner C., Thiéblement, D., Chihani, E., Tegyey, M. 2003. Carte géologique du Maroc au 1/50’000, feuille de Skhour des Rehamna. Mémoire explicative. Notes Mémoires Service Géologique du Maroc, 435: $1-114$

Bernardin, C., Cornée, J.-J., Corsini, M., Mayol, S., Muller, J., and Tayebi, M. 1988.

Variations d'épaisseur du Cambrien moyen en Meseta marocaine occidentale: signification géodynamique des données de surface et de subsurface. Canadian Journal of Earth Sciences, 25: 2104-2117. 
668 Binot, F., Dresen, G., Stets, J., and Wurster, P. 1986. Die Tizi-n’Test-Verwerfungszone im 669 Hohen Atlas (Marokko). Geologische Rundschau, 75/3: 647-664.

670 Blein, O., Baudin, T., Soulaimani, A., Cocherie, A., Chèvrement, P., Admou, H., Ouanaimi, 671 H., Hafid, A., Razin, P., Bouabdelli, M., Roger, J. 2014. New geochemical, 672 geochronological and structural constraints on the Ediacaran evolution of the south Sirwa, 673 Agadir-Melloul and Iguerda inliers, Anti-Atlas, Morocco. Journal of African Earth $674 \quad$ Sciences, 98: 47-71.

675 Bouabdelli, M. 1994. Tectonique de l'Est du Massif hercynien central (zone d'Azrou676 Khénifra). Bulletin Institute des Sciences, Rabat, 18: 145-168.

677 Bousquet, R., El Mamoun, R., Saddiqi, O., Goffé, B., Möller, A., Madi, A. 2008. Mélanges 678 and ophiolites during the Pan-African orogeny : the case of the Bou-Azzer ophiolite suite 679 (Morocco). Geological Society, London, Special Publications, 297: 233-247.

680 Burke, K., Gunnell, Y. 2008. The African erosion surface: a continental-scale synthesis of 681 geomorphology, tectonics, and environmental change over the past 180 million years. The 682 Geological Society of America Memoir, 201: 1- 66.

683 Burke, K., Macgregor, D.S., Cameron, N.R. 2003. Africa’s petroleum systems: four tectonic 684 "Aces" in the past 600 million years. Geological Society, London, Special Publications, 685 207: $21-60$.

686 Burkhard, M., Caritg, S., Helg, U., Robert-Charrue, C., Soulaimani, A. 2006. Tectonics of the 687 Anti-Atlas of Morocco. C.R. Geoscience, 338: 11-24.

688 Chopin, F., Corsini, M., Schulmann, K., El Houicha, M., Ghienne, J.-F., Edel, J.-B. 2014.

689 Tectonic evolution of the Rehamna metamorphic dome (Morocco) in the context of the 690 Alleghanian-Variscan orogeny. Tectonics, 10.1002/2014TC003539. 
691 Choubert, B. 1935. Recherches sur la genèse des chaînes paléozoïques et antécambriennes.

692 Rev. Géographie Phys. Géol. Dynamique, VIII 1: 5-50.

693 Condon, D.J., Bowring, S.A. 2011. A user's guide to Neoproterozoic geochronology.

694 Geological Society, London, Memoirs, 36: 135-149.

695 Corsini, M., Muller, J., Cornée J.-J., Diot, H. 1988. Découverte de la série basale du Cambrien

696 et de son substratum dans les Rehamna centraux, haut-fond au Cambrien (Méséta

697 marocaine). Prémices de l'orogenèse hercynienne. Comptes rendus de l'académie des

698 sciences Paris, $306: 63-68$.

699 Dickinson, W.R., Gehrels, G.E. 2009. Use of U-Pb ages of detrital zircons to infer maximum 700 depositional ages of strata: a test against a Colorado Plateau Mesozoic database. Earth and $701 \quad$ Planetary Science Letters, 288: 115-125.

702 Dostal, J., Keppie, J.D., Hamilton, M.A., Aarab, E.M., LeFort, J.P., Murphy, J.B. 2005.

703 Crustal xenoliths in Triassic lamprophyre dykes in western Morocco: tectonic implications 704 for the Rheic Ocean suture. Geological Magazine, 142: 159-172.

705 El Archi, A., El Houicha, M., Jouhari, A., and Bouabdelli, M. 2004. Is the Cambrian basin of 706 the Western High Atlas (Morocco) related either to a subduction zone or a major shear 707 zone? Journal of African Earth Sciences, 39: 311-318.

708 El Attari, A., Hoepffner, C., Jouhari, A. 1997. Nouvelles données magmatiques et structurales 709 en relation avec la cinématique de l'ouverture du bassin cambrien de la Méseta $710 \quad$ Occidentale (Maroc). Gaia, 14: 11-21.

711 El Hadi, Tahiri, A., Simancas Cabrera, F., Gonzalez Lodeiro, F., Pérez, A.A., Martinez 712 Poyatos, D.J. 2006. Un exemple de volcanisme calco-alcalin de type orogénique mis en 
713 place en contexte de rifting (Cambrien de l'oued Rhebar, Meseta occidentale, Maroc). C.R.

714 Geoscience, 338: 229-236.

715 El Houicha, M., Elicki, O., Jouhari, A., Bouabdelli, M. 2002. Les calcaires marmorisés

716 cambriens de la zone orientale du Massif hercynien central marocain: nouvelles données

717 biostratigraphiques et sédimentologiques. 19th Colloquium of African Geology, EI

718 Jadida, Morocco. 19-22 March 2002: 79.

719 Feinberg, Aifa, T., A., Pozzi, J.-P., Khattach, D., and Boulin, J. 1990. Courbes de dérive

720 apparente des poles magnétiques de l'Afrique et de la Méséta marocaine pendant le

721 Paléozoique. Comptes rendus de l'académie des sciences Paris, 310/II : 913-918.

722 Garfunkel, Z. 2015. The relations between Gondwana and the adjacent peripheral Cadomian

723 domain - constraints on the origin, history, and paleogeography of the peripheral domain.

724 Gondwana Research, 28: 1257-1281.

725 Geyer, G., Landing, E. 1995. The Cambrian of the Moroccan Atlas regions. Beringeria, 726 Special Issue, 2: 7-46.

727 Gigout, M. 1951. Études géologiques sur la Méséta marocaine occidentale (arrière-pays de 728 Casablanca, Mazagan et Safi. Travaux de l'Institute Scientifique chérifien, 3: 1-507.

729 Guillong, M., von Quadt, A., Sakata, S., Peytcheva, I., Bachmann, O. 2014. LA-ICP-MS pb-

730 U dating of young zircons from the Kos-Nisyros volcanic centre, SE Aegean arc. Journal 731 of Analytical Atomic Spectrometry, 29: 963-970.

732 Hefferan, K., Soulaimani, A., Samson, S.D., Admou, H., Inglis, J., Saquaque, A., Latifa, C., 733 Heywood, N. 2014. A reconsideration of Pan African orogenic cycle in the Anti-Atlas 734 Mountains, Morocco. Journal of African Earth Sciences, 98: 34-46. 
735 Hoepffner, C., Soulaimani, A., Piqué, A. 2005. The Moroccan Hercynides. Journal of African $736 \quad$ Earth Sciences, 43: 144-165.

737 Hoepffner, C., Houari, M.R., Bouabdelli, M. 2006. Tectonics of the North African Variscides 738 (Morocco, western Algeria): an outline. Comptes-Rendu Geosciences, 338: 25-40.

739 Hollard, H., and Schaer, J.P. 1973. Southeastern Atlantic Canada, Northwestern Africa, and 740 Continental drift: discussion. Canadian Journal of Earth Sciences, 10: 584-586.

741 Keppie, J.D., Nance, R.D., Murphy, J.B., Dostal, J. 1991. Northern Appalachians: Avalon and 742 Meguma terranes. In The West African orogens and circum-Atlantic correlatives. Edited 743 by R.D. Dallmeyer \& J.P. Lécorché. Springer, Berlin, pp. 315-333.

744 Keppie, J.D., Nance, R.D., Murphy, J.B., Dostal, J. 2003. Tethyan, Mediterranean, and Pacific 745 analogues for the Neoproterozoic birth and development of peri-Gondwanan terranes and 746 their transfer to Laurentia and Laurussia. Tectonophysics, 365: 195-219.

747 Khattach, D., Robardet, M., Perroud, H. 1995. A Cambrian pole for the Moroccan Coastal 748 Meseta. Geophysical Journal International, 120: 132-144.

749 Kornprobst, J. 2017. Boris Choubert: the forgotten fit of the circum-Atlantic continents. $750 \quad$ Comptes Rendus Geoscience, 349: 42-48.

751 Landing, E. 1996. Avalon: insular continent by the latest Precambrian. Geological Society of $752 \quad$ America Special Paper, 304: 29-63.

753 Landing, E., Bowring, S., Davidek, K.L., Westrop, S.R., Geyer, G., Heldmaier, W. 1998.

754 Duration of the Early Cambrian: U-Pb ages of volcanic ashes from Avalon and Gondwana. 755 Canadian Journal of Earth Sciences, 35: 329-338. 
756 Landing, E., and MacGabhann, B.A. 2010. First evidence for Cambrian glaciation provided

757 by sections in Avalonian New Brunswick and Ireland: additional data for Avalon-

758 Gondwana separation by the earliest Palaeozoic. Palaeogeography, Palaeoclimatology,

759 Palaeoecology, 285: 174-185.

760 Leblanc, M. 1976. Proterozoic oceanic crust at Bou Azzer. Nature, 261: 34-35.

761 Leblanc, M., Lancelot, J.R. 1980. Interprétation géodynamique du domaine pan-africain

762 (Précambrien terminal) de l'Anti-Atlas (Maroc) à partir de données géologiques et

763 géochronologiques. Canadian Journal of Earth Sciences, 17: 142-155.

764 Le Heron, D., Ghienne, J.-F., El Houicha, M., Khoukhi, Y., Rubino, J.-L. 2007. Maximum

765 extent of ice sheets in Morocco during the Late Ordovician glaciation. Palaeogeography,

766 Palaeoclimatology, Palaeoecology, $245: 200-226$.

767 Letsch, D. 2017. A pioneer of Precambrian geology: Boris Choubert's fit of the continents

768 across the Atlantic (1935) and his insights into the Proterozoic tectonic structure of the

769 West African Craton and adjacent areas. Precambrian Research, 294: 230-243.

770 Linnemann, U., Pereira, F., Jeffries, T.E., Drost, K., Gerdes, A. 2008. The Cadomian orogeny

771 and the opening of the Rheic ocean: the diachrony of geotectonic processes constrained by

772 LA-ICP-MS U-Pb zircon dating (Ossa-Morena and Saxo-Thuringian zones, Iberian and

773 Bohemian massifs. Tectonophysics, 461: 21-43.

774 Ludwig, K.R. 2003. User's manual for Isoplot 3.0, a geochronological toolkit for Microsoft

775 excel. Berkeley Geochronology Center Special Publication, 4: 1-70.

776 Marzoli, A., Davies, J.H.F.L., Youbi, N., Merle, R., Dal Corso, J., Dunkley, D.J., Fioretti,

777 A.M., Bellieni, G., Medina, F., Wotzlaw, J.-F., McHone, G., Font, E., Bensalah, M.K. 
778

779

780

781

782

783

784

785

786

787

788

789

790

791

792

793

794

795

796

797

798

799

2017. Proterozoic to Mesozoic evolution of North-West Africa and Peri-Gondwana

microplates: detrital zircon ages from Morocco and Canada. Lithos, 278-281: 229-239.

Masini, E., Manatschal, G., Mohn, G. 2013. The Alpine Tethys rifted margins: reconciling old and new ideas to understand the stratigraphic architecture of magma-poor rifted margins, Sedimentology, 60: 174-196.

Mattauer, M., Proust, F., Tapponier, P. 1972. Major strike-slip fault of Hercynian age in Morocco. Nature, 237: 160-162.

Mergl, M., Geyer, G., El Attari, A. 1998. The billingsellid genus Saccogonum (Brachiopoda) from the Moroccan Cambrian and its significance for the regional geology and stratigraphy. Neues Jahrbuch für Geologie und Paläontologie Abhandlungen, 209: 273293.

Meinhold, G., Morton, A.C., Avigad, D. 2013. New insights into peri-Gondwana paleogeography and the Gondwana super-fan system from detrital zircon $\mathrm{U}-\mathrm{Pb}$ ages. Gondwana Research, 23: 661-665.

Michard, A.. 1976. Eléments de Géologie Marocaine. Notes et Mémoires du Service Géologique, 252: 1-408.

Michard, A., Hoepffner, C., Soulaimani, A., Baidder, L. 2008. The Variscan Belt. In Continental Evolution: the Geology of Morocco. Edited by A. Michard, O. Saddiqi, A. Chalouan, D. Frizon de Lamotte. Springer, Berlin/Heidelberg, pp. 65-132.

Michard, A., Soulaimani, A., Hoepffner C., Ouanaimi, H., Baidder, L., Rjimati, E.C., Saddiqi, O. 2010. The south-western branch of the Variscan Belt: evidence from Morocco. Tectonophysics, 492: 1-24. 
800 Morin, P. 1960. Les marbres d'origine métamorphique du Maroc central (géologie et

801 problèmes d'exploitation). Mines et géologie, 11: 31-39.

802 Morin, P. 1962a. Première preuve paléontologique de l'existence du Cambrien dans le Maroc 803 central. Comptes rendus de l'académie des sciences Paris, 254: 2198-2199.

804 Morin, P. 1962b. Les séries volcano-sédimentaires cambriennes du Maroc central. Comptes

805 rendus de l'académie des sciences Paris, 254: 2396-2398.

806 Morin, P. 1962c. Preuve de l'existence de granite précambriens et probabilité de la presence

807 de rhyolites du Précambrien III dans le Maroc central. Comptes rendus de l'académie des

$808 \quad$ sciences Paris, 254: 3227-3229.

809 Morin, P. 1962d. Une vue d'ensemble nouvelle des formations anteviséennes du pays des

810 Zaian (anticlinorium de Kasba-Tadla-Azrou, Maroc central). Comptes rendus de

811 l'académie des sciences Paris, 254: 3385-3387.

812 Murphy, J.B., Nance, R.D. 1989. Model for the evolution of the Avalonian-Cadomian belt.

$813 \quad$ Geology, 17: 735-738.

814 Murphy, J.B., Fernández-Suárez, Keppie, J.D., and Jeffries, T.E. 2004. Contiguous rather than

815 discrete Paleozoic histories for the Avalon and Meguma terranes based on detrital zircon

816 data. Geology, 32: 585-588.

817 Murphy, J.B., Pisarevsky, S., and Nance, R.D. 2013. Potential geodynamic relationships

818 between the development of peripheral orogens along the northern margin of Gondwana

819 and the amalgamation of West Gondwana. Mineralogy and Petrology, 107: 635-650.

820 Nance, R.D., Murphy, J.B. 1994. Contrasting basement isotopic signatures and the

821 palinspastic restoration of peripheral orogens: example from the Neoproterozoic

822 Avalonian-Cadomian belt. Geology, 22: 617-620. 
823 Nance, R.D., Gutiérrez-Alonso, G., Keppie, J.D., Linnemann, U., Murphy, B., Quesada, C., 824 Strachan, R.A., and Woodcock, H. 2012. A brief history of the Rheic Ocean. Geoscience $825 \quad$ Frontiers, 3(2): 125-135.

826

Ouabid, M., Ouali, H., Garrido, C.J., Acosta-Vigil, A., Roman-Alpiste, M.J., Dautria, J.-M., Marchesi, C., Hidas, K. 2017. Neoproterozoic granitoids in the basement of the Moroccan Central Meseta: correlation with the Anti-Atlas at the NW paleo-margin of Gondwana. Precambrian Research, 299: 34-57.

Ouanaimi, H., Soulaimani, A., Hoepffner, C., Michard, A., Baidder, L. 2016. The AtlasMeseta Red Beds basin (Morocco) and the Lower Ordovician rifting of NW-Gondwana. Bulletin de la Société géologique de France, 187/3: 155-168.

Oukassou, M., Lagnaoui, A., Raji, M., Michard, A., Saddiqi, O. 2017. Middle to late Cambrian shallow marine trace fossils from the Imfout Syncline (Western Meseta, Morocco) : palaeoecological and palaeoenvironmental significance in NW-Gondwana. Journal of African Earth Sciences, 129: 492-503.

Pereira, M.F., El Houicha, M., Chichorro, M., Armstrong, R., Jouhari, A., and El Attari, A. 2015. Evidence of a Paleoproterozoic basement in the Moroccan Variscan belt (Rehamna Massif, Western Meseta). Precambrian Research, 268: 61-73.

Pérez-Caceres, I., Martinez Poyatos, D., Simancas, J.F., Azor, A. 2017. Testing the Avalonian affinity of the South Portuguese Zone and the Neoproterozoic evolution of SW Iberia through detrital zircon populations. Gondwana Research, 42: 177-192.

Piqué, A. 1989. Variscan terranes in Morocco. Geological Society of America Special Paper, 230: $115-129$.

Piqué, A. 2001. Geology of Northwest Africa. Borntraeger, Berlin. 
846 Pouclet, A., Arab, A., Fekkak, A., and Benharref, M. 2007. Geodynamic evolution of the

847 northwestern Paleo-Gondwanan margin in the Moroccan Atlas at the Precambrian-

848 Cambrian boundary. Geological Society of America, Special Paper, 423: 27-60.

849 Raumer, J. von, Stampfli, G.M., Bussy, F. 2003. Gondwana-derived microcontinents - the

850 constituents of the Variscan and Alpine collisional orogens. Tectonophysics, 365: 7-22.

851 Raumer, J. von, Bussy, F., Schaltegger, U., Schulz, B., Stampfli, G.M. 2013. Pre-Mesozoic

852 Alpine basements - their place in the European Paleozoic framework. Geological Society

853 of America Bulletin, 125: 89-108.

854 Ruellan, E. 1985. Géologie des marges continentales passive: évolution de la marge atlantique

855 du Maroc (Mazagan); étude par submersible, seabeam, et sismique réflexion. Thèse de

856 doctorat de l'Université de Bretagne occidentale.

857 Schenk, P.E. 1971. Southeastern Atlantic Canada, Northwestern Africa, and Continental drift.

858 Canadian Journal of Earth Sciences, 8: 1218-1251.

859 Schenk, P.E. 1997. Sequence stratigraphy and provenance on Gondwana's margin: The

860 Meguma Zone (Cambrian to Devonian) of Nova Scotia, Canada. Geological Society of

$861 \quad$ America Bulletin, 109: 395-409.

862 Soulaimani, A., Jaffal, M., Maacha, L., Kchikach, A., Najine, A., Saidi, A. 2006.

863 Modélisation magnétique de la suture ophiolitique de Bou Azzer-El Graara (Anti-Atlas

864 central, Maroc). Implications sur la reconstitution géodynamique panafricaine. Comptes

865 Rendus Geoscience, 338: 153-160.

866 Stampfli, G.M., Hochard, C., Vérard, C., Wilhem, C., and von Raumer, J. 2013. The

867 formation of Pangea. Tectonophysics, 593: 1-19. 
868 Tahiri, A., Montero, P., El Hadi, H., Martinez Poyatos, D. Azor, A., Bea, F., Simancas, J.F., 869 Gonzalez Lodeiro, F. 2010. Geochronological data on the Rabat-Tiflet granitoids: their 870 bearing on the tectonics of the Moroccan Variscides. Journal of African Earth Sciences, $871 \quad$ 57: $1-13$.

872 Talavera, C., Montero, P. Bea, F., Gonzalez Lodeiro, F., Whitehouse, M. 2013. U-Pb zircón 873 geochronology of the Cambro-Ordovician metagranites and metavolcanic rocks of central 874 and NW Iberia. International Journal of Earth Sciences, 102: 1-23.

875 Thomas, R.J., Chevallier, L.P., Gresse, P.G., Harmer, R.E., Eglington, B.M., Armstrong, 876 R.A., de Beer, C.H., Martini, J.E.J., de Kock, G.S., Macey, P.H., Ingram, B.A. 2002.

877 Precambrian evolution of the Sirwa window, Anti-Atlas orogen, Morocco. Precambrian $878 \quad$ Research, 118: 1-57.

879 Triantafyllou, A., Berger, J., Baele, J.-M., Diot, H., Ennih, N., Plissart, G., Monnier, C., 880 Watlet, A., Bruguier, O., Spagna, P., Vandycke, S. 2016. The Tachakoucht-Iriri-Tourtit arc 881 complex (Moroccan Anti-Atlas): Neoproterozoic records of polyphased subduction882 accretion dynamics during the Pan-African orogeny. Journal of Geodynamics, 96: 81-103.

883 Waldron, J.W.F., White, C.E., Barr, S.M., Simonetti, A., Heaman, L.M. 2009. Provenance of 884 the Meguma terrane, Nova Scotia: rifted margin of early Paleozoic Gondwana. Canadian 885 Journal of Earth Sciences, 46: 1-8.

886 Walsh, G.J., Benziane, F., Aleinikoff, J.N., Harrison, R.W., Yazidi, A., Burton, W.C., Quick, 887 J.E., Saadane, A. 2012. Neoproterozoic tectonic evolution of the Jebel Saghro and Bou 888 Azzer- El Graara inliers, eastern and central Anti-Atlas, Morocco. Precambrian Research, 889 216-219: $23-62$.

890 Wilson, J.T. 1966. Did the Atlantic close and then re-open? Nature, 211: 676-681. 


\section{Figure captions:}

893 Figure 1. a: A possible distribution of peri-Gondwanan terranes during the latest Precambrian 894 with the position of the Moroccan Meseta indicated (redrawn and modified after Nance et 895 al. 2002). RO: trace of the future opening of the Rheic Ocean. b: Peri-Gondwanan terranes 896 and the Meseta Domain (black) on a late Paleozoic (Bullard-fit) continental reconstruction 897 (redrawn and modified after Nance and Murphy 1994). AC: Amazonian Craton, SFC: Sao 898 Francisco Craton, WAC: West African Craton, Ch: Chortis Block, Ox: Oaxaquia, Y: $899 \quad$ Yucatan, F: Florida.

Figure 2. Geological overview map of the Moroccan Meseta Domain and the Anti-Atlas Belt.

901 Redrawn and simplified/modified after Michard et al. (2010) and Pereira et al. (2015). The 902 Mid-Cambrian Meseta graben zones are schematically drawn after Bernardin et al. (1988). 903 Post-Paleozoic areas are left blank. Localities studied for the present paper are indicated by 904 asterisks.

905

906

907

908

909

910

911

912

913

914

Figure 3. Field pictures (for locations see Fig. 2). 3a: deformed and recrystallized carbonates (marble) from Bou Ibenrhar; 3b: carbonate grainstone with symmetric ripple marks (Bou Ibenrhar, 15DL4; for thin section pictures see Figs. 6a,b); 3c: pillow metabasalts (Bou Ibenrhar); 3d: breccia (Bou Ibenrhar: 15DL4); 3e: rhyolite from Jbel Hadid (15DL8); 3f: ooid grainstone at El Jadida (view on bedding plane; for thin section pictures see Figs. $6 c, d)$

Figure 4. Schematic geological sections across the Jbel Hadid and the Bou Ibenrhar plane in the southeast corner of the Central Massif of the Moroccan Meseta (for location see Fig. 2). Sample locations are indicated. Drawn after own observations with some additional information from Morin (1962b). Informal formations 1 to 5 have been defined and color- 
915 coded on both cross sections. These correlations are based purely on lithologic 916 comparisons.

917 Figure 5. Selected thin section photographs from volcanic and clastic rocks from the Meseta 918 Domain (all pictures taken under crossed nicols). 5a: Almost undeformed rhyolite from 919 Bou Ibenrhar (sample 15DL1). 5b: coarse grained greywacke from unit 4 (the 920 "Paradoxides Shales"), Bou Ibenrhar (sample 15DL6). 5c: Deformed (?) metarhyolite 921 (crenulated mica schist with isolated feldspar and quartz grains) from unit 1 of the Jbel 922 Hadid section. 5d: volcanoclastic breccia from unit 2 of the Jbel Hadid section (sample 923 15DL10): rhyolite fragments and isolated quartz and feldspar grains in a fine grained 924 quartz/feldspar/chlorite/sericite matrix. 5e: Matrix of deformed metaconglomerate from the 925 Sidi Ali section: coarser- and finer grained quartz rich domains delineate former pebbles 926 (the lower finer grained one containing abundant tourmaline). Note abundant metamorphic 927 mica flakes (sample 15DL11). 5f: Fine grained quartz sandstone from the Im Fout locality 928 (Upper Cambrian El Hank Sandstone).

929

930

931

933

934

936

937

938

Figure 6: a/b: Two thin section photographs (ordinary light) from a partially recrystallized but otherwise undeformed carbonate grainstone from the Central Massif (sample 15DL 4, Bou Ibenrhar, for locality see Fig. 2). c/d: thin section photographs of a partially recrystallized ooid-grainstone from El Jadida. See text for further explanations.

Figure 7: Stratigraphic correlation scheme of the areas studied in this paper. Sample localities, chronostratigraphic constraints, and the informal subdivision proposed in the text (Groups I to IV) are furthermore indicated.

Figure 8: U/Pb LA-ICP-MS ages from a rhyolite from Jbel Hadid (15DL9, see Fig. 4 for location). a: weighted average plot displaying individual ages from different zircon grains. See text for further explanation. b: Concordia diagram of the same ages displayed in a. 
939 Figure 9: Relative probability (probability density) plots displaying the age distribution from

940 detrital zircons from two sandstone samples from the Meseta Domain. See Fig. 2 for

941 sample localities. a: sample 15DL6 ("Schistes à Paradoxides") from the Central Massif; b:

942 sample 15DL12 (El Hank Sandstone) from the Coastal Block.

943 Figure 10: Schematic paleogeographic sketch for the Ediacaran, displaying a possible

944 scenario at Gondwana's periphery (Fig. 10a) with the spatial relationships among the Anti-

945 Atlas Domain, the Meseta Domain and Cadomia. Note that the Bou Azzer suture is only

946 very schematically drawn and no suggestions as to its concrete geometry are implied (see

947 Soulaimani et al. 2006 for such a discussion). Synoptic stratigraphic charts for the latter

948 two domains are shown in figures 10b (after Murphy et al. 2013) and 10c (summarizing

949 data from the present study). 

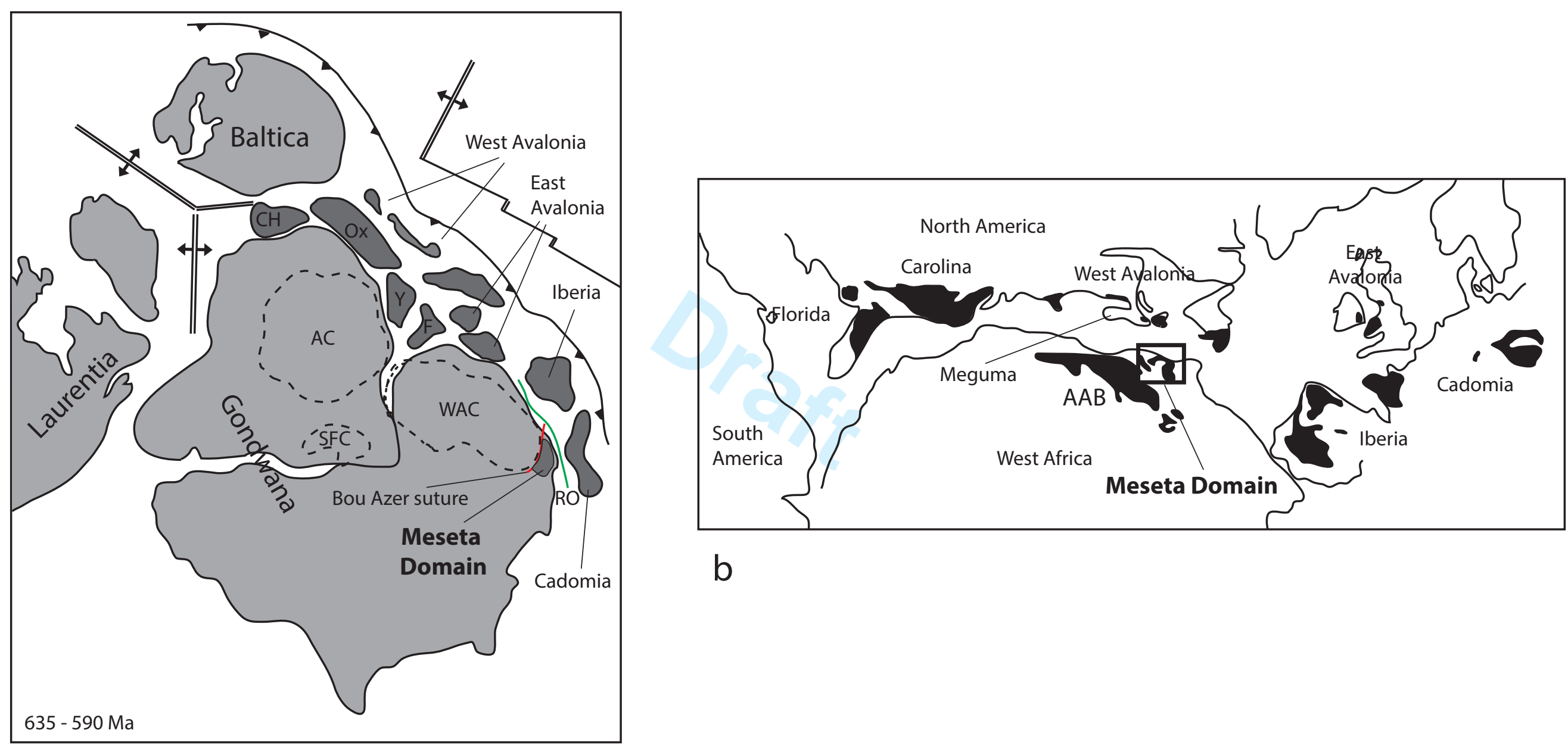

b

a 


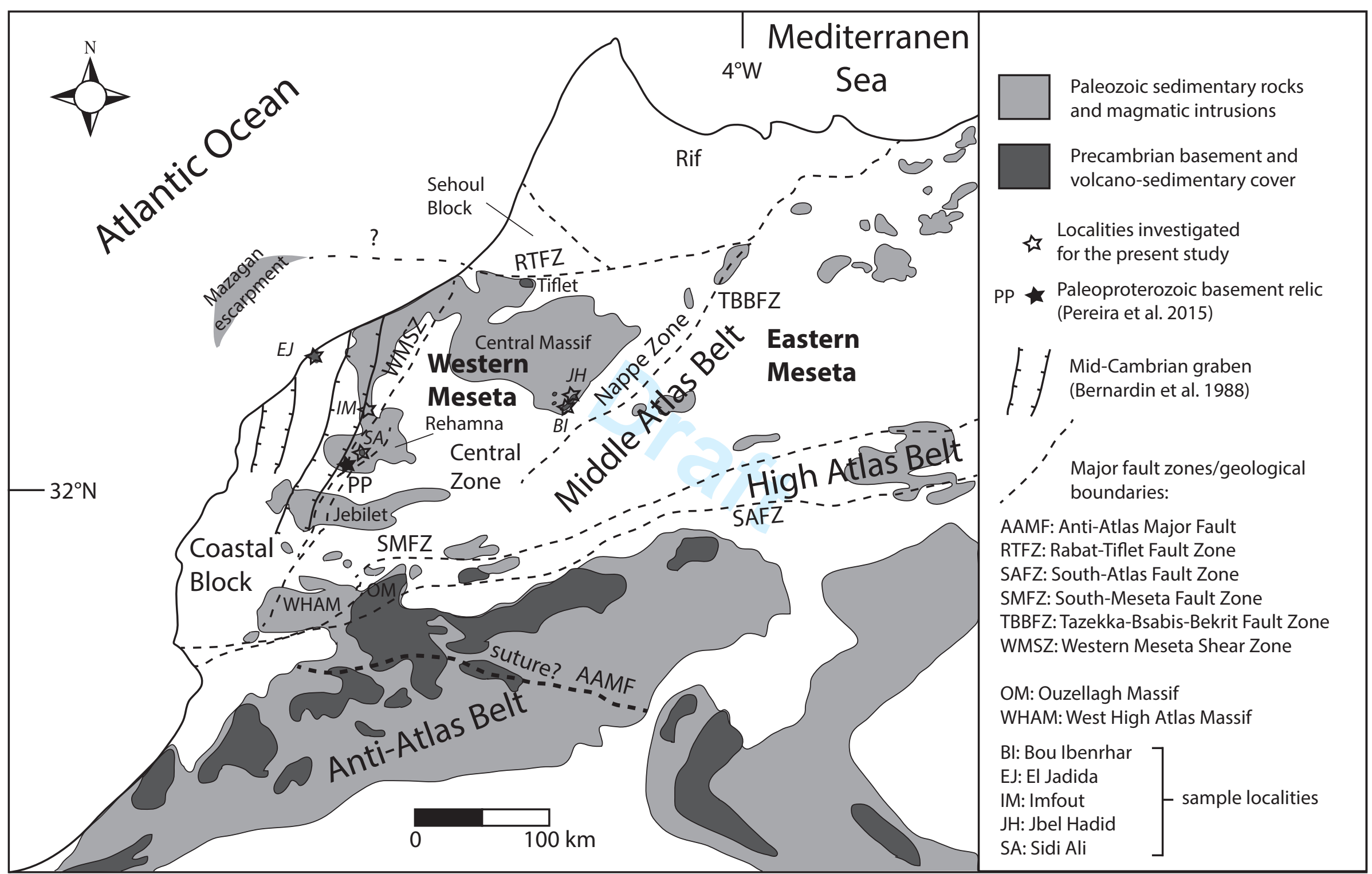




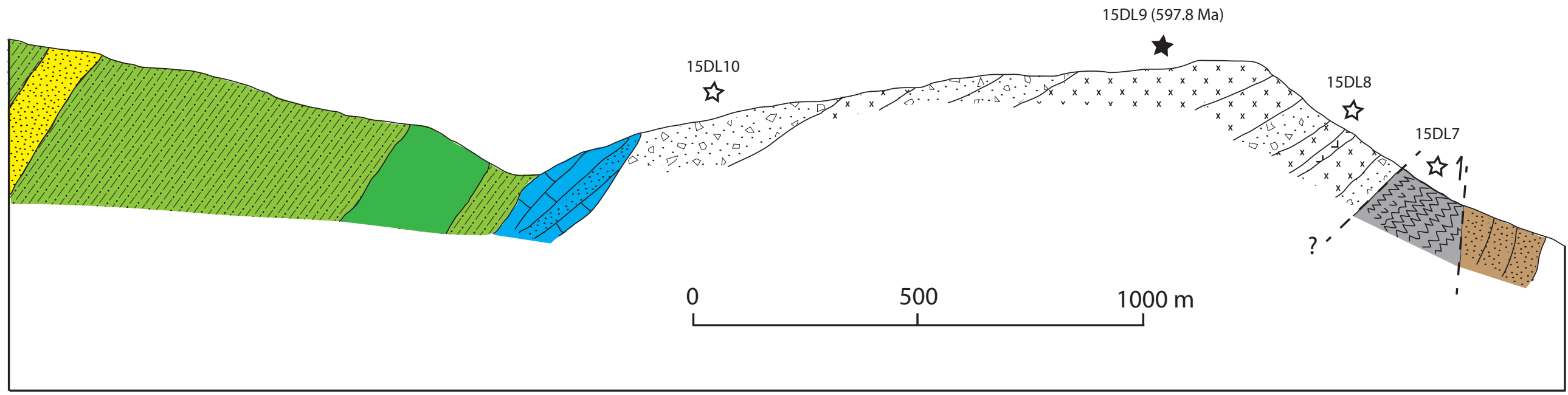

\section{A) Jbel Hadid section}

NNW
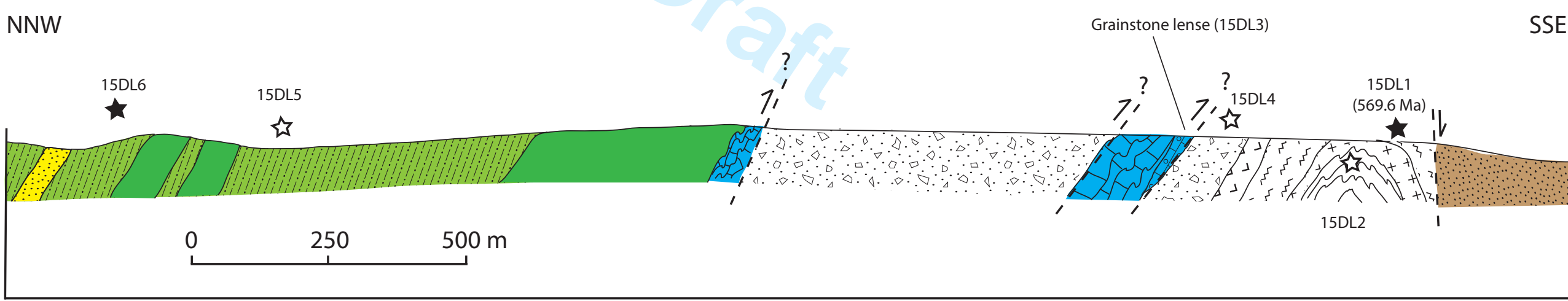

\section{B) Bou lbenrhar section}

3. Carbonates with subordinate sandy intercalations (partly recrystallized and heavily deformed)

2: Breccias, sandstones, phyllites, rhyolites, and intermediate to mafic volcanic flows

1: Schists with crenulations and some volcanic intercalation
5: “Cambri-Ordovician” (sandstones, phyllites)

4: Shales with greywacke intercalation and basic flows ("Paradoxides Shales")

http $5 /$ m 6 .manuscriptcentral.com/cjes-pubs Quartz sandstone
Sample for geochronology (yielding zircons) with suggested age of emplacement (see text for further discussion)

Sample for geochronology (yielding no zircons) 

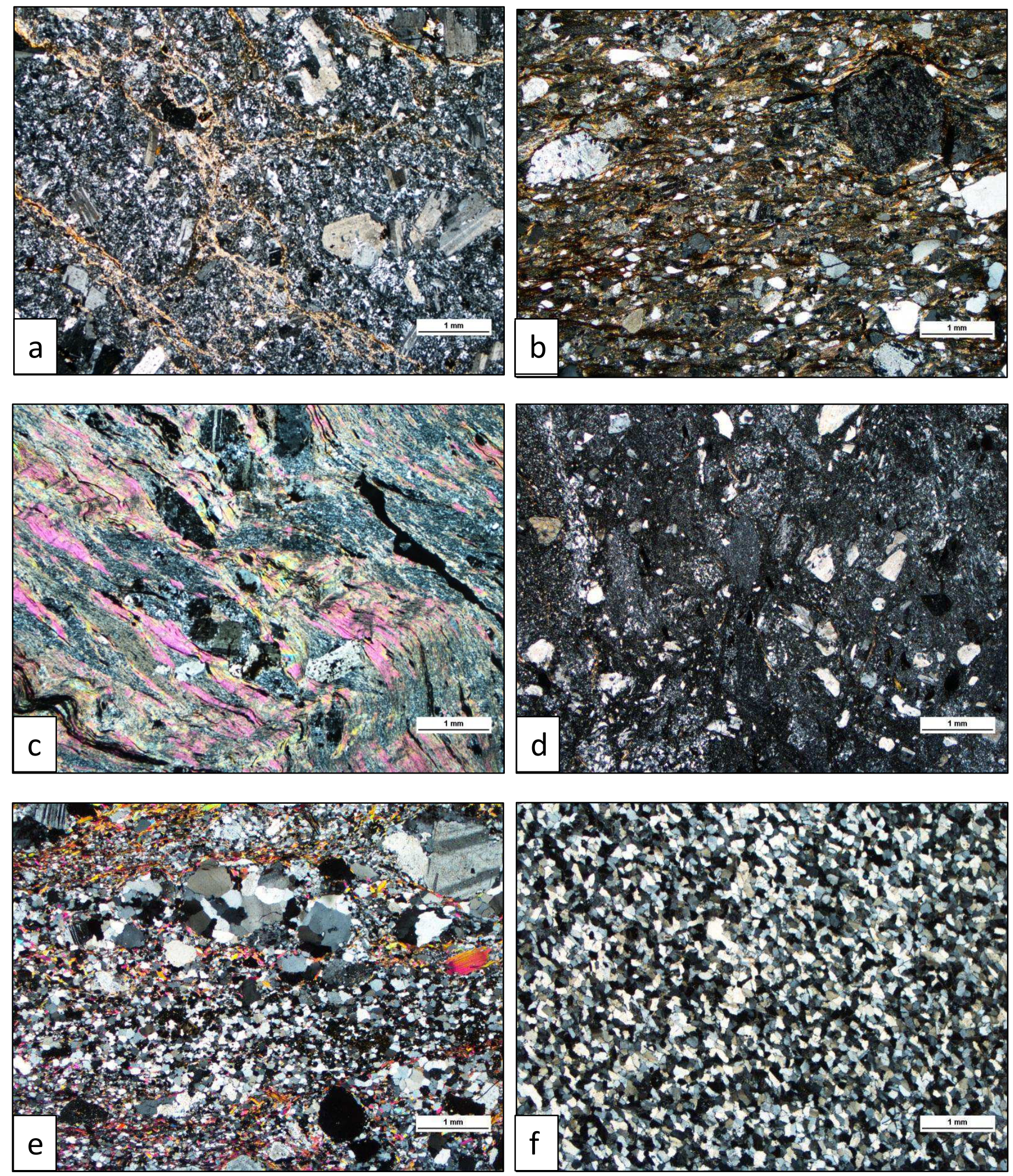


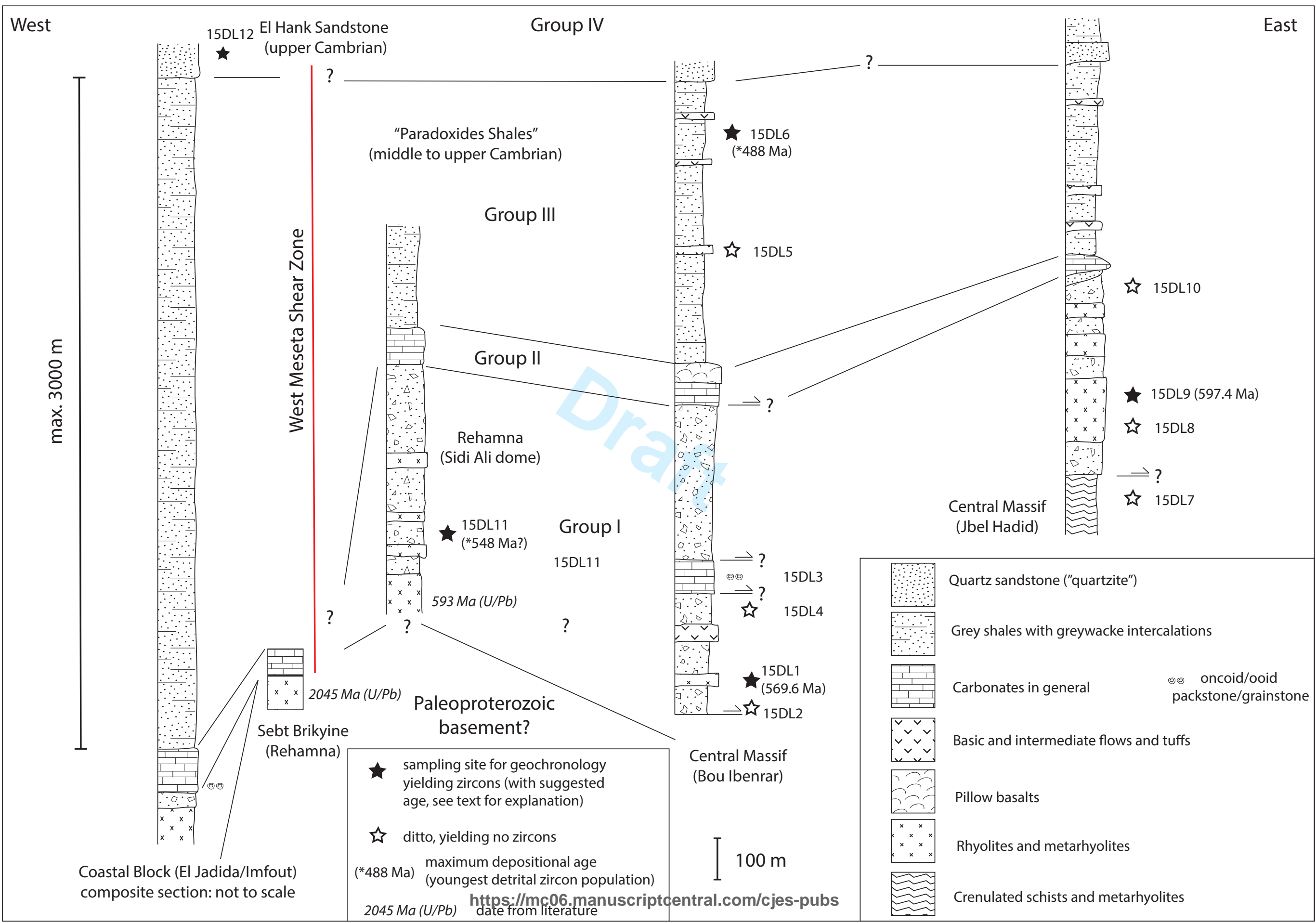




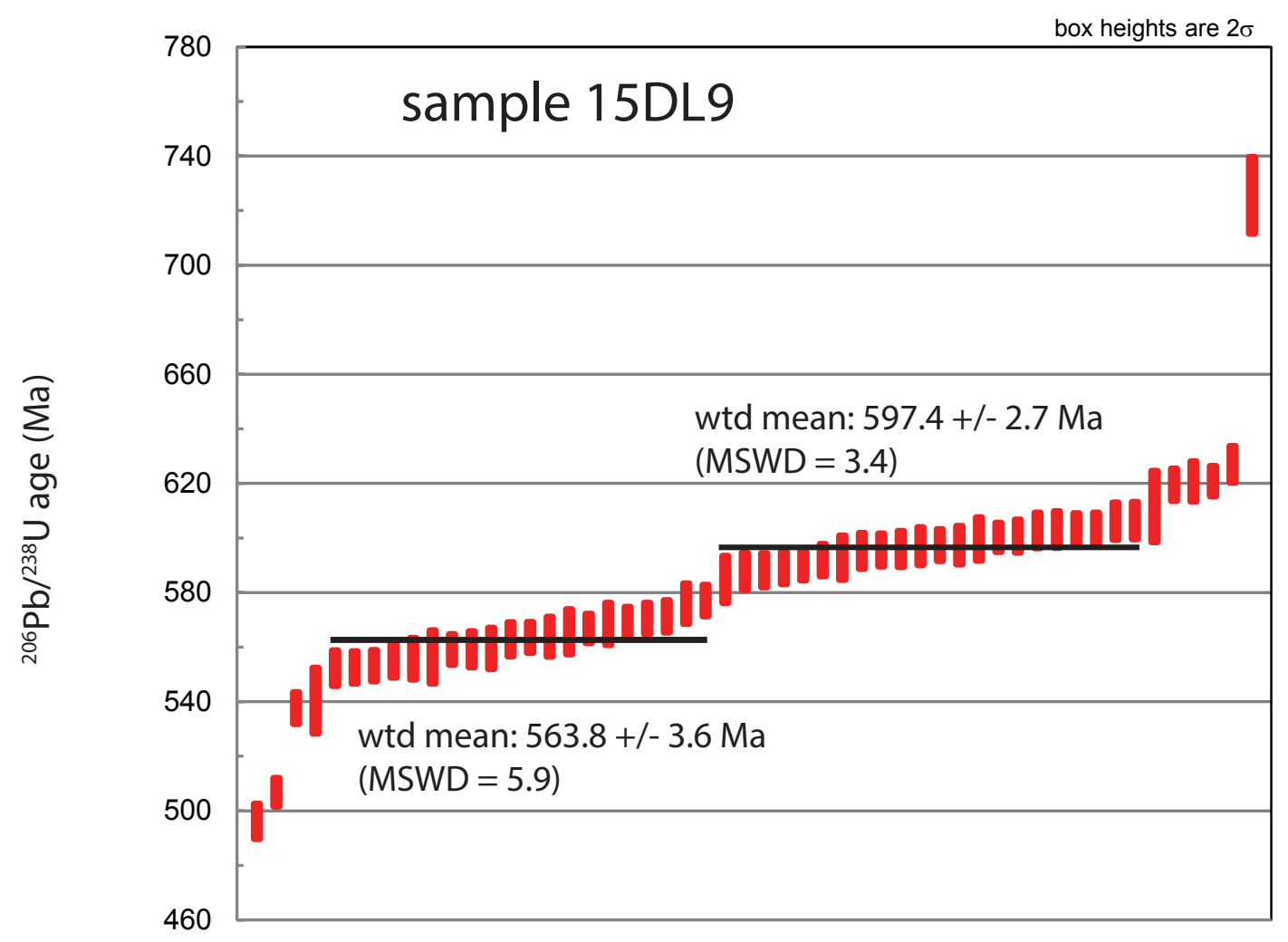

a

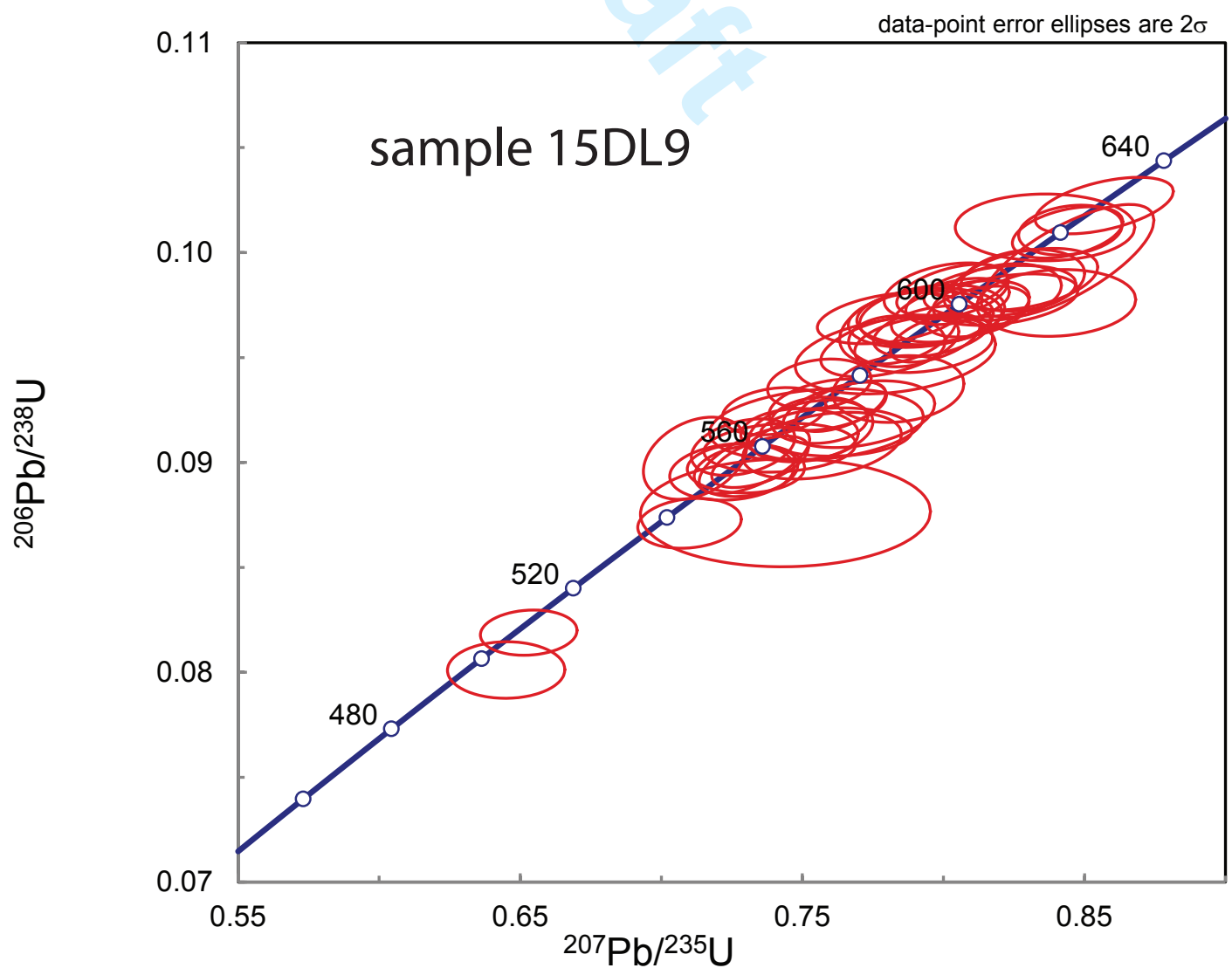

b 
a

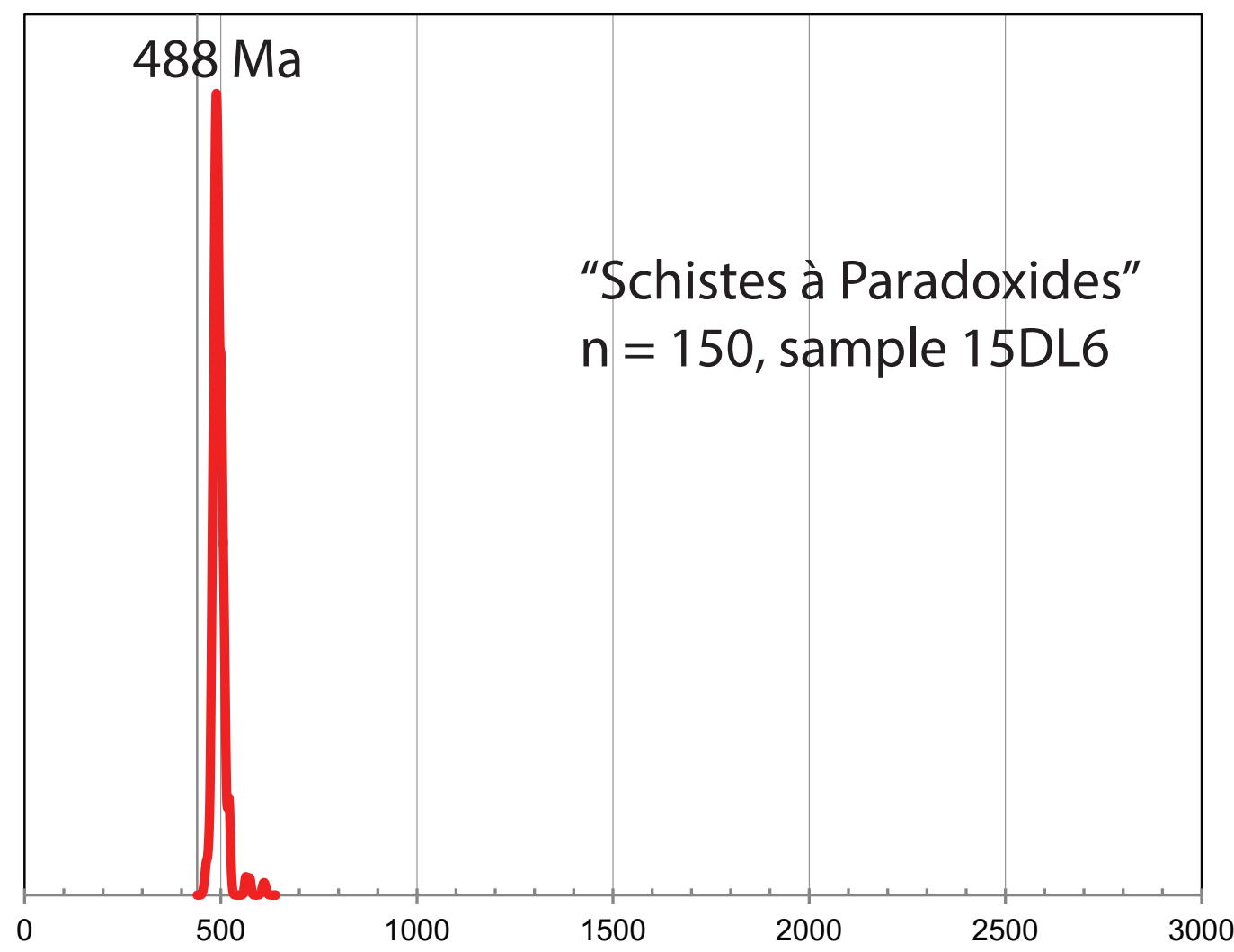

${ }^{206} \mathrm{~Pb} /{ }^{238} \mathrm{U}$ age (Ma)

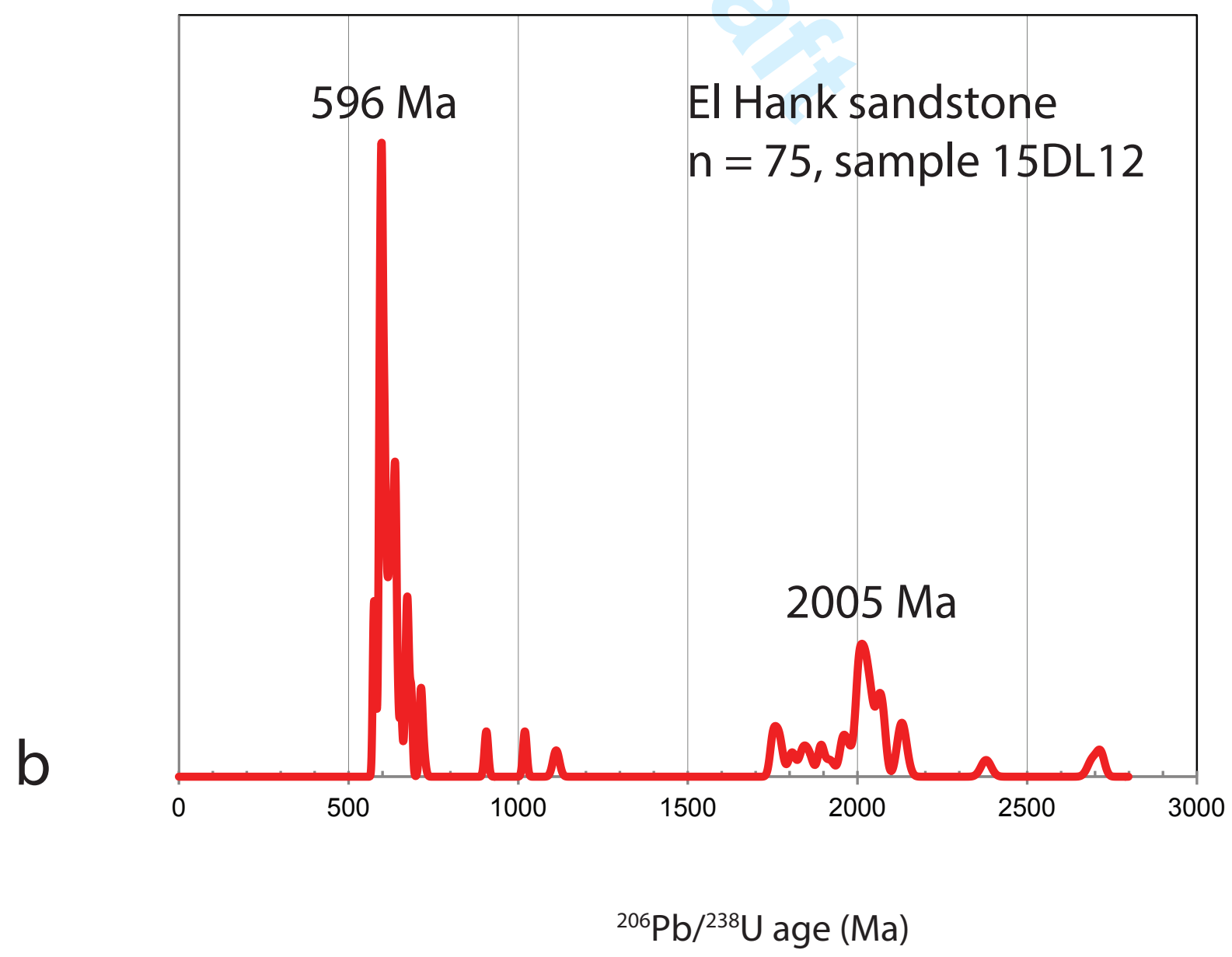




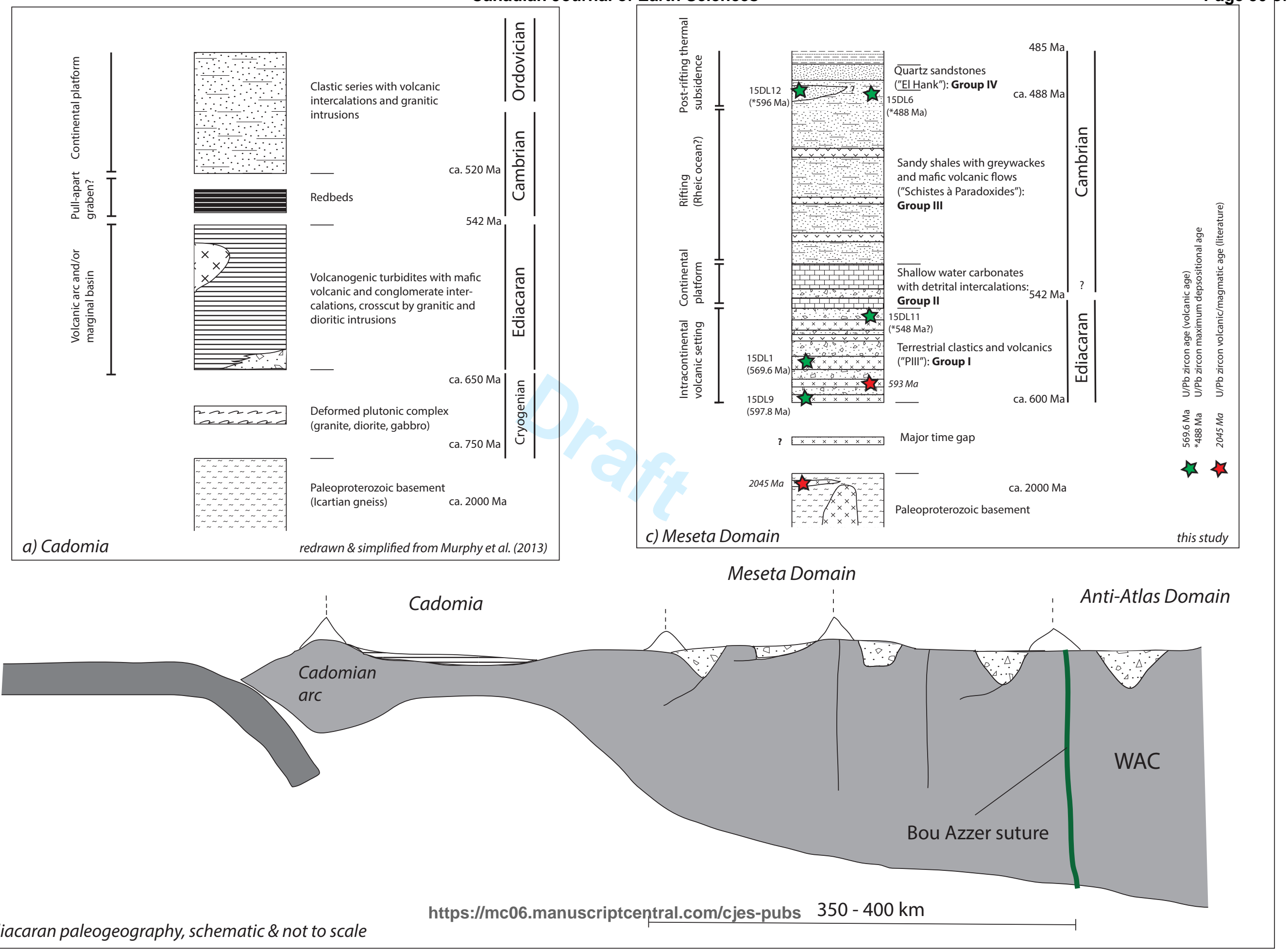




\begin{tabular}{|c|c|c|c|c|c|}
\hline \multicolumn{2}{|c|}{ Sample localities } & & & & \\
\hline $\begin{array}{l}\text { Sampl } \\
\text { e \# }\end{array}$ & $\begin{array}{l}\text { Coordinat } \\
\text { es }\end{array}$ & & Lithology & $\begin{array}{l}\text { enough zircons } \\
\text { for analysis }\end{array}$ & $\begin{array}{l}\text { sample only for } \\
\text { petrography }\end{array}$ \\
\hline & $\begin{array}{l}\mathrm{N}, \mathrm{W} \\
\text { respect. }\end{array}$ & & & (yes/no) & \\
\hline 15DL1 & $32^{\circ} 45^{\prime} 43.5$ & $5^{\circ} 58^{\prime} 32.7^{\prime \prime}$ & greenish-reddish rhyolite & yes & \\
\hline 15DL2 & $\begin{array}{l}32^{\circ} 45^{\prime} 43.5 \\
" 1\end{array}$ & $5^{\circ} 58^{\prime} 32.7^{\prime \prime}$ & fine grained volcanoclastics & no & \\
\hline 15DL3 & $32^{\circ} 46^{\prime} 0.8^{\prime \prime}$ & $5^{\circ} 58^{\prime} 31.8^{\prime \prime}$ & oolitic carbonate & & yes \\
\hline 15DL4 & $32^{\circ} 46^{\prime} 1.5^{\prime \prime}$ & $5^{\circ} 58^{\prime} 39^{\prime \prime}$ & breccia & yes & \\
\hline 15DL5 & $32^{\circ} 46^{\prime} 49.9$ & $5^{\circ} 59^{\prime} 6.3^{\prime \prime}$ & laminated pelite ("cinerite") & no & \\
\hline 15DL6 & $32^{\circ} 47^{\prime} 0.7^{\prime \prime}$ & $5^{\circ} 59^{\prime} 13.2^{\prime \prime}$ & $\begin{array}{l}\text { immature sandstone } \\
\text { (greywacke) }\end{array}$ & yes & \\
\hline 15DL7 & $\begin{array}{l}32^{\circ} 48^{\prime} 39.8 \\
" 1\end{array}$ & $5^{\circ} 50^{\prime} 30.7^{\prime \prime}$ & $\begin{array}{l}\text { green phyllite with } \\
\text { crenulation (metarhyolite) }\end{array}$ & no & \\
\hline 15DL8 & $32^{\circ} 48^{\prime} 24.2$ & $5^{\circ} 50^{\prime} 23.9^{\prime \prime}$ & rhyolite & no & \\
\hline 15DL9 & $\begin{array}{l}32^{\circ} 48^{\prime} 38.3 \\
" 1\end{array}$ & $5^{\circ} 50^{\prime} 8.8^{\prime \prime}$ & rhyolite & yes & \\
\hline $\begin{array}{l}\text { 15DL1 } \\
0\end{array}$ & $\begin{array}{l}32^{\circ} 48^{\prime} 47.7 \\
" 1\end{array}$ & $\begin{array}{l}5^{\circ} 49^{\prime} 45.1 \\
0^{\prime \prime}\end{array}$ & green breccia & no & \\
\hline $\begin{array}{l}\text { 15DL1 } \\
1\end{array}$ & $32^{\circ} 22^{\prime} 3.6^{\prime \prime}$ & $\begin{array}{l}7^{\circ} 58^{\prime} 13.4 \\
2^{\prime \prime}\end{array}$ & $\begin{array}{l}\text { matrix from } \\
\text { metaconglomerate }\end{array}$ & yes & \\
\hline $\begin{array}{l}15 \mathrm{DL} 1 \\
2\end{array}$ & $\begin{array}{l}32^{\circ} 44^{\prime} 43.2 \\
\text { " }\end{array}$ & $7^{\circ} 56^{\prime} 51.9^{\prime \prime}$ & quartz sandstone & yes & \\
\hline $\mathrm{J} 3 \mathrm{C}$ & $33^{\circ} 15^{\prime} 47.9$ & $8^{\circ} 30^{\prime} 48.4^{\prime \prime}$ & oolithic carbonate & & yes \\
\hline
\end{tabular}


15DL1, rhyolite, Group I (Ediacaran)

\# Isotopic ratios (and $2 \sigma$ errors)

$\begin{array}{rrrrrrr} & 207 \mathrm{~Pb} / & & 206 \mathrm{~Pb} / & & 207 \mathrm{~Pb} / & \\ & 235 \mathrm{U} & \% \pm & 238 \mathrm{U} & \% \pm & 206 \mathrm{~Pb} & \% \pm \\ & & & & & & \\ 1 & 0.766 & 0.017 & 0.09229 & 0.001 & 0.0595 & 0.0013 \\ 2 & 0.749 & 0.018 & 0.093 & 0.0013 & 0.0582 & 0.0012 \\ 3 & 0.736 & 0.017 & 0.09197 & 0.0011 & 0.0585 & 0.0013\end{array}$

Isotopic ages (and $2 \sigma$ erros)

Disc.

$\begin{array}{rrrrrrr}207 \mathrm{~Pb} / & & 206 \mathrm{~Pb} / & & \begin{array}{r}207 \mathrm{~Pb} / \\ 206 / \mathrm{Pb}\end{array} \\ 235 \mathrm{U} & \pm & \pm & \% \\ & & & & & & \\ 577.3 & 9.8 & 569 & 6 & 590 & 46 & 98.56 \\ 566.9 & 11 & 574.3 & 8 & 528 & 47 & 101.31 \\ 560.7 & 10 & 567.1 & 6.6 & 540 & 46 & 101.14\end{array}$

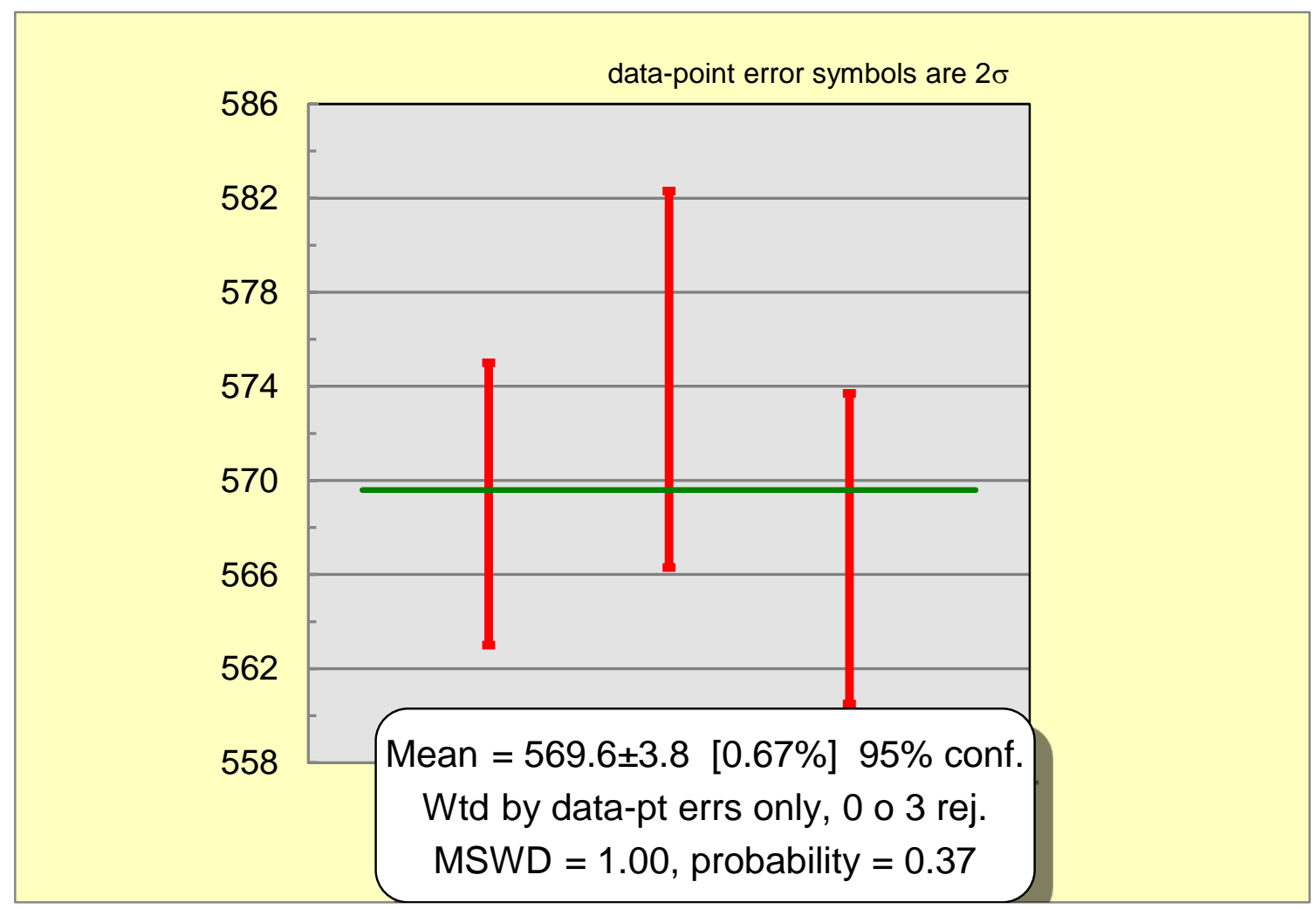

15DL6, greywacke, Group III (upper Cambrian)

\begin{tabular}{|c|c|c|c|c|c|c|}
\hline & 207Pb/ & & $206 \mathrm{~Pb} /$ & & $207 \mathrm{~Pb} /$ & \\
\hline & $235 \mathrm{U}$ & $\% \pm$ & $238 \mathrm{U}$ & $\% \pm$ & $206 \mathrm{~Pb}$ & $\% \pm$ \\
\hline 4 & 0.6101 & 0.012 & 0.0741 & 0.0013 & 0.06001 & 0.0011 \\
\hline 5 & 0.5842 & 0.012 & 0.07467 & 0.00094 & 0.05682 & 0.00087 \\
\hline 6 & 0.5903 & 0.011 & 0.07548 & 0.00085 & 0.05697 & 0.00086 \\
\hline 7 & 0.606 & 0.016 & 0.07596 & 0.00097 & 0.0575 & 0.0014 \\
\hline 8 & 0.605 & 0.015 & 0.07645 & 0.0011 & 0.0574 & 0.0012 \\
\hline 9 & 0.596 & 0.015 & 0.07647 & 0.001 & 0.0563 & 0.0013 \\
\hline 10 & 0.614 & 0.015 & 0.0767 & 0.0012 & 0.0585 & 0.0011 \\
\hline 11 & 0.6135 & 0.012 & 0.07674 & 0.0011 & 0.05774 & 0.00089 \\
\hline 12 & 0.601 & 0.014 & 0.07678 & 0.00098 & 0.05652 & 0.001 \\
\hline 13 & 0.609 & 0.015 & 0.07691 & 0.00095 & 0.0577 & 0.0012 \\
\hline 14 & 0.611 & 0.013 & 0.07693 & 0.00096 & 0.05745 & 0.001 \\
\hline 15 & 0.61 & 0.015 & 0.07681 & 0.00094 & 0.0582 & 0.0014 \\
\hline 16 & 0.609 & 0.018 & 0.07695 & 0.0009 & 0.0572 & 0.0011 \\
\hline 17 & 0.598 & 0.015 & 0.07708 & 0.00088 & 0.0564 & 0.0012 \\
\hline
\end{tabular}

\begin{tabular}{crrrrrr} 
Isotopic ages (and 20 erros) & & & & Disc. \\
$207 \mathrm{~Pb} /$ & & $206 \mathrm{~Pb} /$ & \multicolumn{2}{c}{$207 \mathrm{~Pb} /$} & & \\
$235 \mathrm{U}$ & \pm & $238 \mathrm{U}$ & $\pm 206 / \mathrm{Pb}$ & \pm & $\%$ \\
& & & & & & \\
483.4 & 7.6 & 460.7 & 8 & 599 & 38 & 95.30 \\
466.9 & 7.6 & 464.2 & 5.6 & 481 & 34 & 99.42 \\
471.6 & 7 & 469.1 & 5.1 & 496 & 33 & 99.47 \\
480.6 & 10 & 471.9 & 5.8 & 539 & 52 & 98.19 \\
480.5 & 9.7 & 474.9 & 6.7 & 502 & 46 & 98.83 \\
475.4 & 9.6 & 475 & 6 & 461 & 54 & 99.92 \\
487.2 & 9.3 & 476.5 & 7 & 545 & 42 & 97.80 \\
485.6 & 7.7 & 476.6 & 6.5 & 517 & 34 & 98.15 \\
477.3 & 8.7 & 476.8 & 5.9 & 477 & 41 & 99.90 \\
483.6 & 9.3 & 477.6 & 5.7 & 517 & 45 & 98.76 \\
483.6 & 8.4 & 477.7 & 5.8 & 508 & 39 & 98.78 \\
483.1 & 9.4 & 477.8 & 5.8 & 529 & 52 & 98.90 \\
482.5 & 11 & 477.9 & 5.4 & 508 & 44 & 99.05 \\
475.7 & 9.3 & 478.7 & 5.2 & 468 & 47 & 100.63
\end{tabular}




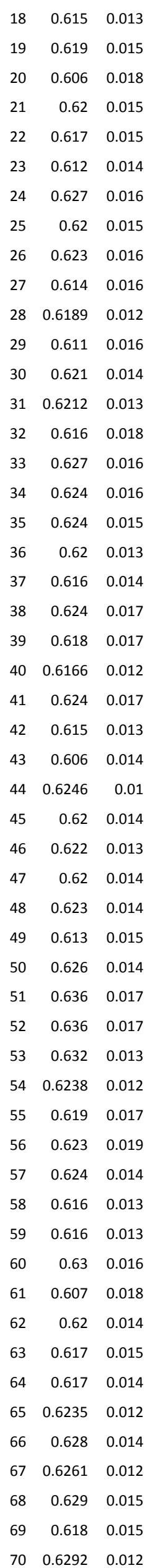

\begin{tabular}{|c|c|c|c|}
\hline 7709 & 0.0011 & .05789 & 0.00 \\
\hline 0.07722 & 0.0011 & 0.0578 & 0.0014 \\
\hline 07739 & 0.0011 & 0.057 & 0.0017 \\
\hline 0.07738 & 0.001 & 0.05773 & 0.00092 \\
\hline 0.07742 & 0.00077 & 0.0571 & 0.0012 \\
\hline .07746 & 0.00086 & 0.057 & 0.0011 \\
\hline 0.07756 & 0.001 & 0.058 & 0.0015 \\
\hline 0.07755 & 0.00089 & 0.0579 & 0.0013 \\
\hline 0.07762 & 0.00092 & 0.0583 & 0.0013 \\
\hline 0.07764 & 0.001 & 0.0578 & 0.0012 \\
\hline 0.07768 & 0.00084 & 0.05791 & 0.00098 \\
\hline 0.07777 & 0.00091 & 0.057 & 0.0012 \\
\hline 0.07779 & 0.00099 & 0.0578 & 0.0012 \\
\hline 0.0778 & 0.00072 & 0.05774 & 0.00095 \\
\hline 0.0778 & 0.0011 & 0.0569 & 0.0013 \\
\hline 0.07798 & 0.00094 & 0.0587 & 0.0013 \\
\hline 0.07803 & 0.00097 & 0.0578 & 0.0013 \\
\hline 0.07813 & 0.00084 & 0.0583 & 0.0014 \\
\hline 0.07813 & 0.0009 & 0.0575 & 0.0011 \\
\hline .07816 & 0.001 & 0.057 & 0.0012 \\
\hline 0.07819 & 0.00093 & 0.058 & 0.0015 \\
\hline .07822 & 0.001 & 0.057 & 0.0013 \\
\hline 0.07823 & 0.00083 & 0.05708 & 0.00087 \\
\hline 0.07826 & 0.00086 & 0.0578 & 0.0013 \\
\hline 0.07827 & 0.00095 & 0.057 & 0.0012 \\
\hline 0.0783 & 0.00081 & 0.05625 & 0.001 \\
\hline 0.07835 & 0.00091 & 0.05791 & 0.00076 \\
\hline 0.07839 & 0.00093 & 0.05758 & 0.00096 \\
\hline 0.07839 & 0.00078 & 0.057 & 0.00097 \\
\hline 0.0784 & 0.0012 & 0.05775 & 0.00098 \\
\hline 0.07841 & 0.0009 & 0.0576 & 0.0012 \\
\hline 0.07842 & 0.00097 & 0.057 & 0.0013 \\
\hline 0.07844 & 0.00099 & 0.05734 & 0.001 \\
\hline 0.0785 & 0.0014 & 0.0588 & 0.0014 \\
\hline 0.0785 & 0.0012 & 0.0586 & 0.0015 \\
\hline .07851 & 0.00097 & 0.058 & 0.0011 \\
\hline 0.07855 & 0.00088 & 0.05784 & 0.00086 \\
\hline 0.0786 & 0.0012 & 0.0569 & 0.0016 \\
\hline 0.07867 & 0.0011 & 0.0575 & 0.0017 \\
\hline 0.07866 & 0.00099 & 0.0584 & 0.0011 \\
\hline 0.07867 & 0.00083 & 0.05684 & 0.00098 \\
\hline 0.07869 & 0.00082 & 0.0568 & 0.0011 \\
\hline 0.07872 & 0.00097 & 0.0576 & 0.0013 \\
\hline 0.0788 & 0.00086 & 0.0561 & 0.0015 \\
\hline 0.0788 & 0.001 & 0.0576 & 0.0011 \\
\hline 0.07886 & 0.00088 & 0.0563 & 0.0012 \\
\hline 0.07889 & 0.00095 & 0.05686 & 0.001 \\
\hline 0.07891 & 0.00085 & 0.0573 & 0.00088 \\
\hline 0.07891 & 0.00089 & 0.0581 & 0.0011 \\
\hline 0.07892 & 0.00085 & 0.05741 & 0.00084 \\
\hline 0.0789 & 0.00095 & 0.0577 & 0.0013 \\
\hline 0.07897 & 0.00093 & 0.057 & 0.0011 \\
\hline & 0.0011 & 0.058 & 0.0009 \\
\hline
\end{tabular}

\begin{tabular}{|c|c|c|c|c|c|c|}
\hline 486.7 & 8 & 478.7 & 6.6 & 523 & 32 & 98.36 \\
\hline 488.9 & 9.2 & 479.5 & 6.5 & 520 & 54 & 98.08 \\
\hline 481 & 11 & 480.5 & 6.6 & 495 & 62 & 99.90 \\
\hline 489.5 & 9.1 & 480.5 & 6 & 523 & 37 & 98.16 \\
\hline 487.3 & 9.7 & 480.7 & 4.6 & 500 & 46 & 98.65 \\
\hline 484.5 & 8.5 & 480.9 & 5.2 & 502 & 41 & 99.26 \\
\hline 493.7 & 10 & 481.5 & 6 & 543 & 54 & 97.53 \\
\hline 489.6 & 9.7 & 481.5 & 5.3 & 543 & 51 & 98.35 \\
\hline 491.4 & 10 & 481.9 & 5.5 & 533 & 50 & 98.07 \\
\hline 486 & 10 & 482 & 6 & 518 & 45 & 99.18 \\
\hline 489 & 7.4 & 482.2 & 5 & 534 & 37 & 98.61 \\
\hline 485.2 & 10 & 482.8 & 5.4 & 489 & 48 & 99.51 \\
\hline 489.9 & 8.9 & 482.9 & 5.9 & 515 & 45 & 98.57 \\
\hline 491.3 & 7.7 & 482.9 & 4.3 & 515 & 36 & 98.29 \\
\hline 487 & 12 & 482.9 & 6.4 & 497 & 51 & 99.16 \\
\hline 493.6 & 10 & 484 & 5.6 & 549 & 46 & 98.06 \\
\hline 492.1 & 9.7 & 484.3 & 5.8 & 523 & 49 & 98.41 \\
\hline 493.2 & 9.9 & 484.9 & 5 & 532 & 52 & 98.32 \\
\hline 491.1 & 8.7 & 485 & 5.4 & 518 & 45 & 98.76 \\
\hline 487 & 8.9 & 485.1 & 6.1 & 483 & 47 & 99.61 \\
\hline 491.4 & 11 & 485.3 & 5.6 & 517 & 57 & 98.76 \\
\hline 487.8 & 11 & 485.5 & 6 & 510 & 53 & 99.53 \\
\hline 487.6 & 7.4 & 485.6 & 5 & 493 & 34 & 99.59 \\
\hline 492.9 & 10 & 485.7 & 5.1 & 524 & 50 & 98.54 \\
\hline 486.3 & 8.4 & 485.8 & 5.7 & 496 & 44 & 99.90 \\
\hline 480.6 & 8.8 & 486 & 4.8 & 462 & 41 & 101.12 \\
\hline 492.6 & 6.4 & 486.3 & 5.5 & 524 & 29 & 98.72 \\
\hline 489.3 & 8.5 & 486.5 & 5.6 & 509 & 37 & 99.43 \\
\hline 490.9 & 8.3 & 486.5 & 4.7 & 497 & 38 & 99.10 \\
\hline 489.2 & 8.7 & 486.5 & 7.3 & 515 & 37 & 99.45 \\
\hline 492.3 & 9.3 & 486.6 & 5.4 & 515 & 47 & 98.84 \\
\hline 485.2 & 9.7 & 486.7 & 5.8 & 487 & 52 & 100.31 \\
\hline 493.2 & 8.5 & 486.8 & 5.9 & 502 & 39 & 98.70 \\
\hline 501.5 & 11 & 486.9 & 8.2 & 554 & 50 & 97.09 \\
\hline 499.5 & 10 & 487.1 & 6.9 & 561 & 50 & 97.52 \\
\hline 497.2 & 8.1 & 487.2 & 5.8 & 533 & 40 & 97.99 \\
\hline 492 & 7.6 & 487.5 & 5.2 & 525 & 31 & 99.09 \\
\hline 489.2 & 11 & 487.8 & 7 & 481 & 62 & 99.71 \\
\hline 491 & 12 & 488.1 & 6.5 & 502 & 67 & 99.41 \\
\hline 492.1 & 8.9 & 488.1 & 5.9 & 537 & 43 & 99.19 \\
\hline 487.3 & 8.2 & 488.2 & 5 & 480 & 38 & 100.18 \\
\hline 486.8 & 8.5 & 488.3 & 4.9 & 483 & 45 & 100.31 \\
\hline 495.3 & 9.9 & 488.5 & 5.8 & 528 & 50 & 98.63 \\
\hline 481 & 11 & 488.9 & 5.1 & 449 & 57 & 101.64 \\
\hline 489.7 & 8.8 & 488.9 & 6.3 & 507 & 42 & 99.84 \\
\hline 487.7 & 9.6 & 489.3 & 5.3 & 461 & 47 & 100.33 \\
\hline 487.8 & 8.5 & 489.5 & 5.7 & 480 & 40 & 100.35 \\
\hline 491.8 & 7.6 & 489.6 & 5.1 & 499 & 34 & 99.55 \\
\hline 494.7 & 8.9 & 489.6 & 5.3 & 526 & 40 & 98.97 \\
\hline 493.4 & 7.7 & 489.7 & 5.1 & 504 & 32 & 99.25 \\
\hline 494.8 & 9.5 & 489.7 & 5.6 & 516 & 49 & 98.97 \\
\hline 488 & 9.1 & 490 & 5.6 & 491 & 45 & 100.41 \\
\hline 95.5 & 7.4 & 490.1 & 6.4 & 527 & 38 & 98.91 \\
\hline
\end{tabular}




\begin{tabular}{|c|c|c|c|c|c|c|c|c|c|c|c|c|c|}
\hline 71 & 0.6286 & 0.011 & 0.07901 & 0.00085 & 0.05732 & 0.00077 & 495.1 & 6.8 & 490.2 & 5.1 & 501 & 30 & 99.01 \\
\hline 72 & 0.632 & 0.018 & 0.07914 & 0.00092 & 0.0578 & 0.0014 & 497 & 11 & 491 & 5.5 & 517 & 54 & 98.79 \\
\hline 73 & 0.636 & 0.016 & 0.07919 & 0.00092 & 0.0581 & 0.0014 & 499.1 & 10 & 491.2 & 5.5 & 529 & 51 & 98.42 \\
\hline 74 & 0.63 & 0.014 & 0.07919 & 0.00085 & 0.0575 & 0.0011 & 495.7 & 8.6 & 491.2 & 5.1 & 516 & 42 & 99.09 \\
\hline 75 & 0.632 & 0.014 & 0.07922 & 0.00082 & 0.0578 & 0.0011 & 496.8 & 8.5 & 491.4 & 4.9 & 529 & 41 & 98.91 \\
\hline 76 & 0.624 & 0.013 & 0.07923 & 0.001 & 0.05726 & 0.00079 & 492.2 & 8.3 & 491.5 & 6 & 502 & 31 & 99.86 \\
\hline 77 & 0.6228 & 0.012 & 0.07931 & 0.00083 & 0.05701 & 0.00092 & 491.4 & 7.8 & 492 & 4.9 & 487 & 36 & 100.12 \\
\hline 78 & 0.627 & 0.016 & 0.07937 & 0.00083 & 0.0579 & 0.0013 & 496.2 & 10 & 492.4 & 5 & 522 & 48 & 99.23 \\
\hline 79 & 0.6332 & 0.012 & 0.0794 & 0.00085 & 0.0575 & 0.00087 & 497.8 & 7.7 & 492.5 & 5.1 & 507 & 33 & 98.94 \\
\hline 80 & 0.618 & 0.013 & 0.07939 & 0.0009 & 0.0564 & 0.00097 & 488 & 8.1 & 492.5 & 5.4 & 468 & 40 & 100.92 \\
\hline 81 & 0.63 & 0.014 & 0.0793 & 0.00094 & 0.0579 & 0.0013 & 495.6 & 8.9 & 492.8 & 5.9 & 524 & 47 & 99.44 \\
\hline 82 & 0.641 & 0.016 & 0.07948 & 0.00086 & 0.059 & 0.0013 & 503 & 9.8 & 493 & 5.1 & 571 & 46 & 98.01 \\
\hline 83 & 0.638 & 0.016 & 0.07947 & 0.00099 & 0.05831 & 0.001 & 502.3 & 9.3 & 493 & 5.9 & 543 & 39 & 98.15 \\
\hline 84 & 0.629 & 0.018 & 0.07949 & 0.0011 & 0.0571 & 0.0013 & 494.7 & 11 & 493.1 & 6.4 & 492 & 51 & 99.68 \\
\hline 85 & 0.6344 & 0.013 & 0.07949 & 0.00096 & 0.05831 & 0.00082 & 498.7 & 7.8 & 493.1 & 5.7 & 545 & 32 & 98.88 \\
\hline 86 & 0.627 & 0.015 & 0.07949 & 0.00095 & 0.0572 & 0.0011 & 493.7 & 9.6 & 493.1 & 5.7 & 516 & 41 & 99.88 \\
\hline 87 & 0.6205 & 0.013 & 0.07956 & 0.00085 & 0.05648 & 0.00094 & 489.9 & 7.8 & 493.5 & 5.1 & 466 & 36 & 100.73 \\
\hline 88 & 0.619 & 0.015 & 0.07958 & 0.00077 & 0.0566 & 0.0012 & 488.8 & 9.3 & 493.6 & 4.6 & 467 & 46 & 100.98 \\
\hline 89 & 0.639 & 0.014 & 0.07961 & 0.00099 & 0.05828 & 0.001 & 501.5 & 8.7 & 493.8 & 5.9 & 537 & 39 & 98.46 \\
\hline 90 & 0.629 & 0.012 & 0.07963 & 0.00082 & 0.05688 & 0.00089 & 495.3 & 7.5 & 493.9 & 4.9 & 492 & 34 & 99.72 \\
\hline 91 & 0.623 & 0.014 & 0.07969 & 0.0011 & 0.05689 & 0.00089 & 491.6 & 8.5 & 494.2 & 6.3 & 483 & 35 & 100.53 \\
\hline 92 & 0.649 & 0.016 & 0.07975 & 0.0011 & 0.0585 & 0.0013 & 507.7 & 9.7 & 494.6 & 6.3 & 543 & 49 & 97.42 \\
\hline 93 & 0.6278 & 0.012 & 0.07984 & 0.00093 & 0.05769 & 0.00087 & 496.8 & 8.5 & 495.1 & 5.5 & 514 & 33 & 99.66 \\
\hline 94 & 0.652 & 0.021 & 0.07966 & 0.0011 & 0.0595 & 0.0016 & 509 & 13 & 495.5 & 7.1 & 577 & 58 & 97.35 \\
\hline 95 & 0.637 & 0.014 & 0.0799 & 0.0009 & 0.0578 & 0.0011 & 500.3 & 8.8 & 495.5 & 5.4 & 526 & 41 & 99.04 \\
\hline 96 & 0.615 & 0.015 & 0.0798 & 0.00092 & 0.0556 & 0.0013 & 486.3 & 9.4 & 495.6 & 5.7 & 435 & 54 & 101.91 \\
\hline 97 & 0.628 & 0.014 & 0.07995 & 0.00076 & 0.0572 & 0.0012 & 494.3 & 8.7 & 495.8 & 4.5 & 490 & 46 & 100.30 \\
\hline 98 & 0.644 & 0.016 & 0.07998 & 0.00088 & 0.0584 & 0.0012 & 505.9 & 9.5 & 496 & 5.3 & 539 & 45 & 98.04 \\
\hline 99 & 0.6251 & 0.012 & 0.08002 & 0.00084 & 0.05678 & 0.0009 & 492.8 & 7.8 & 496.2 & 5 & 483 & 36 & 100.69 \\
\hline 100 & 0.6242 & 0.012 & 0.08003 & 0.00083 & 0.05668 & 0.00096 & 492.3 & 7.6 & 496.3 & 4.9 & 474 & 38 & 100.81 \\
\hline 101 & 0.63 & 0.013 & 0.08022 & 0.00094 & 0.0569 & 0.0011 & 495.5 & 8.1 & 497.4 & 5.6 & 481 & 43 & 100.38 \\
\hline 102 & 0.638 & 0.013 & 0.08024 & 0.00097 & 0.05803 & 0.0008 & 501.1 & 8 & 497.5 & 5.8 & 532 & 29 & 99.28 \\
\hline 103 & 0.628 & 0.017 & 0.08027 & 0.00097 & 0.0567 & 0.0013 & 494.5 & 10 & 497.7 & 5.8 & 483 & 52 & 100.65 \\
\hline 104 & 0.626 & 0.015 & 0.08029 & 0.00089 & 0.05665 & 0.001 & 492.9 & 9.2 & 497.8 & 5.3 & 473 & 40 & 100.99 \\
\hline 105 & 0.64 & 0.017 & 0.0805 & 0.00092 & 0.0578 & 0.0013 & 501.8 & 10 & 499.1 & 5.5 & 534 & 48 & 99.46 \\
\hline 106 & 0.632 & 0.017 & 0.08053 & 0.00087 & 0.0571 & 0.0013 & 497.8 & 11 & 499.3 & 5.2 & 491 & 49 & 100.30 \\
\hline 107 & 0.641 & 0.013 & 0.08058 & 0.00098 & 0.05734 & 0.00084 & 502.4 & 8.3 & 499.6 & 5.8 & 501 & 32 & 99.44 \\
\hline 108 & 0.623 & 0.014 & 0.08061 & 0.0008 & 0.0566 & 0.0011 & 491.6 & 8.5 & 499.7 & 4.8 & 475 & 43 & 101.65 \\
\hline 109 & 0.63 & 0.017 & 0.08062 & 0.00084 & 0.0568 & 0.0012 & 495.7 & 10 & 499.8 & 5 & 480 & 47 & 100.83 \\
\hline 110 & 0.627 & 0.016 & 0.0806 & 0.0013 & 0.0567 & 0.0012 & 494 & 10 & 499.9 & 7.5 & 488 & 48 & 101.19 \\
\hline 111 & 0.6373 & 0.012 & 0.08065 & 0.00085 & 0.05734 & 0.00083 & 500.4 & 7.5 & 500 & 5.1 & 501 & 32 & 99.92 \\
\hline 112 & 0.631 & 0.016 & 0.08067 & 0.0009 & 0.0567 & 0.0013 & 496.4 & 9.9 & 500.1 & 5.4 & 489 & 48 & 100.75 \\
\hline 113 & 0.635 & 0.014 & 0.08068 & 0.0011 & 0.05682 & 0.00097 & 498.6 & 8.5 & 500.1 & 6.3 & 479 & 38 & 100.30 \\
\hline 114 & 0.639 & 0.017 & 0.08068 & 0.00086 & 0.0575 & 0.0013 & 501 & 10 & 500.2 & 5.1 & 508 & 52 & 99.84 \\
\hline 115 & 0.6274 & 0.012 & 0.08069 & 0.00089 & 0.05627 & 0.00094 & 494.2 & 7.6 & 500.2 & 5.3 & 458 & 37 & 101.21 \\
\hline 116 & 0.6411 & 0.012 & 0.08079 & 0.0008 & 0.0578 & 0.001 & 503.7 & 7.8 & 500.8 & 4.8 & 516 & 39 & 99.42 \\
\hline 117 & 0.637 & 0.016 & 0.08083 & 0.00087 & 0.0569 & 0.0011 & 499.8 & 9.7 & 501.1 & 5.2 & 482 & 44 & 100.26 \\
\hline 118 & 0.6319 & 0.012 & 0.08087 & 0.00079 & 0.05652 & 0.0009 & 497.1 & 7.6 & 501.3 & 4.7 & 468 & 35 & 100.84 \\
\hline 119 & 0.636 & 0.013 & 0.08103 & 0.0009 & 0.0572 & 0.0011 & 499.6 & 8.3 & 502.2 & 5.4 & 497 & 40 & 100.52 \\
\hline 120 & 0.638 & 0.017 & 0.08108 & 0.00082 & 0.057 & 0.0013 & 500.3 & 11 & 502.5 & 4.9 & 480 & 52 & 100.44 \\
\hline 121 & 0.6403 & 0.012 & 0.08112 & 0.00078 & 0.05668 & 0.00087 & 502.3 & 7.2 & 502.8 & 4.6 & 480 & 35 & 100.10 \\
\hline 122 & 0.656 & 0.014 & 0.08115 & 0.0009 & 0.05827 & 0.001 & 512.2 & 8.7 & 503 & 5.4 & 545 & 37 & 98.20 \\
\hline 123 & 0.654 & 0.016 & 0.0812 & 0.0012 & 0.0589 & 0.0013 & 510.8 & 10 & 503.1 & 6.9 & 565 & 47 & 98.49 \\
\hline
\end{tabular}




\begin{tabular}{|c|c|c|}
\hline 124 & 0.636 & 01 \\
\hline 125 & 0.642 & 01 \\
\hline 26 & 0.6448 & 001 \\
\hline 27 & 0.644 & .02 \\
\hline 28 & 0.668 & .03 \\
\hline 29 & 0.647 & \\
\hline 30 & 0.653 & .01 \\
\hline 31 & 0.631 & 0.01 \\
\hline 32 & 0.651 & 0.01 \\
\hline 33 & 0.646 & 0.01 \\
\hline 34 & 0.631 & 0.02 \\
\hline 35 & 0.643 & 0.01 \\
\hline 36 & 0.645 & 0.01 \\
\hline 37 & 0.6489 & 0.01 \\
\hline 38 & 0.665 & 0.01 \\
\hline 139 & 0.6535 & 0.01 \\
\hline 140 & 0.678 & 0.01 \\
\hline 141 & 0.6487 & 0.01 \\
\hline 142 & 0.65 & 0.01 \\
\hline 143 & 0.665 & 0.01 \\
\hline 144 & 0.65 & ח 0 \\
\hline 1 & 0.664 & 0.01 \\
\hline 146 & 0.664 & 0.01 \\
\hline 147 & 0.67 & 0.016 \\
\hline 148 & 0.656 & 0.01 \\
\hline 149 & 0.669 & 0.01 \\
\hline 150 & 0.673 & c \\
\hline 151 & 0.663 & 0.0 \\
\hline 152 & 0.747 & 0.0 \\
\hline 153 & 0.767 & 0.0 \\
\hline & & \\
\hline
\end{tabular}

\begin{tabular}{rrrr}
0.08124 & 0.00094 & 0.05666 & 0.001 \\
0.08127 & 0.00098 & 0.0577 & 0.0012 \\
0.08139 & 0.00097 & 0.05753 & 0.00079 \\
0.08143 & 0.00086 & 0.0574 & 0.0018 \\
0.0814 & 0.0012 & 0.0593 & 0.0029 \\
0.08155 & 0.00098 & 0.05782 & 0.00087 \\
0.08172 & 0.00092 & 0.05759 & 0.00096 \\
0.08175 & 0.001 & 0.0563 & 0.0012 \\
0.0818 & 0.0012 & 0.05769 & 0.00088 \\
0.08178 & 0.00087 & 0.0574 & 0.0014 \\
0.0818 & 0.0012 & 0.0562 & 0.0027 \\
0.08183 & 0.001 & 0.0571 & 0.0016 \\
0.08185 & 0.001 & 0.0566 & 0.0011 \\
0.08198 & 0.0011 & 0.05732 & 0.00087 \\
0.08203 & 0.00098 & 0.0587 & 0.0011 \\
0.08218 & 0.00082 & 0.05807 & 0.00077 \\
0.08232 & 0.00091 & 0.0599 & 0.0011 \\
0.08251 & 0.00083 & 0.05663 & 0.00079 \\
0.08251 & 0.0011 & 0.0574 & 0.0014 \\
0.08267 & 0.00094 & 0.059 & 0.0013 \\
0.0828 & 0.00092 & 0.057 & 0.0012 \\
0.08321 & 0.00095 & 0.0578 & 0.0011 \\
0.0838 & 0.00093 & 0.0576 & 0.0011 \\
0.084 & 0.0012 & 0.0583 & 0.0009 \\
0.084 & 0.0012 & 0.0572 & 0.0015 \\
0.08435 & 0.00084 & 0.0577 & 0.001 \\
0.0844 & 0.0012 & 0.058 & 0.0014 \\
0.0846 & 0.0013 & 0.0578 & 0.0014 \\
0.09142 & 0.0011 & 0.059 & 0.0014 \\
0.09309 & 0.0012 & 0.0599 & 0.0014 \\
0.0993 & 0.0016 & 0.0622 & 0.0022 \\
& & & \\
\hline
\end{tabular}

$\begin{array}{rrrrrrr}499.3 & 8.5 & 503.5 & 5.6 & 472 & 40 & 100.84 \\ 503.2 & 10 & 503.7 & 5.9 & 511 & 47 & 100.10 \\ 505 & 7.9 & 504.4 & 5.8 & 509 & 30 & 99.88 \\ 504 & 13 & 504.6 & 5.2 & 508 & 65 & 100.12 \\ 523 & 24 & 504.8 & 6.9 & 627 & 100 & 96.52 \\ 507.4 & 8.6 & 505.3 & 5.9 & 519 & 33 & 99.59 \\ 510.3 & 8.4 & 506.3 & 5.5 & 510 & 36 & 99.22 \\ 496.3 & 8.2 & 506.5 & 6.1 & 456 & 46 & 102.06 \\ 508.7 & 8.8 & 506.6 & 7 & 519 & 35 & 99.59 \\ 506.6 & 10 & 506.7 & 5.2 & 501 & 56 & 100.02 \\ 496 & 17 & 506.8 & 7.1 & 450 & 110 & 102.18 \\ 504 & 12 & 507 & 6 & 512 & 62 & 100.60 \\ 506.1 & 10 & 507.1 & 6.2 & 475 & 41 & 100.20 \\ 507.6 & 7.3 & 507.9 & 6.5 & 506 & 32 & 100.06 \\ 517.6 & 9 & 508.2 & 5.8 & 558 & 43 & 98.18 \\ 510.4 & 7.6 & 509.7 & 5 & 533 & 30 & 99.86 \\ 525.5 & 8.9 & 509.9 & 5.4 & 603 & 38 & 97.03 \\ 507.5 & 7.5 & 511.1 & 4.9 & 483 & 33 & 100.71 \\ 508.1 & 11 & 511.1 & 6.3 & 516 & 54 & 100.59 \\ 517.4 & 9.3 & 512 & 5.6 & 570 & 47 & 98.96 \\ 508.1 & 9.2 & 512.8 & 5.5 & 499 & 43 & 100.93 \\ 516.6 & 9 & 515.2 & 5.6 & 530 & 42 & 99.73 \\ 516.4 & 9.4 & 518.7 & 5.5 & 515 & 44 & 100.45 \\ 520.6 & 8.6 & 519.7 & 7 & 539 & 34 & 99.83 \\ 514 & 12 & 520 & 7.2 & 489 & 57 & 101.17 \\ 519.7 & 8.5 & 522 & 5 & 518 & 39 & 100.44 \\ 522 & 12 & 522.5 & 7.4 & 525 & 54 & 100.10 \\ 511 & 11 & 563.9 & 6.4 & 571 & 49 & 99.61 \\ 513 & 573.8 & 6.8 & 592 & 52 & 99.10 \\ 517.7 & 610.4 & 9.3 & 657 & 76 & 98.29\end{array}$

15DL9, rhyolite, Group I (Ediacaran)

\begin{tabular}{|c|c|c|c|c|c|c|c|c|c|c|c|c|c|}
\hline \multicolumn{7}{|c|}{ \# Isotopic ratios (and $2 \sigma$ errors) } & \multicolumn{6}{|c|}{ Isotopic ages (and $2 \sigma$ erros) } & \multirow[t]{2}{*}{ Disc. } \\
\hline & $207 \mathrm{~Pb} /$ & & $206 \mathrm{~Pb} /$ & & $207 \mathrm{~Pb} /$ & & $207 \mathrm{~Pb} /$ & & 206Pb/ & & $7 \mathrm{~Pb} /$ & & \\
\hline & $235 \mathrm{U}$ & $\% \pm$ & $238 \mathrm{U}$ & $\% \pm$ & $206 \mathrm{~Pb}$ & $\% \pm$ & $235 \mathrm{U}$ & \pm & $238 U$ & & $6 / \mathrm{Pb}$ & \pm & $\%$ \\
\hline 155 & 0.645 & 0.017 & 0.08011 & 0.0011 & 0.059 & 0.0015 & 508.5 & 10 & 496.8 & 6.4 & 560 & 54 & 97.70 \\
\hline 156 & 0.653 & 0.014 & 0.08189 & 0.00088 & 0.0574 & 0.0011 & 509.9 & 8.3 & 507.4 & 5.2 & 509 & 40 & 99.51 \\
\hline 157 & 0.71 & 0.015 & 0.0871 & 0.00097 & 0.0589 & 0.0012 & 544.2 & 8.9 & 538.3 & 5.8 & 569 & 41 & 98.92 \\
\hline 158 & 0.744 & 0.042 & 0.0876 & 0.0021 & 0.0619 & 0.0038 & 563 & 25 & 541 & 12 & 630 & 130 & 96.09 \\
\hline 159 & 0.725 & 0.018 & 0.08955 & 0.0011 & 0.0587 & 0.0014 & 552.8 & 11 & 552.9 & 6.5 & 568 & 51 & 100.02 \\
\hline 160 & 0.73 & 0.015 & 0.0896 & 0.001 & 0.0592 & 0.0011 & 556.1 & 8.9 & 553.1 & 5.9 & 579 & 41 & 99.46 \\
\hline 161 & 0.73 & 0.017 & 0.08972 & 0.00096 & 0.0592 & 0.0014 & 556 & 10 & 553.8 & 5.7 & 579 & 48 & 99.60 \\
\hline 162 & 0.735 & 0.014 & 0.09003 & 0.001 & 0.05926 & 0.00089 & 560.3 & 8.2 & 555.7 & 6.2 & 577 & 32 & 99.18 \\
\hline 163 & 0.733 & 0.016 & 0.0901 & 0.0013 & 0.05886 & 0.00092 & 558.1 & 9.5 & 556.3 & 7.6 & 567 & 32 & 99.68 \\
\hline 164 & 0.712 & 0.015 & 0.0902 & 0.0016 & 0.0584 & 0.0014 & 547.9 & 10 & 557 & 9.7 & 541 & 51 & 101.66 \\
\hline 165 & 0.742 & 0.022 & 0.0907 & 0.00095 & 0.0588 & 0.0016 & 563 & 13 & 559.7 & 5.6 & 555 & 58 & 99.41 \\
\hline 166 & 0.729 & 0.015 & 0.09073 & 0.0011 & 0.05817 & 0.00094 & 555.7 & 8.5 & 559.8 & 6.6 & 537 & 37 & 100.74 \\
\hline 167 & 0.757 & 0.023 & 0.0908 & 0.0013 & 0.0604 & 0.0014 & 572 & 13 & 560.1 & 7.5 & 615 & 49 & 97.92 \\
\hline 168 & 0.749 & 0.017 & 0.09134 & 0.001 & 0.0596 & 0.0013 & 568.3 & 10 & 563.4 & 6.2 & 580 & 49 & 99.14 \\
\hline
\end{tabular}




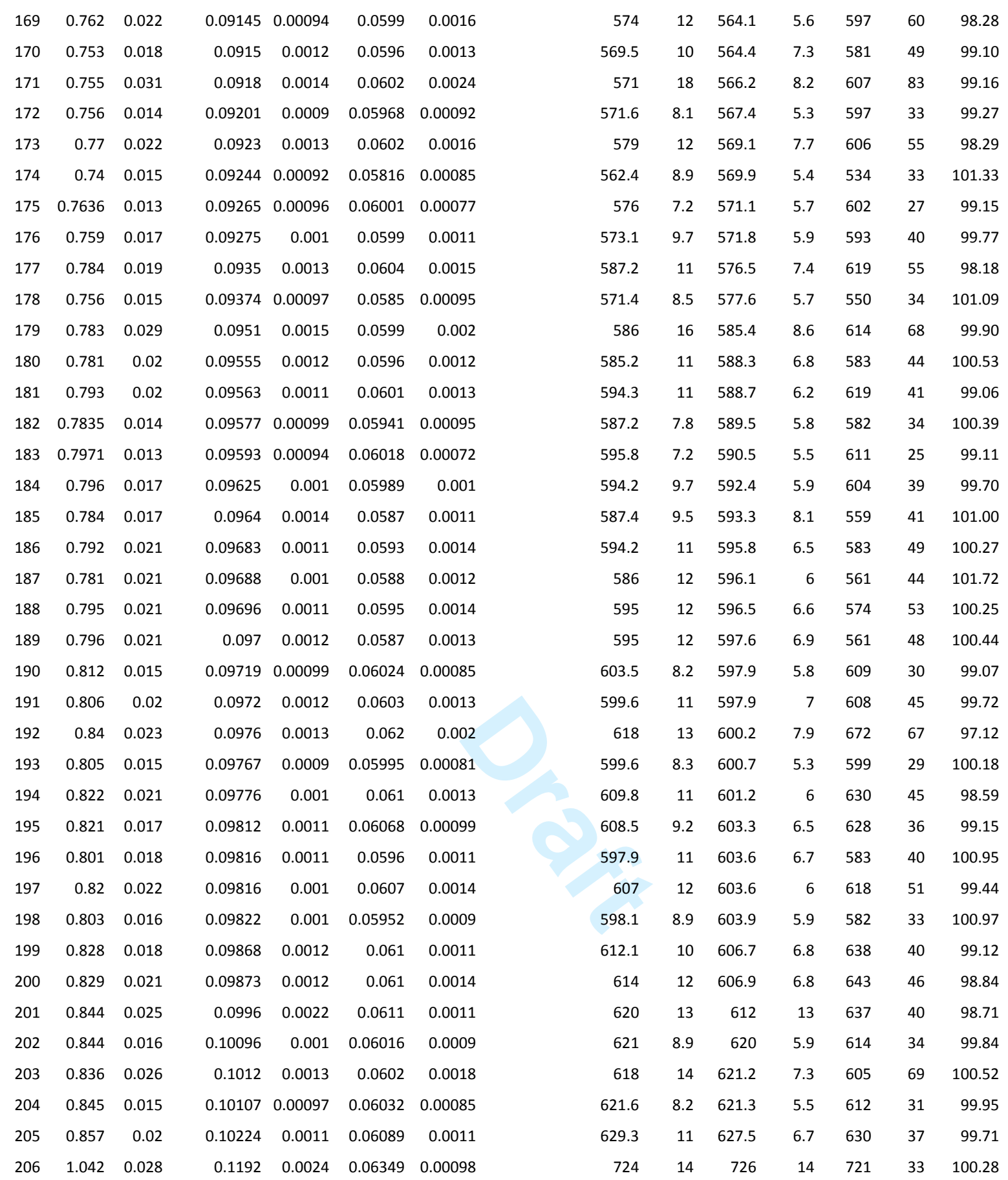

15DL11, matrix of metaconglomerate, Group I (upper Ediacaran/lower Cambrian)

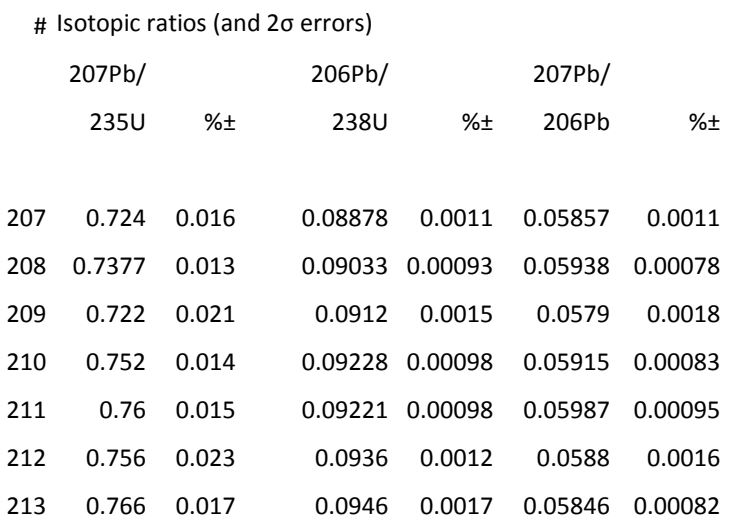

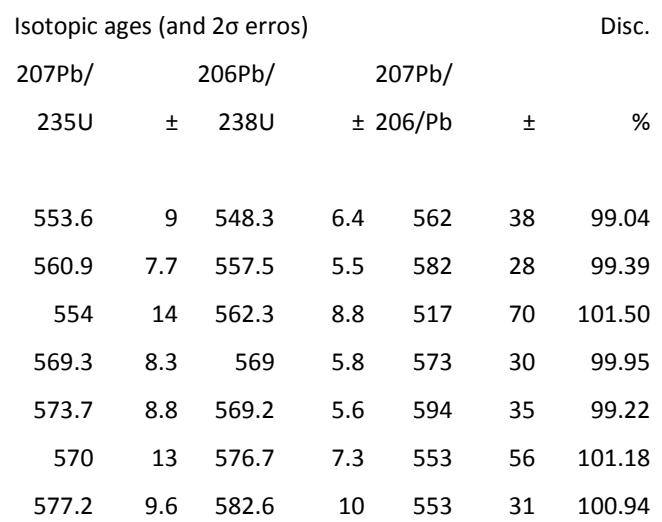




$\begin{array}{rrrrrrr}214 & 0.78 & 0.014 & 0.09593 & 0.001 & 0.05927 & 0.00092 \\ 215 & 0.813 & 0.016 & 0.09751 & 0.0011 & 0.0603 & 0.00099 \\ 216 & 0.827 & 0.016 & 0.098 & 0.0012 & 0.0614 & 0.001 \\ 217 & 0.824 & 0.015 & 0.09954 & 0.00099 & 0.05979 & 0.0011 \\ 218 & 0.838 & 0.017 & 0.0996 & 0.0013 & 0.0611 & 0.0012 \\ 219 & 0.866 & 0.024 & 0.10158 & 0.0012 & 0.0615 & 0.0014\end{array}$

$\begin{array}{rrrrrrr}585.3 & 8.2 & 590.5 & 5.9 & 577 & 33 & 100.89 \\ 604.8 & 9.2 & 599.8 & 6.3 & 610 & 35 & 99.17 \\ 612.7 & 9.5 & 602.9 & 7.3 & 648 & 36 & 98.40 \\ 610 & 8 & 611.7 & 5.8 & 591 & 38 & 100.28 \\ 617.7 & 9.7 & 613.1 & 7.3 & 635 & 41 & 99.26 \\ 634 & 13 & 623.7 & 7.1 & 656 & 51 & 98.38\end{array}$

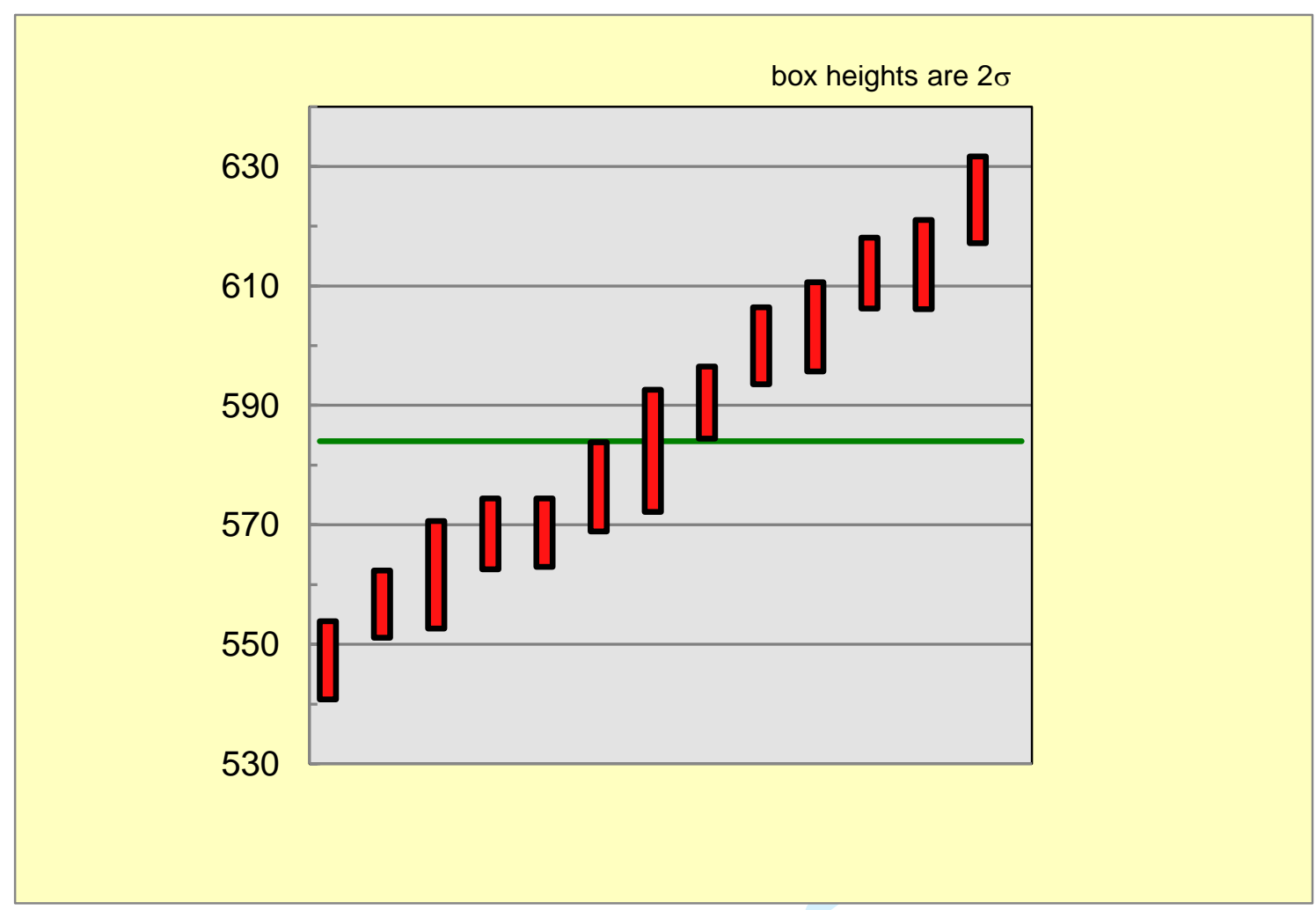

15DL12, quartz sandstone ("El Hank quartzite"), Group IV (upper Cambrian)

\begin{tabular}{|c|c|c|c|c|c|c|c|c|c|c|c|c|c|}
\hline \multicolumn{7}{|c|}{ \# Isotopic ratios (and $2 \sigma$ errors) } & \multicolumn{6}{|c|}{ Isotopic ages (and $2 \sigma$ erros) } & \multirow[t]{2}{*}{ Disc. } \\
\hline & $207 \mathrm{~Pb} /$ & & $206 \mathrm{~Pb} /$ & & $207 \mathrm{~Pb} /$ & & $207 \mathrm{~Pb} /$ & & $206 \mathrm{~Pb} /$ & & $07 \mathrm{~Pb} /$ & & \\
\hline & $235 \mathrm{U}$ & $\% \pm$ & $238 U$ & $\% \pm$ & $206 \mathrm{~Pb}$ & $\% \pm$ & $235 \mathrm{U}$ & \pm & $238 \mathrm{U}$ & & $06 / \mathrm{Pb}$ & \pm & $\%$ \\
\hline 220 & 0.815 & 0.022 & 0.09676 & 0.0012 & 0.0608 & 0.0015 & 607 & 12 & 595.4 & 6.8 & 639 & 51 & 98.09 \\
\hline 221 & 0.99 & 0.026 & 0.111 & 0.0016 & 0.0641 & 0.0015 & 698 & 14 & 678.6 & 9.1 & 739 & 51 & 97.22 \\
\hline 222 & 1.742 & 0.034 & 0.1714 & 0.002 & 0.07394 & 0.001 & 1023.6 & 13 & 1019.7 & 11 & 1041 & 28 & 99.62 \\
\hline 223 & 0.809 & 0.029 & 0.0971 & 0.0014 & 0.06 & 0.0019 & 600 & 16 & 597.5 & 8.2 & 593 & 72 & 99.58 \\
\hline 224 & 6.282 & 0.097 & 0.37 & 0.0042 & 0.1231 & 0.0013 & 2015.5 & 14 & 2029 & 20 & 2001 & 19 & 100.67 \\
\hline 225 & 0.812 & 0.024 & 0.0996 & 0.0015 & 0.0591 & 0.0017 & 603 & 13 & 611.8 & 9 & 563 & 62 & 101.46 \\
\hline 226 & 0.837 & 0.025 & 0.0985 & 0.0012 & 0.0621 & 0.0015 & 616 & 14 & 605.7 & 7.3 & 681 & 55 & 98.33 \\
\hline 227 & 4.64 & 0.1 & 0.315 & 0.0046 & 0.1082 & 0.0019 & 1760 & 18 & 1765 & 23 & 1771 & 31 & 100.28 \\
\hline 228 & 0.988 & 0.028 & 0.1178 & 0.0022 & 0.062 & 0.0015 & 699 & 13 & 718 & 13 & 664 & 52 & 102.72 \\
\hline 229 & 7.084 & 0.11 & 0.3923 & 0.0046 & 0.1309 & 0.0014 & 2121.4 & 14 & 2133 & 21 & 2111 & 19 & 100.55 \\
\hline 230 & 4.608 & 0.078 & 0.3118 & 0.0034 & 0.1076 & 0.0013 & 1750.1 & 14 & 1750 & 17 & 1764 & 23 & 99.99 \\
\hline 231 & 0.863 & 0.019 & 0.1036 & 0.0014 & 0.0605 & 0.0012 & 631.1 & 11 & 635.3 & 8 & 620 & 41 & 100.67 \\
\hline 232 & 5.13 & 0.15 & 0.3339 & 0.0049 & 0.1117 & 0.003 & 1838 & 24 & 1857 & 24 & 1831 & 46 & 101.03 \\
\hline 233 & 6.49 & 0.18 & 0.3761 & 0.0054 & 0.1249 & 0.0028 & 2043 & 24 & 2058 & 25 & 2023 & 40 & 100.73 \\
\hline 234 & 6.325 & 0.11 & 0.3675 & 0.0044 & 0.1242 & 0.0013 & 2021 & 16 & 2017 & 21 & 2016 & 19 & 99.80 \\
\hline
\end{tabular}




\begin{tabular}{|c|c|c|c|c|c|c|c|c|c|c|c|c|c|}
\hline 235 & 0.824 & 0.019 & 0.09738 & 0.001 & 0.0608 & 0.0012 & 609.8 & 11 & 599 & 6 & 624 & 44 & 98.23 \\
\hline 236 & 0.816 & 0.029 & 0.0987 & 0.0016 & 0.0601 & 0.0019 & 604 & 16 & 606.5 & 9.2 & 588 & 70 & 100.41 \\
\hline 237 & 0.786 & 0.02 & 0.09408 & 0.0011 & 0.0601 & 0.0013 & 588.6 & 11 & 579.6 & 6.5 & 599 & 48 & 98.47 \\
\hline 238 & 0.798 & 0.021 & 0.09645 & 0.0011 & 0.0602 & 0.0014 & 596 & 12 & 593.6 & 6.4 & 613 & 51 & 99.60 \\
\hline 239 & 5.09 & 0.15 & 0.3236 & 0.0043 & 0.1143 & 0.003 & 1833 & 25 & 1807 & 21 & 1873 & 51 & 98.58 \\
\hline 240 & 0.872 & 0.018 & 0.10367 & 0.0012 & 0.06078 & 0.00094 & 636.2 & 9.8 & 635.9 & 7 & 636 & 35 & 99.95 \\
\hline 241 & 0.874 & 0.021 & 0.1053 & 0.0013 & 0.0602 & 0.0013 & 637 & 12 & 645.1 & 7.4 & 600 & 49 & 101.27 \\
\hline 242 & 7.04 & 0.17 & 0.3937 & 0.0054 & 0.1298 & 0.0021 & 2117 & 22 & 2140 & 25 & 2095 & 28 & 101.09 \\
\hline 243 & 0.851 & 0.023 & 0.0999 & 0.0013 & 0.0618 & 0.0016 & 626 & 12 & 613.8 & 7.5 & 652 & 58 & 98.05 \\
\hline 244 & 7.177 & 0.11 & 0.3897 & 0.0045 & 0.13419 & 0.0012 & 2133.2 & 14 & 2121 & 21 & 2153 & 16 & 99.43 \\
\hline 245 & 6.167 & 0.091 & 0.3643 & 0.0035 & 0.12264 & 0.0011 & 1999.5 & 13 & 2002 & 17 & 1994 & 16 & 100.13 \\
\hline 246 & 0.82 & 0.018 & 0.0971 & 0.0013 & 0.0614 & 0.0013 & 607.9 & 9.7 & 597.6 & 7.6 & 649 & 46 & 98.31 \\
\hline 247 & 1.418 & 0.041 & 0.151 & 0.002 & 0.0673 & 0.0016 & 895 & 17 & 906.2 & 11 & 863 & 49 & 101.25 \\
\hline 248 & 0.802 & 0.026 & 0.0989 & 0.0012 & 0.0585 & 0.0016 & 599 & 14 & 607.9 & 7 & 550 & 63 & 101.49 \\
\hline 249 & 0.839 & 0.021 & 0.10151 & 0.0012 & 0.06 & 0.0012 & 618 & 12 & 623.2 & 7.2 & 597 & 44 & 100.84 \\
\hline 250 & 0.909 & 0.025 & 0.1094 & 0.0017 & 0.0602 & 0.0013 & 655 & 13 & 669.1 & 9.9 & 601 & 48 & 102.15 \\
\hline 251 & 5.803 & 0.088 & 0.3543 & 0.0038 & 0.1191 & 0.0011 & 1946.4 & 13 & 1955 & 18 & 1944 & 17 & 100.44 \\
\hline 252 & 0.945 & 0.02 & 0.1122 & 0.0013 & 0.0606 & 0.0012 & 675.2 & 10 & 685.5 & 7.3 & 638 & 47 & 101.53 \\
\hline 253 & 0.759 & 0.023 & 0.09307 & 0.0011 & 0.0593 & 0.0016 & 572 & 13 & 573.6 & 6.4 & 579 & 58 & 100.28 \\
\hline 254 & 13.4 & 0.27 & 0.5187 & 0.0068 & 0.1866 & 0.003 & 2710 & 18 & 2693 & 29 & 2716 & 26 & 99.37 \\
\hline 255 & 1.996 & 0.084 & 0.1882 & 0.0034 & 0.0766 & 0.0028 & 1109 & 28 & 1112 & 19 & 1098 & 73 & 100.27 \\
\hline 256 & 6.071 & 0.11 & 0.3573 & 0.0042 & 0.1225 & 0.0016 & 1987 & 15 & 1969 & 20 & 1995 & 22 & 99.09 \\
\hline 257 & 6.75 & 0.14 & 0.3785 & 0.0057 & 0.1305 & 0.0015 & 2081 & 18 & 2069 & 26 & 2104 & 20 & 99.42 \\
\hline 258 & 0.872 & 0.016 & 0.10265 & 0.0011 & 0.0616 & 0.0009 & 636.3 & 8.4 & 629.9 & 6.6 & 657 & 31 & 98.99 \\
\hline 259 & 6.273 & 0.1 & 0.3648 & 0.0037 & 0.1256 & 0.0015 & 2014.2 & 14 & 2005 & 17 & 2036 & 22 & 99.54 \\
\hline 260 & 0.807 & 0.016 & 0.09712 & 0.0011 & 0.06005 & 0.00095 & 600.2 & 9.1 & 597.5 & 6.2 & 615 & 34 & 99.55 \\
\hline 261 & 0.875 & 0.022 & 0.1015 & 0.0014 & 0.0624 & 0.0014 & 638 & 12 & 623.1 & 8 & 691 & 45 & 97.66 \\
\hline 262 & 0.7938 & 0.014 & 0.09617 & 0.0011 & 0.05987 & 0.00081 & 593.1 & 7.8 & 591.9 & 6.3 & 596 & 29 & 99.80 \\
\hline 263 & 0.828 & 0.02 & 0.0979 & 0.0012 & 0.0609 & 0.0014 & 612.4 & 11 & 602 & 7.1 & 655 & 49 & 98.30 \\
\hline 264 & 0.938 & 0.017 & 0.1102 & 0.0014 & 0.06194 & 0.00085 & 671.5 & 8.7 & 673.6 & 7.9 & 669 & 29 & 100.31 \\
\hline 265 & 0.781 & 0.026 & 0.0958 & 0.0012 & 0.0591 & 0.0018 & 587 & 14 & 589.7 & 6.8 & 551 & 68 & 100.46 \\
\hline 266 & 0.828 & 0.02 & 0.10052 & 0.0012 & 0.0597 & 0.0012 & 613.7 & 11 & 617.4 & 6.8 & 600 & 42 & 100.60 \\
\hline 267 & 0.858 & 0.023 & 0.1042 & 0.0013 & 0.0601 & 0.0015 & 630 & 12 & 638.8 & 7.6 & 605 & 55 & 101.40 \\
\hline 268 & 0.878 & 0.018 & 0.10426 & 0.0011 & 0.06139 & 0.00096 & 641.9 & 9.1 & 639.3 & 6.2 & 653 & 33 & 99.59 \\
\hline 269 & 0.822 & 0.023 & 0.09637 & 0.0012 & 0.0606 & 0.0015 & 608 & 13 & 593.1 & 6.9 & 649 & 55 & 97.55 \\
\hline 270 & 6.269 & 0.091 & 0.3665 & 0.0037 & 0.12364 & 0.0012 & 2013.9 & 13 & 2015 & 18 & 2009 & 18 & 100.05 \\
\hline 271 & 9.4 & 0.17 & 0.4466 & 0.0067 & 0.1542 & 0.002 & 2377 & 17 & 2379 & 30 & 2392 & 22 & 100.08 \\
\hline 272 & 0.833 & 0.032 & 0.1035 & 0.0016 & 0.0578 & 0.0022 & 616 & 17 & 634.9 & 9.4 & 506 & 85 & 103.07 \\
\hline 273 & 6.424 & 0.096 & 0.3723 & 0.0036 & 0.12534 & 0.0011 & 2036.2 & 13 & 2040 & 17 & 2035 & 16 & 100.19 \\
\hline 274 & 6.499 & 0.12 & 0.3745 & 0.0057 & 0.12575 & 0.0013 & 2045 & 17 & 2050 & 27 & 2039 & 18 & 100.24 \\
\hline 275 & 0.8249 & 0.014 & 0.09838 & 0.0011 & 0.06072 & 0.00075 & 610.6 & 7.9 & 604.9 & 6.3 & 627 & 26 & 99.07 \\
\hline 276 & 4.88 & 0.12 & 0.3159 & 0.0048 & 0.1119 & 0.0022 & 1797 & 21 & 1769 & 23 & 1832 & 35 & 98.44 \\
\hline 277 & 0.791 & 0.038 & 0.0964 & 0.0017 & 0.0589 & 0.003 & 592 & 21 & 592.9 & 9.8 & 540 & 110 & 100.15 \\
\hline 278 & 13.74 & 0.24 & 0.5243 & 0.0054 & 0.1897 & 0.0019 & 2731 & 17 & 2717 & 23 & 2739 & 16 & 99.49 \\
\hline 279 & 0.888 & 0.026 & 0.1069 & 0.0013 & 0.0601 & 0.0017 & 645 & 14 & 654.9 & 7.8 & 603 & 60 & 101.53 \\
\hline 280 & 0.76 & 0.025 & 0.09333 & 0.0011 & 0.0587 & 0.0019 & 573 & 14 & 575.2 & 6.6 & 554 & 74 & 100.38 \\
\hline 281 & 0.862 & 0.016 & 0.10157 & 0.0011 & 0.06155 & 0.00082 & 630.7 & 8.8 & 623.6 & 6.4 & 656 & 29 & 98.87 \\
\hline 282 & 6.673 & 0.11 & 0.3776 & 0.004 & 0.1275 & 0.0014 & 2068.4 & 15 & 2065 & 19 & 2068 & 18 & 99.84 \\
\hline 283 & 5.12 & 0.11 & 0.33 & 0.0045 & 0.1123 & 0.002 & 1838 & 18 & 1838 & 22 & 1844 & 33 & 100.00 \\
\hline 284 & 6.778 & 0.1 & 0.3797 & 0.0039 & 0.12964 & 0.0012 & 2083.7 & 14 & 2077 & 18 & 2092 & 16 & 99.68 \\
\hline 285 & 6.19 & 0.18 & 0.3627 & 0.0058 & 0.1251 & 0.0035 & 2000 & 25 & 1998 & 28 & 2026 & 48 & 99.90 \\
\hline 286 & 6.01 & 0.15 & 0.3637 & 0.0065 & 0.1205 & 0.0026 & 1979 & 23 & 1999 & 31 & 1961 & 39 & 101.01 \\
\hline 287 & 0.791 & 0.019 & 0.09729 & 0.0011 & 0.0591 & 0.0013 & 591 & 11 & 598.5 & 6.6 & 569 & 48 & 101.27 \\
\hline
\end{tabular}




$\begin{array}{rrrrrrr}288 & 0.913 & 0.033 & 0.1099 & 0.0015 & 0.0602 & 0.0022 \\ 289 & 1.017 & 0.022 & 0.1169 & 0.0015 & 0.06345 & 0.00096 \\ 290 & 5.84 & 0.19 & 0.3466 & 0.0063 & 0.1232 & 0.0045 \\ 291 & 6.389 & 0.11 & 0.3687 & 0.0043 & 0.1254 & 0.0014\end{array}$

$\begin{array}{rrrrrrr}659 & 18 & 671.9 & 8.8 & 610 & 76 & 101.96 \\ 714.6 & 11 & 712.8 & 8.4 & 720 & 32 & 99.75 \\ 1954 & 28 & 1918 & 30 & 2011 & 63 & 98.16 \\ 2031.6 & 15 & 2023 & 20 & 2034 & 20 & 99.58\end{array}$

\section{Data not used for calculations and plots}

\section{DL1, rhyolite, Group I (Ediacaran)}

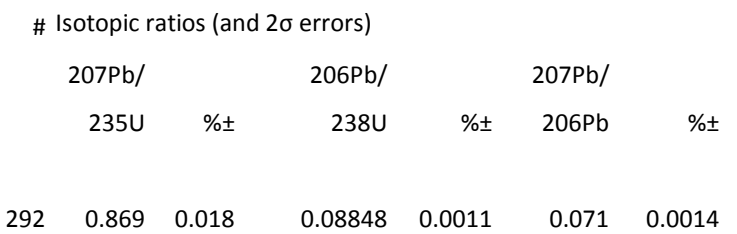

Isotopic ages (and $2 \sigma$ erros)

Disc.

207Pb/206Pb/ 207Pb/

$235 \mathrm{U} \pm 238 \mathrm{U} \quad \pm 206 / \mathrm{Pb} \quad \pm \quad \%$

$\begin{array}{lllllll}637.2 & 9.8 & 546.5 & 6.3 & 963 & 39 & 85.77\end{array}$

15DL6, greywacke, Group III (upper Cambrian)

\begin{tabular}{|c|c|c|c|c|c|c|c|c|c|c|c|c|c|}
\hline \multicolumn{7}{|c|}{ \# Isotopic ratios (and $2 \sigma$ errors) } & \multicolumn{6}{|c|}{ Isotopic ages (and $2 \sigma$ erros) } & Disc. \\
\hline & $207 \mathrm{~Pb} /$ & & $206 \mathrm{~Pb} /$ & & $207 \mathrm{~Pb} /$ & & $207 \mathrm{~Pb} /$ & & $206 \mathrm{~Pb} /$ & & $07 \mathrm{~Pb} /$ & & \\
\hline & $235 \mathrm{U}$ & $\% \pm$ & $238 \mathrm{U}$ & $\% \pm$ & $206 \mathrm{~Pb}$ & $\% \pm$ & $235 \mathrm{U}$ & \pm & $238 \mathrm{U}$ & & $06 / \mathrm{Pb}$ & \pm & $\%$ \\
\hline 293 & 0.6442 & 0.01 & 0.0635 & 0.0021 & 0.0743 & 0.0027 & 504.8 & 6.5 & 397 & 13 & 1045 & 72 & 78.65 \\
\hline 294 & 0.7696 & 0.013 & 0.02392 & 0.00034 & 0.2358 & 0.0046 & 579.4 & 7.5 & 152.4 & 2.1 & 3092 & 31 & 26.30 \\
\hline 295 & 0.738 & 0.017 & 0.07792 & 0.00085 & 0.0687 & 0.0014 & 560.6 & 9.7 & 483.7 & 5.1 & 883 & 41 & 86.28 \\
\hline 296 & 1.018 & 0.046 & 0.08277 & 0.00096 & 0.0889 & 0.0034 & 709 & 23 & 512.6 & 5.7 & 1387 & 74 & 72.30 \\
\hline 297 & 0.785 & 0.038 & 0.0633 & 0.0042 & 0.096 & 0.011 & 586 & 21 & 395 & 25 & 1430 & 210 & 67.41 \\
\hline 298 & 1.58 & 0.52 & 0.084 & 0.0047 & 0.123 & 0.031 & 840 & 160 & 519 & 27 & 1690 & 390 & 61.79 \\
\hline 299 & 0.679 & 0.016 & 0.07769 & 0.00088 & 0.0629 & 0.0014 & 527.2 & 9.9 & 482.3 & 5.3 & 710 & 48 & 91.48 \\
\hline 300 & 2.16 & 0.25 & 0.0899 & 0.0021 & 0.167 & 0.016 & 1138 & 80 & 555 & 13 & 2430 & 160 & 48.77 \\
\hline 301 & 0.849 & 0.025 & 0.0822 & 0.0013 & 0.075 & 0.0022 & 625 & 14 & 508.9 & 7.6 & 1064 & 57 & 81.42 \\
\hline 302 & 0.701 & 0.017 & 0.0608 & 0.0013 & 0.0839 & 0.0026 & 539 & 10 & 380.2 & 8.1 & 1286 & 60 & 70.54 \\
\hline 303 & 0.6107 & 0.011 & 0.07222 & 0.00085 & 0.06127 & 0.00087 & 483.9 & 7 & 449.5 & 5.1 & 645 & 31 & 92.89 \\
\hline 304 & 1.82 & 0.18 & 0.08072 & 0.001 & 0.162 & 0.015 & 1027 & 59 & 500.4 & 6.1 & 2380 & 150 & 48.72 \\
\hline 305 & 0.6875 & 0.012 & 0.06774 & 0.001 & 0.07339 & 0.001 & 531.2 & 7.1 & 422.5 & 6.3 & 1025 & 29 & 79.54 \\
\hline 306 & 0.6075 & 0.012 & 0.06666 & 0.00089 & 0.06584 & 0.001 & 481.8 & 7.4 & 416 & 5.4 & 802 & 33 & 86.34 \\
\hline 307 & 0.781 & 0.014 & 0.06211 & 0.00081 & 0.0915 & 0.0012 & 586 & 8.1 & 388.4 & 4.9 & 1459 & 25 & 66.28 \\
\hline 308 & 0.902 & 0.024 & 0.0724 & 0.0016 & 0.0903 & 0.0038 & 654 & 13 & 450.7 & 9.3 & 1452 & 83 & 68.91 \\
\hline 309 & 2.52 & 0.44 & 0.0941 & 0.0034 & 0.18 & 0.026 & 1160 & 130 & 579 & 20 & 2290 & 290 & 49.91 \\
\hline 310 & 0.6784 & 0.012 & 0.07454 & 0.00095 & 0.06571 & 0.001 & 525.6 & 7.4 & 463.4 & 5.7 & 793 & 32 & 88.17 \\
\hline 311 & 0.7055 & 0.013 & 0.0746 & 0.0014 & 0.06826 & 0.001 & 541.9 & 7.9 & 464 & 8.2 & 873 & 31 & 85.62 \\
\hline 312 & 0.586 & 0.017 & 0.0712 & 0.0012 & 0.0605 & 0.0016 & 468 & 11 & 443.3 & 7.4 & 619 & 56 & 94.72 \\
\hline 313 & 0.693 & 0.026 & 0.0812 & 0.0024 & 0.0623 & 0.0024 & 534 & 16 & 503 & 14 & 677 & 82 & 94.19 \\
\hline 314 & 0.65 & 0.014 & 0.0689 & 0.0026 & 0.0694 & 0.0027 & 508 & 8.6 & 429 & 15 & 894 & 82 & 84.45 \\
\hline 315 & 0.669 & 0.013 & 0.03251 & 0.00044 & 0.1497 & 0.0018 & 519.9 & 7.6 & 206.2 & 2.7 & 2342 & 20 & 39.66 \\
\hline 316 & 0.6554 & 0.011 & 0.07457 & 0.00087 & 0.06374 & 0.00085 & 512.4 & 7.2 & 463.6 & 5.2 & 730 & 28 & 90.48 \\
\hline 317 & 0.606 & 0.023 & 0.0474 & 0.0046 & 0.1022 & 0.0089 & 483 & 14 & 298 & 28 & 1530 & 170 & 61.70 \\
\hline 318 & 0.555 & 0.013 & 0.0632 & 0.0017 & 0.0643 & 0.002 & 448 & 8.4 & 394.8 & 10 & 750 & 67 & 88.13 \\
\hline 319 & 0.4744 & 0.009 & 0.0388 & 0.0014 & 0.0892 & 0.0025 & 394.1 & 6.2 & 245.4 & 8.5 & 1404 & 53 & 62.27 \\
\hline 320 & 0.702 & 0.025 & 0.0819 & 0.0019 & 0.0629 & 0.0023 & 540 & 15 & 507 & 11 & 696 & 78 & 93.89 \\
\hline 321 & 4.05 & 0.95 & 0.1121 & 0.0095 & 0.217 & 0.037 & 1380 & 190 & 682 & 55 & 2510 & 310 & 49.42 \\
\hline 322 & 0.881 & 0.023 & 0.0457 & 0.0036 & 0.153 & 0.012 & 641 & 12 & 288 & 22 & 2330 & 140 & 44.93 \\
\hline
\end{tabular}




$\begin{array}{rrrrrrr}323 & 0.533 & 0.016 & 0.0599 & 0.0012 & 0.0652 & 0.0014 \\ 324 & 0.584 & 0.013 & 0.05075 & 0.0008 & 0.08347 & 0.00093 \\ 325 & 0.692 & 0.02 & 0.0594 & 0.0025 & 0.0868 & 0.0055 \\ 326 & 0.566 & 0.014 & 0.0626 & 0.0011 & 0.0659 & 0.0011 \\ 327 & 0.6298 & 0.01 & 0.05991 & 0.0011 & 0.077 & 0.0019 \\ 328 & 0.909 & 0.029 & 0.0682 & 0.0012 & 0.098 & 0.0041\end{array}$

$\begin{array}{rrrrrrr}433.5 & 10 & 375.1 & 7.1 & 778 & 43 & 86.53 \\ 466.7 & 8.2 & 319.1 & 4.9 & 1282 & 23 & 68.37 \\ 533 & 12 & 372 & 15 & 1310 & 120 & 69.79 \\ 455.2 & 9.2 & 391.4 & 6.7 & 802 & 35 & 85.98 \\ 495.9 & 6.5 & 375.1 & 6.4 & 1110 & 49 & 75.64 \\ 655 & 15 & 425 & 7.4 & 1557 & 80 & 64.89\end{array}$

15DL9, rhyolite, Group I (Ediacaran)

\begin{tabular}{|c|c|c|c|c|c|c|}
\hline & $207 \mathrm{~Pb} /$ & & $206 \mathrm{~Pb} /$ & \multicolumn{3}{|c|}{$207 \mathrm{~Pb} /$} \\
\hline & $235 \mathrm{U}$ & $\% \pm$ & $238 \mathrm{U}$ & $\% \pm$ & $206 \mathrm{~Pb}$ & $\% \pm$ \\
\hline 329 & 0.797 & 0.038 & 0.0907 & 0.0022 & 0.0639 & 0.003 \\
\hline 330 & 0.7545 & 0.013 & 0.08224 & 0.00099 & 0.06704 & 0.00088 \\
\hline 331 & 0.836 & 0.017 & 0.09786 & 0.0012 & 0.06138 & 0.00091 \\
\hline 332 & 0.7601 & 0.014 & 0.09099 & 0.001 & 0.06044 & 0.00088 \\
\hline 333 & 0.822 & 0.022 & 0.094 & 0.0011 & 0.0637 & 0.0014 \\
\hline 334 & 0.733 & 0.036 & 0.0848 & 0.0015 & 0.0634 & 0.0027 \\
\hline 335 & 0.719 & 0.019 & 0.0819 & 0.0013 & 0.0632 & 0.0014 \\
\hline 336 & 0.96 & 0.033 & 0.0788 & 0.0013 & 0.0886 & 0.0036 \\
\hline 337 & 0.9 & 0.038 & 0.0937 & 0.0015 & 0.0693 & 0.002 \\
\hline 338 & 0.7154 & 0.013 & 0.0779 & 0.0013 & 0.06659 & 0.00088 \\
\hline 339 & 0.657 & 0.014 & 0.078 & 0.0014 & 0.06128 & 0.00071 \\
\hline
\end{tabular}

\begin{tabular}{|c|c|c|c|c|c|c|}
\hline \multicolumn{6}{|c|}{ Isotopic ages (and $2 \sigma$ erros) } & \multirow{3}{*}{$\begin{array}{r}\text { Disc. } \\
\quad \%\end{array}$} \\
\hline $207 \mathrm{~Pb} /$ & & $206 \mathrm{~Pb} /$ & & 07Pb/ & & \\
\hline $235 \mathrm{U}$ & \pm & $238 \mathrm{U}$ & & 06/Pb & \pm & \\
\hline 594 & 22 & 560 & 13 & 750 & 110 & 94.28 \\
\hline 570.7 & 7.4 & 509.5 & 5.9 & 837 & 27 & 89.28 \\
\hline 616.5 & 9.3 & 601.8 & 7.1 & 657 & 29 & 97.62 \\
\hline 574 & 7.8 & 561.4 & 6 & 618 & 32 & 97.80 \\
\hline 611 & 12 & 579.1 & 6.6 & 737 & 47 & 94.78 \\
\hline 559 & 21 & 524.7 & 8.7 & 713 & 93 & 93.86 \\
\hline 549 & 12 & 507.3 & 7.6 & 715 & 46 & 92.40 \\
\hline 684 & 18 & 489.1 & 8 & 1389 & 83 & 71.51 \\
\hline 649 & 20 & 577.2 & 9.1 & 902 & 56 & 88.94 \\
\hline 548.6 & 7.4 & 483.5 & 7.7 & 837 & 26 & 88.13 \\
\hline 512.5 & 8.7 & 484.2 & 8.4 & 647 & 25 & 94.48 \\
\hline
\end{tabular}

15DL11, matrix of metaconglomerate, Group I (upper Ediacaran/lower Cambrian)

\begin{tabular}{|c|c|c|c|c|c|c|}
\hline \multicolumn{7}{|c|}{ \# Isotopic ratios (and $2 \sigma$ errors) } \\
\hline & $207 \mathrm{~Pb} /$ & & $206 \mathrm{~Pb} /$ & & $207 \mathrm{~Pb} /$ & \\
\hline & $235 \mathrm{U}$ & $\% \pm$ & $238 \mathrm{U}$ & $\% \pm$ & $206 \mathrm{~Pb}$ & $\% \pm$ \\
\hline 340 & 2.934 & 0.075 & 0.2094 & 0.0051 & 0.10135 & 0.0011 \\
\hline 341 & 2.21 & 0.23 & 0.082 & 0.0025 & 0.195 & 0.02 \\
\hline 342 & 1.163 & 0.085 & 0.0888 & 0.0021 & 0.096 & 0.0056 \\
\hline
\end{tabular}

\begin{tabular}{|c|c|c|c|c|c|c|}
\hline \multicolumn{6}{|c|}{ Isotopic ages (and $2 \sigma$ erros) } & \multirow[t]{2}{*}{ Disc. } \\
\hline $207 \mathrm{~Pb} /$ & & $206 \mathrm{~Pb} /$ & & $07 \mathrm{~Pb} /$ & & \\
\hline $235 \mathrm{U}$ & \pm & $238 \mathrm{U}$ & & $06 / \mathrm{Pb}$ & \pm & $\%$ \\
\hline 1389 & 19 & 1229 & 27 & 1648 & 21 & 88.48 \\
\hline 1169 & 71 & 508 & 15 & 2760 & 190 & 43.46 \\
\hline 779 & 39 & 548 & 12 & 1490 & 110 & 70.35 \\
\hline
\end{tabular}

15DL12, quartz sandstone ("El Hank quartzite"), Group IV (upper Cambrian)

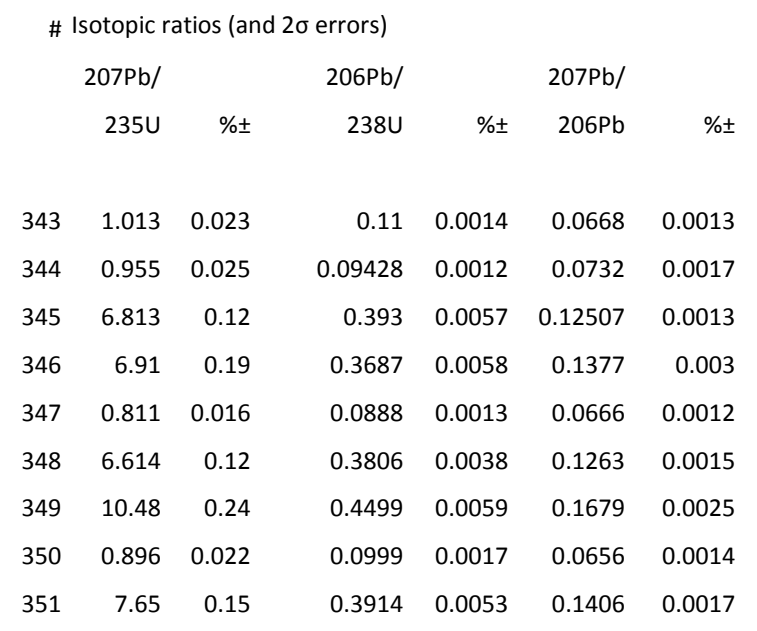

\begin{tabular}{|c|c|c|c|c|c|c|}
\hline \multicolumn{5}{|c|}{ Isotopic ages (and $2 \sigma$ erros) } & \multicolumn{2}{|r|}{ Disc. } \\
\hline 207Pb/ & & 206Pb/ & & $07 \mathrm{~Pb} /$ & & \\
\hline $235 \mathrm{U}$ & \pm & $238 U$ & & $06 / \mathrm{Pb}$ & \pm & $\%$ \\
\hline 680 & 13 & 580.8 & 6.9 & 1023 & 46 & 85.41 \\
\hline 1334 & 29 & 1139 & 28 & 1653 & 30 & 85.38 \\
\hline 2104 & 22 & 2023 & 27 & 2196 & 37 & 96.15 \\
\hline 602.8 & 8.7 & 548.6 & 7.6 & 834 & 38 & 91.01 \\
\hline 1991 & 16 & 1864 & 18 & 2129 & 20 & 93.62 \\
\hline 2630 & 18 & 2424 & 21 & 2786 & 26 & 92.17 \\
\hline 649 & 12 & 613.6 & 10 & 789 & 46 & 94.55 \\
\hline 1434 & 27 & 1145 & 26 & 1911 & 23 & 79.85 \\
\hline 1697.8 & 14 & 1251 & 23 & 2299 & 32 & 73.68 \\
\hline
\end{tabular}




$\begin{array}{rrrrrrr}352 & 4.326 & 0.074 & 0.2142 & 0.0044 & 0.1459 & 0.0027 \\ 353 & 1.853 & 0.034 & 0.1711 & 0.002 & 0.07891 & 0.00099 \\ 354 & 5.785 & 0.12 & 0.3458 & 0.004 & 0.1207 & 0.0018 \\ 355 & 6.61 & 0.18 & 0.3854 & 0.0091 & 0.1247 & 0.0024 \\ 356 & 1.596 & 0.067 & 0.0977 & 0.0017 & 0.1214 & 0.0054 \\ 357 & 0.96 & 0.036 & 0.09685 & 0.0011 & 0.0719 & 0.0025 \\ 358 & 2.144 & 0.047 & 0.07002 & 0.001 & 0.2203 & 0.0061 \\ 359 & 0.809 & 0.018 & 0.085 & 0.001 & 0.0688 & 0.0011 \\ 360 & 6.12 & 0.17 & 0.2569 & 0.0072 & 0.1726 & 0.0028 \\ 361 & 8.04 & 0.14 & 0.3705 & 0.005 & 0.15713 & 0.0014 \\ 362 & 6.11 & 0.15 & 0.3547 & 0.0055 & 0.1252 & 0.0025 \\ 363 & 9.138 & 0.14 & 0.4236 & 0.0045 & 0.1556 & 0.0017 \\ 364 & 0.959 & 0.033 & 0.09256 & 0.001 & 0.0748 & 0.0021 \\ 365 & 3.933 & 0.11 & 0.2255 & 0.0052 & 0.1269 & 0.0013 \\ 366 & 8.9 & 2.2 & 0.163 & 0.019 & 0.322 & 0.057 \\ 367 & 11.95 & 0.19 & 0.4898 & 0.0059 & 0.1771 & 0.0016\end{array}$

$\begin{array}{rrrrrrr}2317 & 20 & 2639 & 35 & 2046 & 23 & 113.90 \\ 1943 & 18 & 1914 & 19 & 1969 & 26 & 98.51 \\ 2064 & 23 & 2101 & 43 & 2022 & 34 & 101.79 \\ 965 & 25 & 601.1 & 9.8 & 1974 & 82 & 62.29 \\ 684 & 19 & 595.9 & 6.5 & 972 & 69 & 87.12 \\ 1162 & 15 & 436.2 & 6 & 2979 & 45 & 37.54 \\ 601.6 & 10 & 525.9 & 6.2 & 887 & 34 & 87.42 \\ 1990 & 24 & 1473 & 37 & 2583 & 26 & 74.02 \\ 2234 & 16 & 2031 & 23 & 2425 & 15 & 90.91 \\ 1990 & 22 & 1960 & 26 & 2031 & 35 & 98.49 \\ 2351.4 & 14 & 2282 & 22 & 2412 & 19 & 97.05 \\ 681 & 17 & 570.6 & 6.1 & 1057 & 58 & 83.79 \\ 1621 & 23 & 1310 & 27 & 2056 & 19 & 80.81 \\ 1910 & 270 & 960 & 110 & 2990 & 380 & 50.26 \\ 2580 & 16 & 2408 & 29 & 2729 & 15 & 93.33 \\ 663 & 14 & 629.8 & 8.3 & 773 & 43 & 94.99\end{array}$

